\title{
Simulation of Groundwater Flow in the Shallow Aquifer System of the Delmarva Peninsula, Maryland and Delaware
}

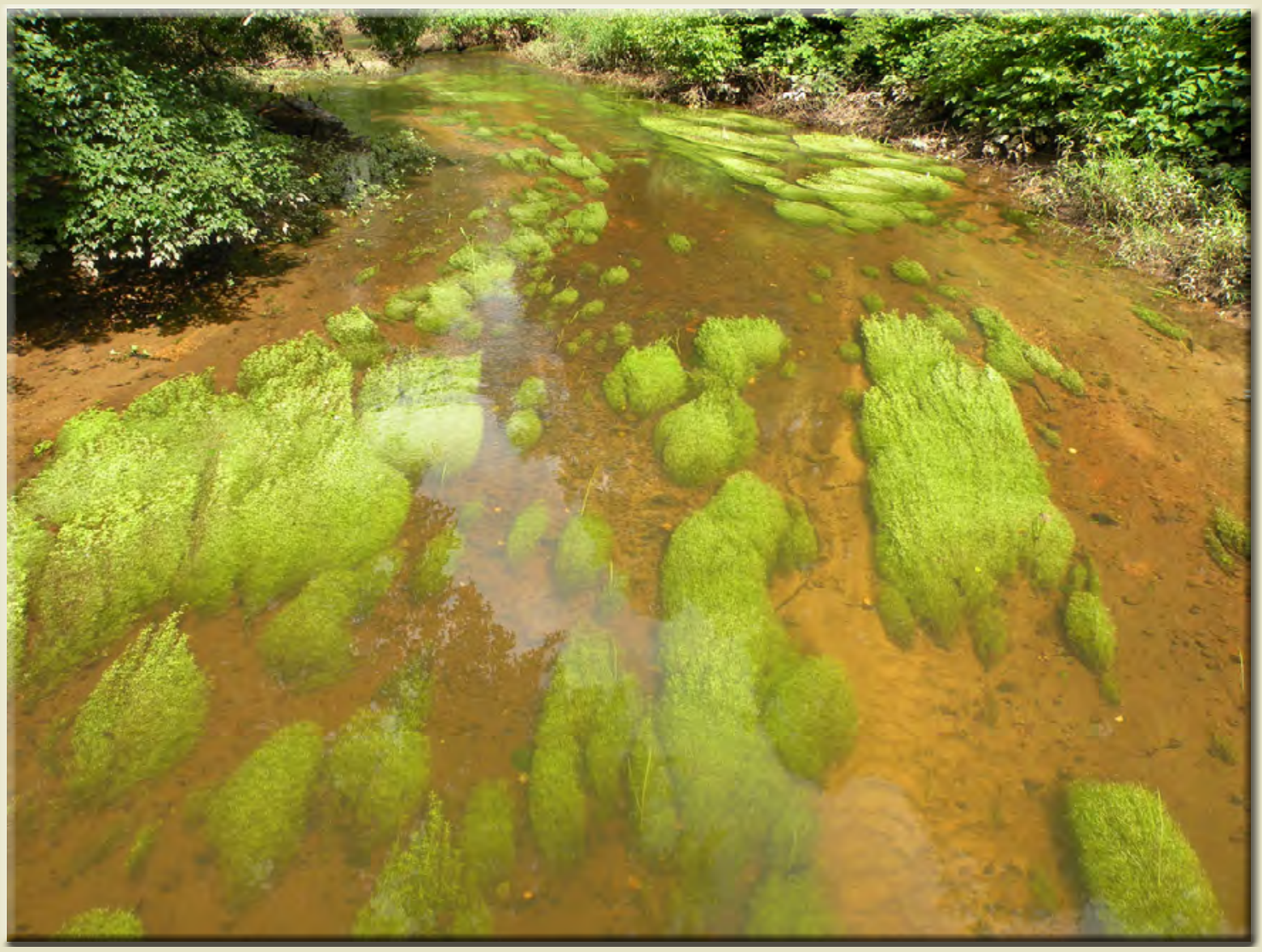

Open-File Report 2012-1140 
Cover. Flows in the Choptank River (shown) and other streams are used to calibrate the groundwater model. Photograph by Sharon Shahan, used with permission. 


\section{Simulation of Groundwater Flow in the Shallow Aquifer System of the Delmarva Peninsula, Maryland and Delaware}

By Ward E. Sanford, Jason P. Pope, David L. Selnick, and Ryan F. Stumvoll

Open-File Report 2012-1140 


\section{U.S. Department of the Interior \\ KEN SALAZAR, Secretary \\ U.S. Geological Survey \\ Marcia K. McNutt, Director}

\section{U.S. Geological Survey, Reston, Virginia: 2012}

For more information on the USGS — the Federal source for science about the Earth, its natural and living resources, natural hazards, and the environment, visit http://www.usgs.gov or call 1-888-ASK-USGS.

For an overview of USGS information products, including maps, imagery, and publications, visit http://www.usgs.gov/pubprod

To order this and other USGS information products, visit http://store.usgs.gov

Any use of trade, firm, or product names is for descriptive purposes only and does not imply endorsement by the U.S. Government.

Although this information product, for the most part, is in the public domain, it also may contain copyrighted materials as noted in the text. Permission to reproduce copyrighted items must be secured from the copyright owner.

Suggested citation:

Sanford, W.E., Pope, J.P., Selnick, D.L., and Stumvoll, R.F., 2012, Simulation of groundwater flow in the shallow aquifer system of the Delmarva Peninsula, Maryland and Delaware: U.S. Geological Survey Open-File Report 2012-1140, 58 p. 


\section{Contents}

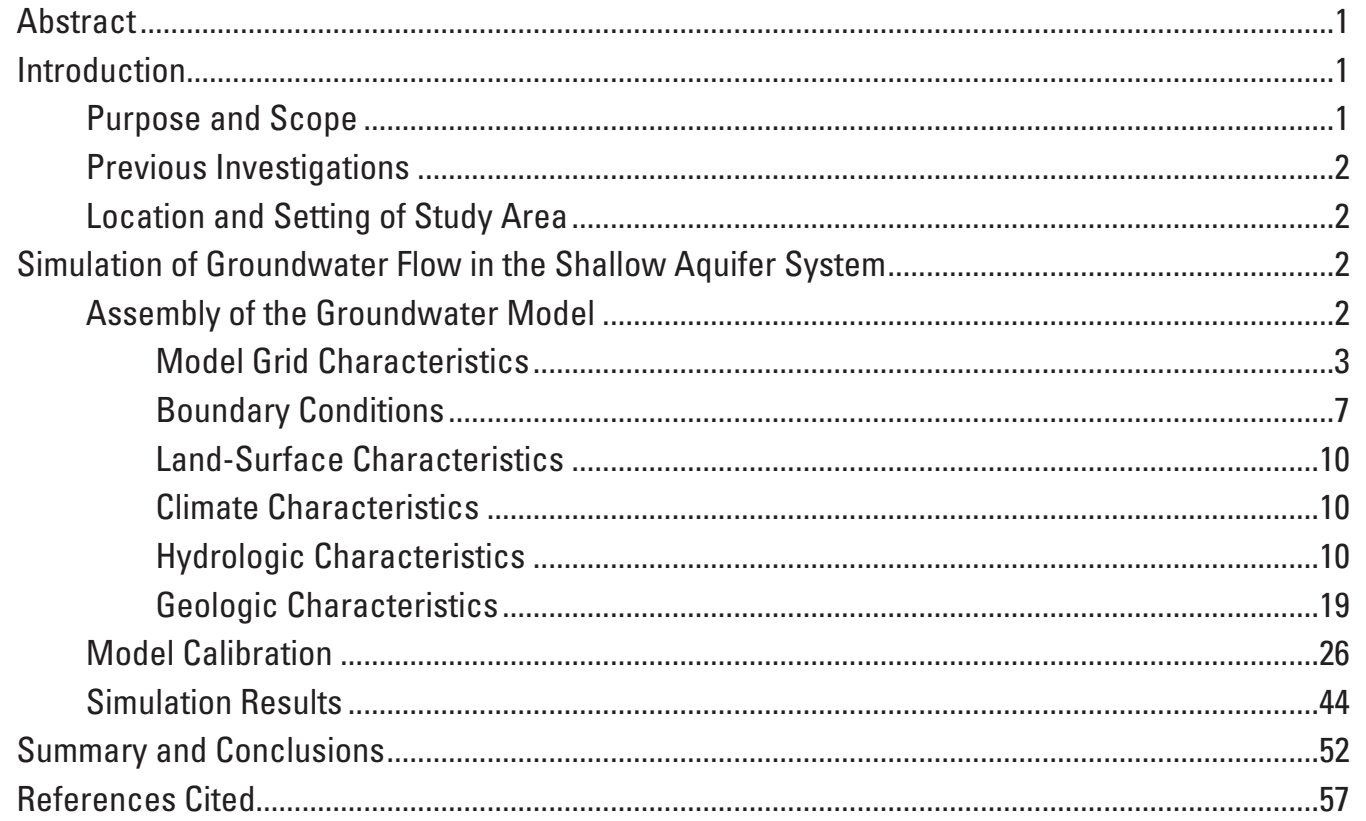

\section{Figures}

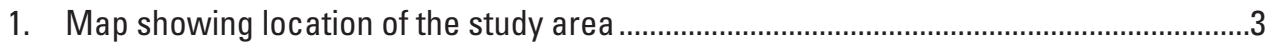

2. Map showing locations of counties, and state boundaries on the Delmarva Peninsula

3. Map showing region covered by the groundwater flow model including the active model area

4. Map showing location of watersheds by U.S. Geological Survey 8-digit hydrologic unit code.

5. Map showing elevation of land surface on the Delmarva Peninsula derived from light detection and ranging and bathymetry from National Oceanic and Atmospheric Administration National Geophysical Data Center, U.S. Coastal Relief Model

6. Map showing general land-cover types based on the U.S. Geological Survey 2001 National Land-Cover Dataset .

7. Map showing percentage of impervious surface based on the U.S. Geological Survey 2001 National Land-Cover Database.. . .11

8. Map showing texture of soils on the Delmarva Peninsula shown as percent sand .......12

9. Map showing texture of soils on the Delmarva Peninsula shown as percent clay ........13

10. Map showing mean annual precipitation on the Delmarva Peninsula from 1971 to 2000 based on the PRISM climate dataset.....

11. Map showing mean maximum daily temperature on the Delmarva Peninsula from 1971 to 2000 based on the PRISM climate dataset

12. Map showing mean minimum daily temperature on the Delmarva Peninsula from 1971 to 2000 based on the PRISM climate dataset 
13. Map showing mean annual temperature on the Delmarva Peninsula from 1971 to 2000 based on the PRISM climate dataset.

14. Map showing mean annual difference between the maximum and minimum daily temperature on the Delmarva Peninsula from 1971 to 2000 based on the PRISM climate dataset.

15. Map showing mean annual estimated evapotranspiration on the Delmarva Peninsula from 1971 to 2000 based on the climate regression equation of Sanford and others (2012).

16. Map showing mean-annual estimated surface runoff on the Delmarva Peninsula from 1971 to 2000 based on the regression equations of Sanford and others (2012) for the Coastal Plain physiographic province and the clay content of the soils.

17. Map showing mean annual estimated total runoff on the Delmarva Peninsula from 1971 to 2000 calculated by subtracting evapotranspiration from precipitation......22

18. Map showing mean annual estimated recharge on the Delmarva Peninsula from 1971 to 2000 based on the precipitation from the PRISM climate database and the climate and runoff regression equations of Sanford and others (2012)

19. Map showing bottom surface of the Cretaceous deposits on the Delmarva Peninsula relative to sea-level datum NGVD 29.

20. Map showing locations where various Cretaceous and Tertiary deposits outcrop at the land surface or subcrop beneath Quaternary deposits on the Delmarva Peninsula ....25

21. Cross-sectional view showing dipping of confined hydrogeologic units beneath the surficial aquifer along the line $B-B^{\prime}$

22. Map showing bottom surface of the Quaternary deposits on the Delmarva Peninsula relative to sea-level datum NGVD 29.

23. Map showing distribution of geologic units within layer 1 of the model grid .................28

24. Map showing distribution of geologic units within layer 2 of the model grid .................29

25. Map showing distribution of geologic units within layer 3 of the model grid ..................30

26. Map showing distribution of geologic units within layer 4 of the model grid ..................31

27. Map showing distribution of geologic units within layer 5 of the model grid ..................32

28. Map showing distribution of geologic units within layer 6 of the model grid .................33

29. Map showing distribution of geologic units within layer 7 of the model grid ..................34

30. Map showing locations of the 48 wells used for water-level observations .....................37

31. Map showing locations of U.S. Geological Survey stream gages and watersheds on the Delmarva Peninsula with real-time water data....................................................39

32. Map showing locations of the 23 well sites where samples were collected for groundwater-age observations.

33. Graphs showing observed versus simulated water levels, and simulated water levels versus the difference between the observed and simulated water levels ...........45

34. Map showing spatial distribution of errors in the simulated water-level observations ........... 46

35. Graphs showing observed versus simulated groundwater ages, and simulated ages versus the difference between the observed and simulated ages .........................47

36. Map showing spatial distribution of errors in the simulated age observations ..............48

37. Map showing the simulated water table on the Delmarva Peninsula represented by water levels in layer 1 of the model......................................................................................49

38. Map showing the simulated water levels in layer 7 of the model .....................................50

39. Map showing the simulated depth of the water table beneath the land surface ...........51

40. Map showing simulated net recharge across the Delmarva Peninsula calculated by subtracting the seepage discharge from the recharge. 
41. Map showing simulated groundwater age 80 feet below land surface in layer 4 of the model grid

42. Map showing simulated return time of groundwater travelling from the water table to its discharge location.

\section{Tables}

1. Observation wells and associated groundwater levels used to calibrate the groundwater model in this study...

2. Watersheds used to compare observed and simulated total runoff from the land

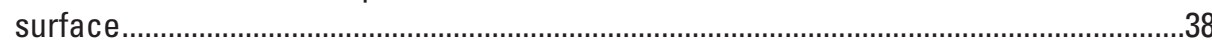

3. Observation wells and associated groundwater ages used for comparison with simulated groundwater ages in this study

4. Hydraulic conductivity values reported and specified or calibrated in the groundwater model in this study.....

5. Composite scaled sensitivities for hydraulic conductivity parameters in the groundwater model

6. Water budget terms in the groundwater model by model layer .......................................52

7. Water budget terms in the groundwater model by geologic unit.....................................53 


\section{Conversion Factors and Abbreviations}

Inch/Pound to SI

\begin{tabular}{lcl}
\hline & Multiply & \multicolumn{1}{c}{ By obtain } \\
\hline inch (in.) & Length & \\
inch (in.) & 2.54 & centimeter $(\mathrm{cm})$ \\
foot (ft) & 25.4 & millimeter $(\mathrm{mm})$ \\
mile (mi) & 0.3048 & meter $(\mathrm{m})$ \\
\hline & 1.609 & kilometer $(\mathrm{km})$ \\
\hline million gallons per day (Mgal/d) & Flow rate & \\
inch per year (in/yr) & 0.04381 & cubic meter per second $\left(\mathrm{m}^{3} / \mathrm{s}\right)$ \\
\hline & 25.4 & millimeter per year $(\mathrm{mm} / \mathrm{yr})$ \\
\hline foot per day (ft/d) & Hydraulic conductivity & \\
\hline
\end{tabular}

Temperature in degrees Fahrenheit $\left({ }^{\circ} \mathrm{F}\right)$ may be converted to degrees Celsius $\left({ }^{\circ} \mathrm{C}\right)$ as follows:

${ }^{\circ} \mathrm{C}=\left({ }^{\circ} \mathrm{F}-32\right) / 1.8$

Vertical coordinate information is referenced to the National Geodetic Vertical Datum of 1929 (NGVD 29).

Horizontal coordinate information is referenced to the North American Datum of 1983 (NAD 83).

Elevation, as used in this report, refers to distance above the vertical datum.

\section{Abbreviations}

CSS composite scaled sensitivity

ET evapotranspiration

RAM random access memory

USGS U.S. Geological Survey 


\title{
Simulation of Groundwater Flow in the Shallow Aquifer System of the Delmarva Peninsula, Maryland and Delaware
}

\author{
By Ward E. Sanford, Jason P. Pope, David L. Selnick, and Ryan F. Stumvoll
}

\begin{abstract}
Estimating future loadings of nitrogen to the Chesapeake Bay requires knowledge about the groundwater flow system and the traveltime of water and chemicals between recharge at the water table and the discharge to streams and directly to the bay. The Delmarva Peninsula has a relatively large proportion of its land devoted to agriculture and a large associated nitrogen load in groundwater that has the potential to enter the bay in discharging groundwater. To better understand the shallow aquifer system with respect to this loading and the traveltime to the bay, the U.S. Geological Survey constructed a steadystate groundwater flow model for the region. The model is based on estimates of recharge calculated using recently developed regression equations for evapotranspiration and surface runoff. The hydrogeologic framework incorporated into the model includes unconfined surficial aquifer sediments, as well as subcropping confined aquifers and confining beds down to 300 feet below land surface. The model was calibrated using 48 water-level measurements and 24 tracer-based ages from wells located across the peninsula. The resulting steady-state flow solution was used to estimate ages of water in the shallow aquifer system through the peninsula and the distribution and magnitude of groundwater traveltime from recharge at the water table to discharge in surface-water bodies (referred to as return time). Return times vary but are typically less than 10 years near local streams and greater than 100 years near the stream divides. The model can be used to calculate nitrate transport parameters in various local watersheds and predict future trends in nitrate loadings to Chesapeake Bay for different future nitrogen application scenarios.
\end{abstract}

\section{Introduction}

Groundwater plays a prominent role in the transport of nutrients to Chesapeake Bay. Over half of the freshwater entering the bay has travelled through the subsurface and discharged into streams beforehand (Phillips and Lindsey, 2003). The traveltime for groundwater is much longer than that of surface runoff, with the typical time of travel (return time or lag time) from recharge at the water table to stream discharge ranging from years to centuries. The variability in the return times creates difficulties in predicting the magnitude and timing of the effect of reducing nitrogen loading (in fertilizer, for example) at land surface on the resulting timing of nitrogen loading to the streams and the bay. To better predict the effects of nitrogen loading practices on the health of the bay, better estimates are needed for the distribution of groundwater return times to local streams across the Chesapeake Bay watershed. The purpose of this study is to obtain a map of groundwater return times that can be used in estimating and forecasting nitrogen loading to the Chesapeake Bay. The best type of tool currently available to estimate groundwater return times is a groundwater simulation model calibrated using environmental tracers. A series of such models is currently being developed by the U.S. Geological Survey (USGS), as part of its Priority Ecosystems Science Initiative, for major sections of the Chesapeake Bay watershed. The Delmarva Peninsula is the first section for which this type of groundwater model is being constructed. The peninsula was chosen as the first study site because a large percentage of its area is devoted to agriculture and is near the bay; it was also chosen because the surficial aquifer is composed of porous sediments of the Atlantic Coastal Plain, the effect of which is to increase the length and effect impact of the groundwater lag time relative to that in fractured rock terrains west and north of the plain. The return times obtained from the current modeling effort can be used to estimate the timing of nitrogen delivery to Chesapeake Bay for different regions, and help environmental managers assess current and future nitrogen application practices.

\section{Purpose and Scope}

The purpose of this report is to describe the construction a groundwater model of the shallow aquifer system of the Delmarva Peninsula that can be used to calculate ranges of groundwater return times from recharge areas to streams. The aquifer system simulated by the model is the surficial aquifer 
and subcropping confined aquifers and confining units down to 300 feet (ft) below land surface. The model grid, boundary conditions, and the hydrologic and geologic factors used to construct this model are all described herein. The grid was constructed with a horizontal discretization of $500 \mathrm{ft}$ over the entire peninsula (the Virginia section of the southernmost peninsula was mostly excluded) in order to incorporate details of the local flow system. Because the model was designed to study the transport of nitrogen (mostly as nitrate) from the land surface to streams, only the shallow flow system (approximately the top $300 \mathrm{ft}$ ) was included in the model. Much of the groundwater used for public supply on the peninsula is extracted from deeper confined aquifers, but the impact of those withdrawals on the deeper groundwater system is beyond the purpose of this study, and therefore, the extent of this model. Also described herein are the development and initial results of the model in terms of the simulated steady-state water table, groundwater ages, and return-time distributions.

\section{Previous Investigations}

To date, no comprehensive groundwater model has been constructed that covers the majority of the Delmarva Peninsula. During the 1980s and 1990s, the USGS constructed a regional model of the Atlantic Coastal Plain (Leahy and Martin, 1993; Fleck and Vroblesky, 1996), but the Delmarva Peninsula was only represented in a very rudimentary manner because of the relatively large discretization used. In addition, the shallow unconfined aquifer that contributes most of the flow to the local streams was represented only as a constanthead boundary in that model. Groundwater models of the Coastal Plain aquifers in other states (North Carolina and Virginia) have been constructed recently (Heywood and Pope, 2009), but no equivalent model has been constructed in Maryland or Delaware, and as with previous work on the Delmarva Peninsula, the focus of the other models was the deeper aquifers that are used for most of the water-supply withdrawals. The flow system of the surficial aquifer on the peninsula and its role in nutrient transport have been studied by use of environmental tracers (Dunkle and others, 1993; Bohlke and Denver, 1995) and local representative cross-sectional flow modeling (Reilly and others, 1994). The hydrogeologic characterization of the peninsula has also been described recently (Ator and others, 2005), and this characterization was used to estimate variations in recharge in the Coastal Plain sediments of Virginia (Sanford and others, 2012). The southern portion of the Delmarva Peninsula that lies in Virginia was included in a groundwater model that also addressed the potential for saltwater intrusion (Sanford and others, 2009), and because this section has already been simulated, it was mostly excluded from the current study; this excluded portion of the peninsula is referred to hereafter as the "Virginia section." The Virginia Delmarva model was also used for a preliminary estimate of nitrate delivery to Chesapeake Bay (Sanford and Pope, 2007).

\section{Location and Setting of Study Area}

The Delmarva Peninsula is that portion of land bordered by Chesapeake Bay, Delaware Bay, and the Atlantic Ocean (fig. 1). The groundwater model was constructed to include the entire peninsula except the Virginia section. Excluding the Virginia section also allowed for a more efficient use of computer storage in that large portions of areas outside the peninsula did not have to be included in the model. Counties in the study area include Kent, Queen Anne's, Talbot, Caroline, Dorchester, Wicomico, Somerset, Worcester, and part of Cecil in Maryland; Sussex, Kent and part of New Castle in Delaware; and a small part of northern Accomack County in Virginia (fig. 2). Although some areas of Maryland west of the bay and areas of New Jersey are included in the model grid, they are not included in the active area of the model where groundwater flow is simulated (fig. 3).

\section{Simulation of Groundwater Flow in the Shallow Aquifer System}

As noted earlier, the focus of the model in this study is to calculate the distribution of groundwater return times present in the shallow aquifer system across the majority of the Delmarva Peninsula.

\section{Assembly of the Groundwater Model}

The major watersheds within the peninsula can be divided into two groups - those that drain westward into Chesapeake Bay and those that drain eastward into Delaware Bay or the Atlantic Ocean (fig. 4). The watershed divide between the two is oriented north-south through Delaware and is relatively close to the coastal bays of Maryland, resulting in about two-thirds of the peninsula draining into Chesapeake Bay (fig. 4). Although future use of the model is to focus on using the groundwater return times to estimate the timing of nutrient transport to Chesapeake Bay, the entire peninsula was included in the model in case future studies of nitrogen transport in the eastern watersheds are initiated. The objective of creating the model was to provide the ability to calculate distributions of groundwater return times within individual watersheds of interest, and because seasonal variations in flow and stresses do not typically cause any substantial variations in the overall distribution of these times (Reilly and Pollock, 1996), a steady-state flow simulation was deemed sufficient for the return-time calculations. In addition, although the volumes of groundwater extracted for human and agricultural use from the shallow system are substantial, they are relatively small compared to the overall recharge and discharge fluxes in the aquifer; therefore, withdrawals of water by pumping were excluded from the simulation. For example, the total pumping of groundwater from the model area in 2005 was less than 60 million gallons per day (Mgal/d) (Kenny and 


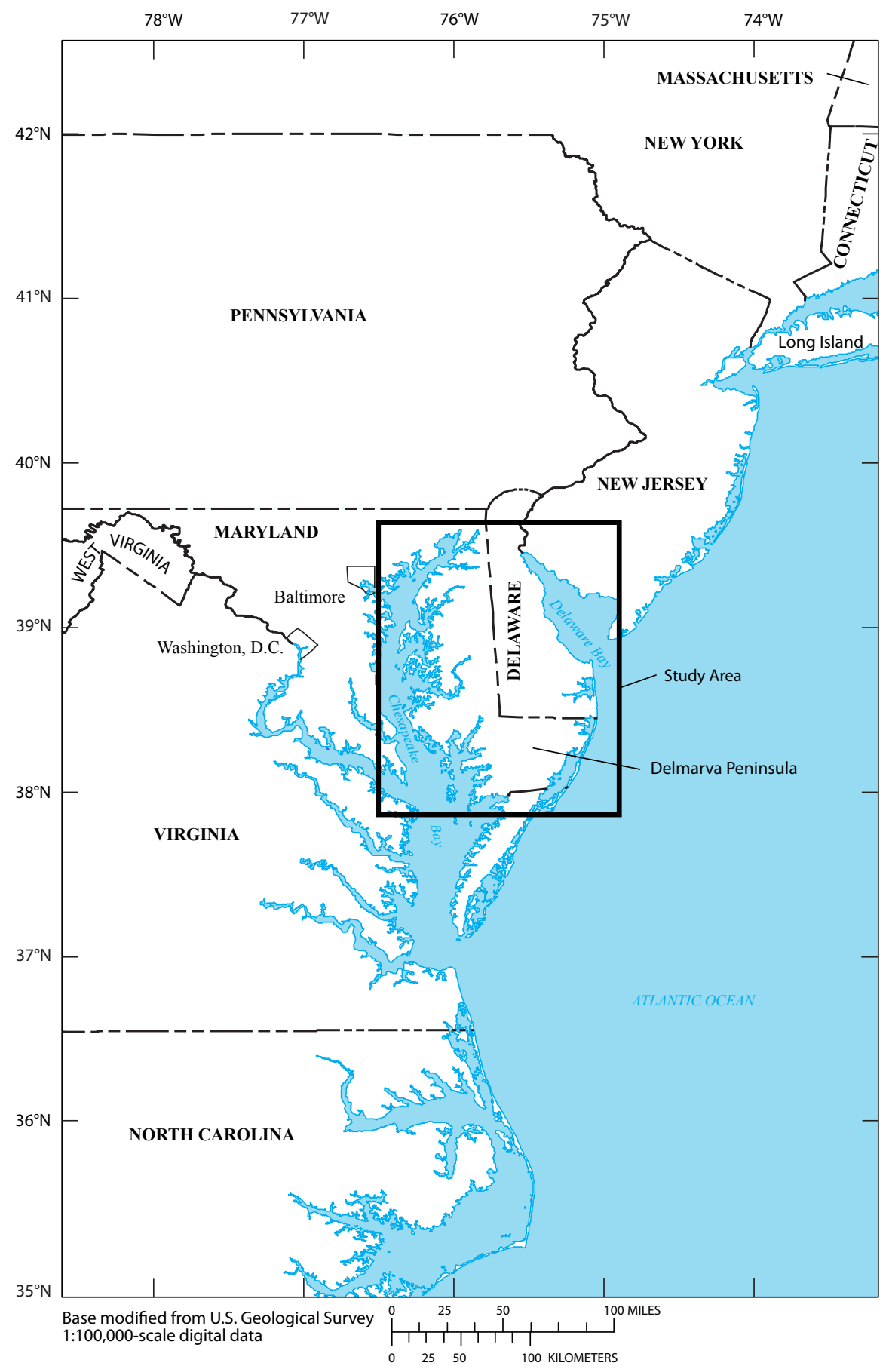

Figure 1. Location of the study area.

others, 2009), but the total mean annual recharge to the area is in excess of 3,300 Mgal/d (see section Simulation Results). Likewise, water withdrawals from the deeper confined aquifers are substantial quantities themselves, as they are derived partly from storage losses as the aquifers and confining units compress. Consequently, the remaining flux downward from the shallow aquifers is small relative to the natural recharge and discharge to the streams. The simulation of only steady-state, natural flow in the shallow system substantially reduced the amount of work required to construct and calibrate the model, yet was more than adequate to meet the objective of the study.

\section{Model Grid Characteristics}

A major requirement of the model development was to obtain the distributions of groundwater traveltimes for various subwatersheds within the peninsula, and thus, a discretization 


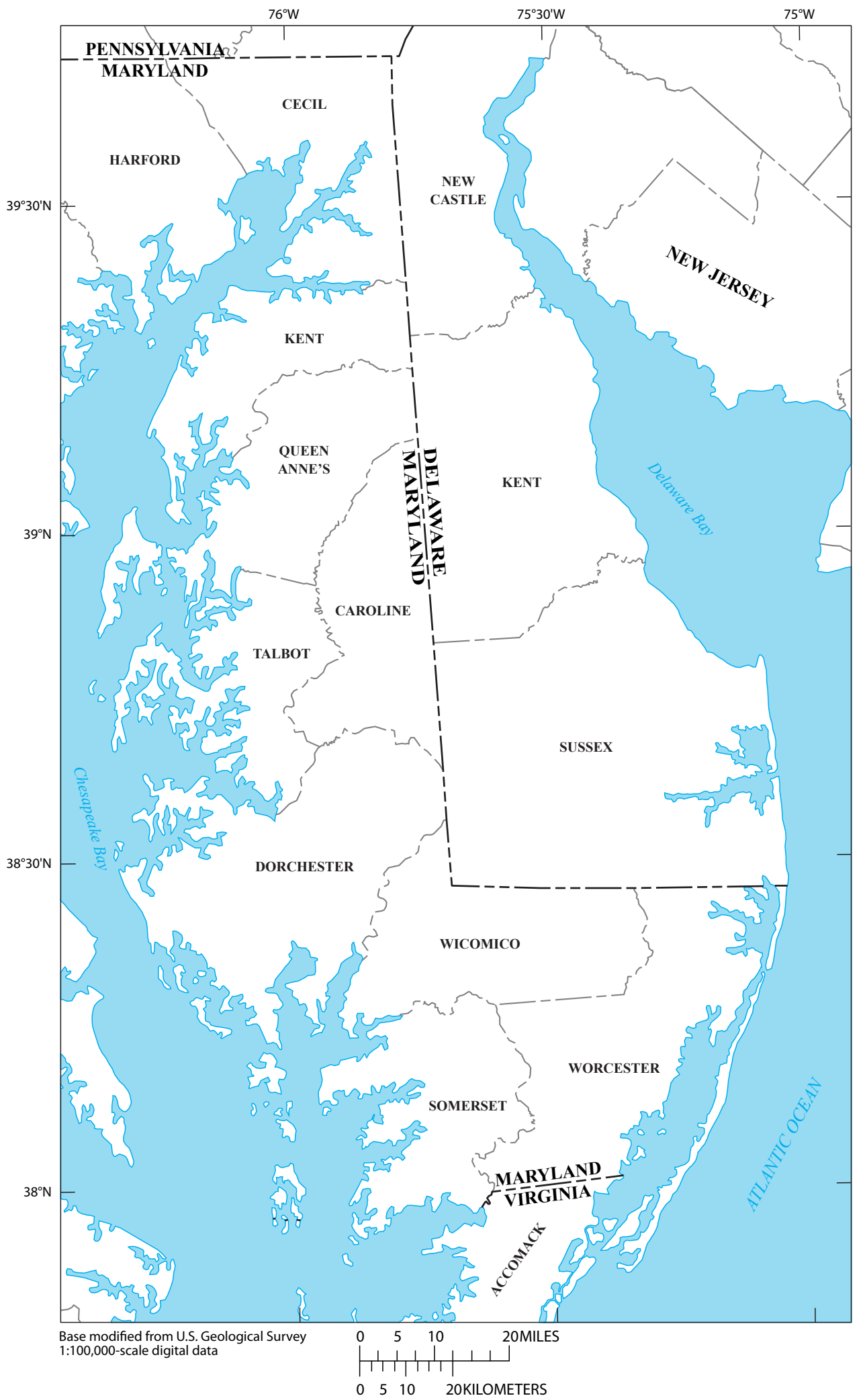

Figure 2. Locations of counties, and state boundaries on the Delmarva Peninsula. 


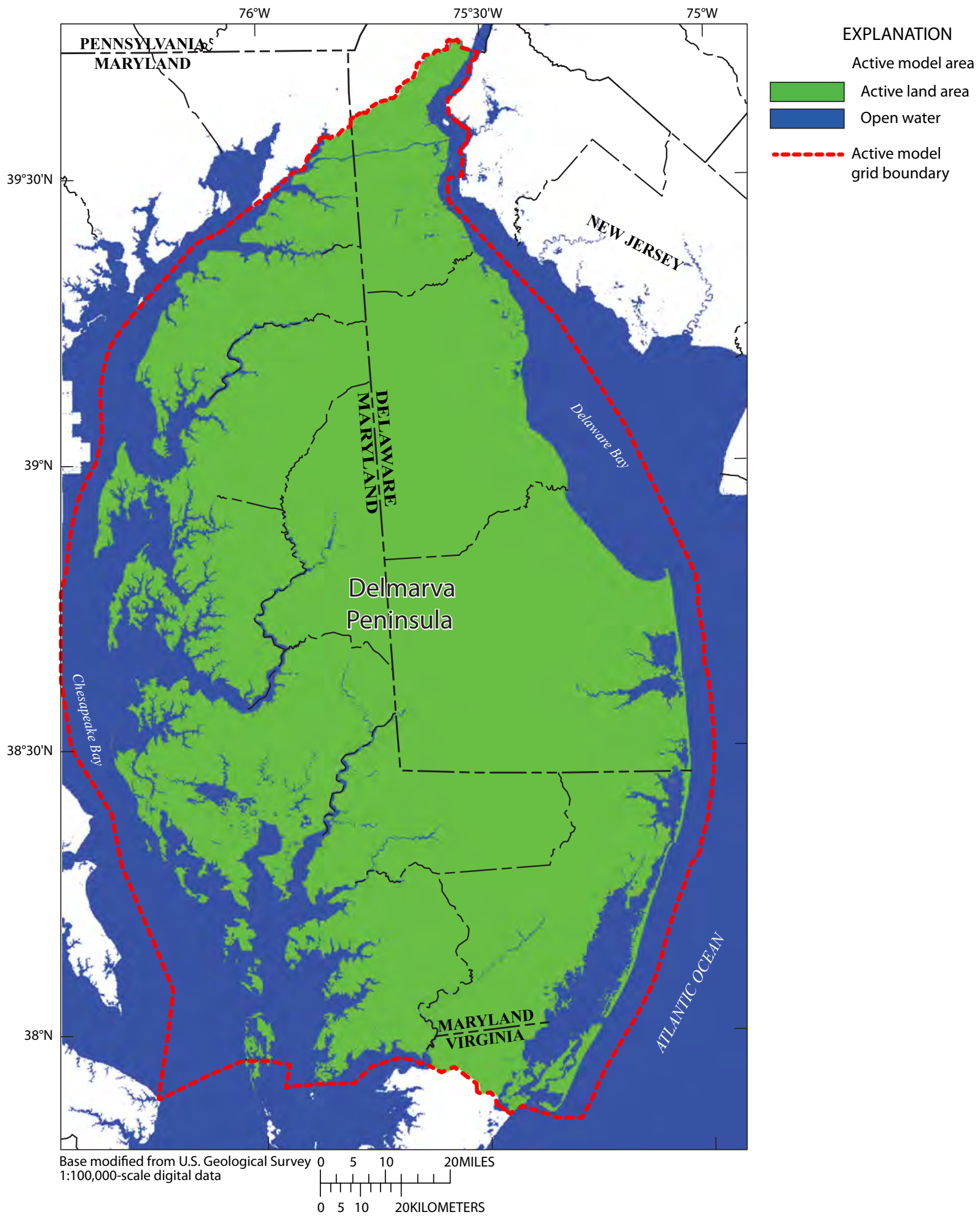

Figure 3. Region covered by the groundwater flow model ( 875 columns by 1,435 rows) including the active model area. 


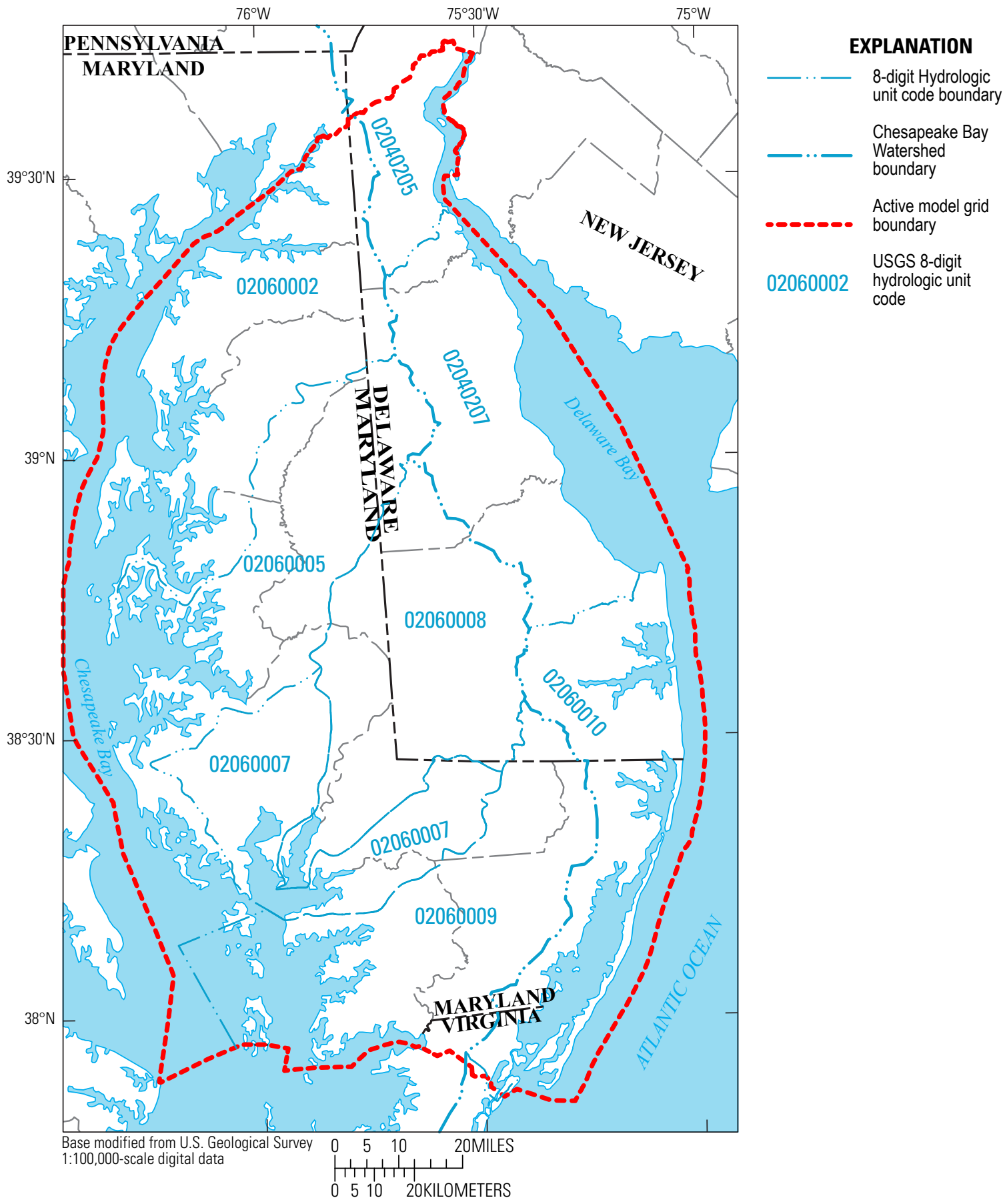

Figure 4. Location of watersheds by U.S. Geological Survey 8-digit hydrologic unit code (HUC-8). 
was required that was fine enough to give a good resolution of flow paths, even for watersheds as small as several square miles. In accordance with this criterion, a uniform horizontal discretization of $500 \mathrm{ft}$ was used across the entire model area. Coverage of the entire model area at this spatial discretization yielded 1,435 rows and 875 columns in the model grid. The USGS MODFLOW-2005 simulation code (Harbaugh, 2005), a three-dimensional finite-difference groundwater flow model, was used to simulate the flow system.

Although much of the groundwater flow in the shallow system is local flow to streams, a vertical discretization was required that would still allow characterization of the vertical aspect of the flow. This aspect included vertical flow near streams and the variable nature of the Coastal Plain strata (including permeable aquifers sediments and fine-grained confining units) that dip toward the southeast and subcrop beneath a layer of overlying Quaternary sediments that are commonly breached in the stream valleys. To achieve this, seven layers were used in the model that progressively increase in thickness with depth. The uppermost layer, layer 1, is $10 \mathrm{ft}$ thick and has a top elevation equal to the land surface elevation throughout the model area. The remaining six layers, progressing downward, are $20,30,40,50,60$, and $90 \mathrm{ft}$ thick, for a total model thickness of $300 \mathrm{ft}$. Although the model grid extends to $300 \mathrm{ft}$ below land surface, the fine-grained confining beds form a relative barrier to any substantial vertical flow penetrating this deep in many areas of the peninsula. The model grid consists of nearly 8.8 million cells, of which about 5.5 million ( 62 percent) are active. The model requires close to 4 gigabytes of random access memory (RAM) to run on a personal computer, as well as a 64-bit operating system that can appropriate 4 or more gigabytes of RAM.

In general, the water table is relatively close to the land surface across the peninsula, although it is more than $60 \mathrm{ft}$ below land surface in a few places. Consequently, the top few model layers are dry in a number of locations, creating a nonlinear flow condition in which the aquifer transmissivity is dependent upon the elevation of the water table, and vice versa. This strong nonlinearity, along with a variability of up to five orders of magnitude in hydraulic conductivity between certain units, created severe difficulties in achieving numerical convergence using the standard numerical solvers found in MODFLOW. The Newton version of MODFLOW (Niswonger and others, 2011) was used to overcome this difficulty during the calibration and achieve the final steady-state flow solution. The processing time required to solve the steady-state solution with MODFLOW-NWT is about 10 minutes on a T7500 Dell Precision with 3.33 gigahertz $(\mathrm{GHz})$ Intel Xeon processors.

\section{Boundary Conditions}

Simulation of any groundwater flow system requires appropriate boundary conditions. The active model area (fig. 3) in this study includes both land and areas of open water in the Chesapeake and Delaware Bays and the Atlantic Ocean. The model cells that are below sea level in these water bodies are treated with a general-head boundary condition. The conductance term was set to a sufficiently high value $\left(50,000 \mathrm{ft}^{-1}\right)$ so that the water-sediment interface would behave similarly to a constant-head boundary. This is equivalent to a hydraulic conductivity in the each cell of 10 feet per day (ft/d) connecting the center of the $10-\mathrm{ft}$ thick cell with the top boundary of the cell at which the external head is located. This external head is equivalent to sea level (defined as zero), but is also adjusted to account for the additional pressure head created by the excess density of the salt in the column of water above the cell. For this calculation, a salinity value equivalent to that of standard ocean water was used in the Delaware Bay and Atlantic Ocean, and values that were representative of the mean Chesapeake Bay salinity distribution were used beneath Chesapeake Bay. The effect of the excess salt head in these regions was minimal because of the relatively shallow surface-water depths close to shore (fig. 5) and the shallow extent of the groundwater flow system relative to the horizontal distances involved. The majority of the flow along the Chesapeake Bay shoreline was usually restricted to the top few model layers and was relatively small in magnitude because much of the nearshore sediment is relatively fine-grained. The minor perceived effect of density variation justified the constantdensity assumption, as well as the use of MODFLOW rather than a more computationally intensive variable-density code, such as SEAWAT (Langevin and others, 2003). The latter code was used, for example, in the Virginia Eastern Shore model (Sanford and others, 2009), where the objective was to track saltwater intrusion in deeper confined aquifers.

The land surface is treated in the model as a combination of a recharge and seepage-face boundary as described in Sanford (2002). This combination of boundary conditions is very effective where relief is relatively low and the water table is relatively shallow, and it allows the model to calculate the magnitude and distribution of discharge within the stream valleys. With this approach, recharge is applied to all cells above sea level. The recharge values applied were estimated using the same water-balance method applied recently to the Coastal Plain of Virginia (Sanford and others, 2012); more detail about these values is provided later in this report. A "drain" boundary condition, as defined in drain package of MODFLOW, is also assigned to every cell above sea level to represent a seepage face. In this approach, the elevation of the land surface (fig. 5) is commonly used as the elevation of the drain. On the Delmarva Peninsula, however, drains have been installed in much of the agricultural land where the water table is near the land surface. In riparian areas, evapotranspiration from the water table keeps the water table near the bottom of the root zone. Although including drain locations in the model was beyond the scope of this study, the model-drain elevations at each cell were adjusted downward to represent these conditions. Land-cover types on the peninsula were also included in the model grid (fig. 6). For each cell that represented agricultural land cover, the drain elevation for the cell was set to $6 \mathrm{ft}$ below the land surface. Where forest was present, the 


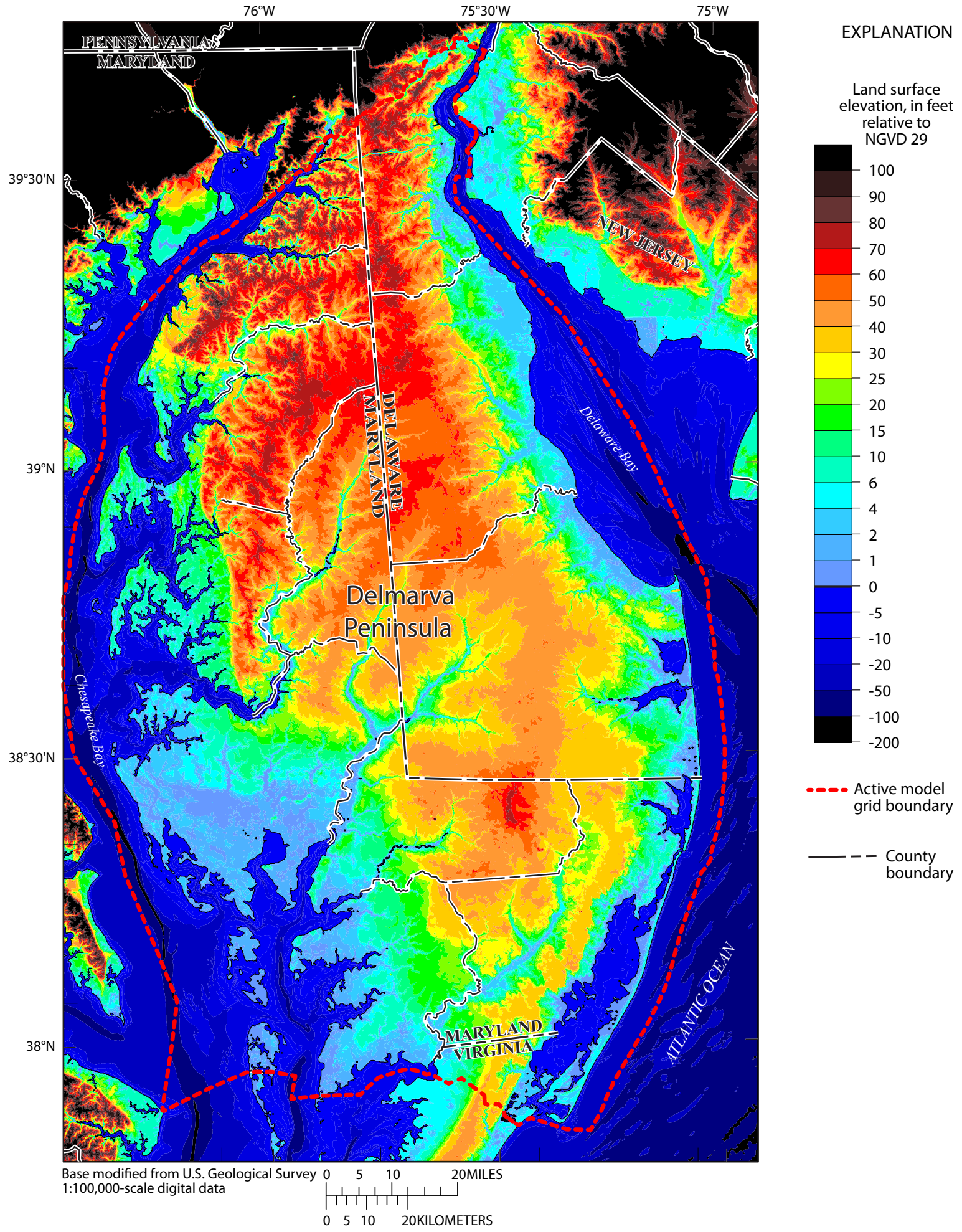

Figure 5. Elevation of land surface on the Delmarva Peninsula derived from light detection and ranging (LIDAR) (Roger Barlow, U.S. Geological Survey, unpub. data, 2010), and bathymetry from National Oceanic and Atmospheric Administration National Geophysical Data Center, U.S. Coastal Relief Model. Retrieved July 2007 from http://www.ngdc.noaa.gov/mgg/coastal/crm.html. 


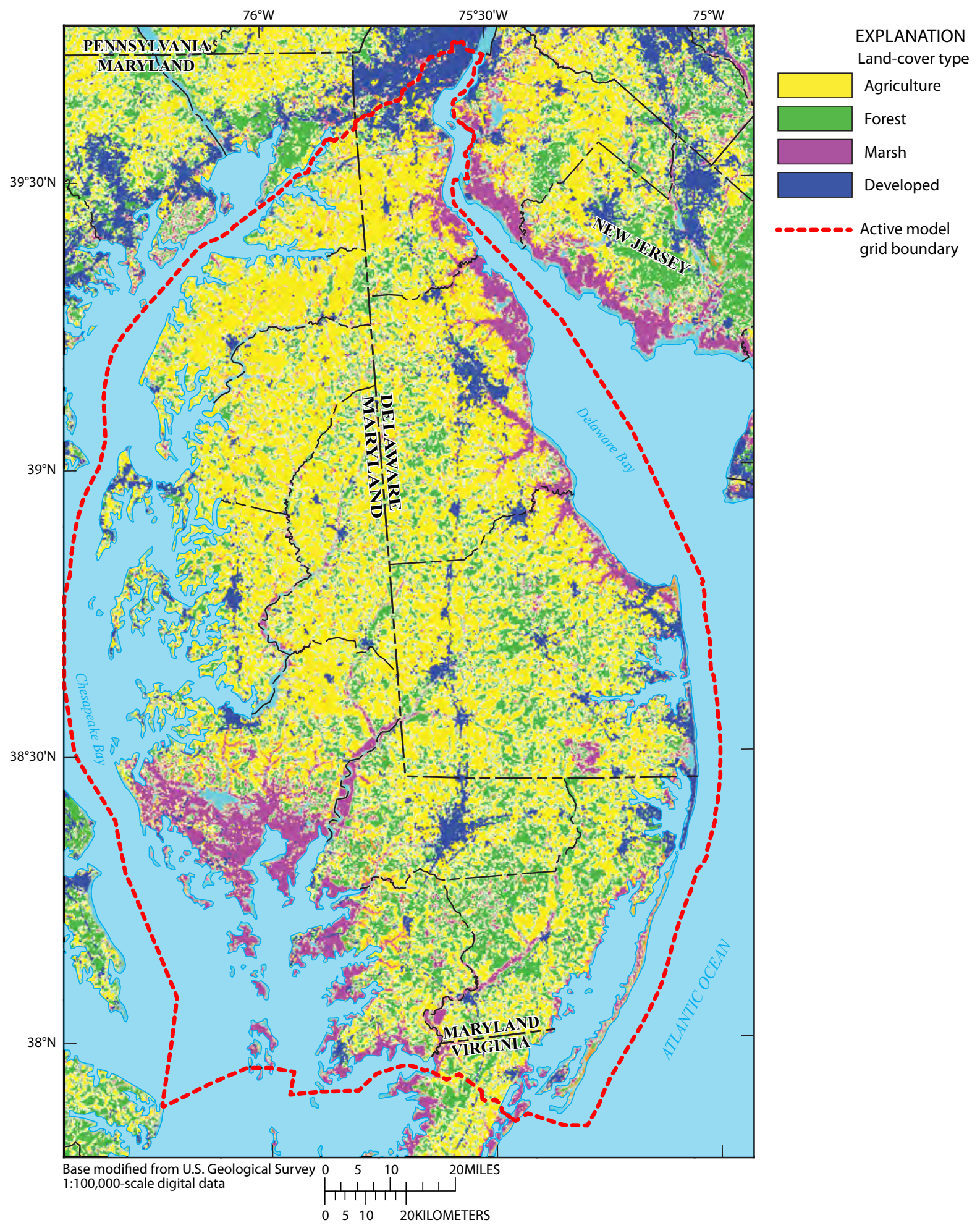

Figure 6. General land-cover types based on the U.S. Geological Survey 2001 National Land-Cover Dataset. Data retrieved August 2007 from http://landcover.usgs.gov/natllandcover.php. 
elevation was set at $3.5 \mathrm{ft}$ below the surface, and where urban development or marsh was present, the elevation was set to $2 \mathrm{ft}$ below the surface. These values were chosen to represent the typical depths of agricultural drains, forest root systems, and urban grass or marsh root systems, respectively. The values only made a difference in areas where the water table was close to the land surface, typically near streams. If the water level in a given cell is calculated to be above the drain elevation, then discharge is calculated by the model automatically; if the water level is below drain elevation, then discharge is zero. The conductance of the drain is specified as a value equal to the area of the cell multiplied by the hydraulic conductivity of the local cell material and divided by the distance between the land surface and the center of the cell in layer $1(5 \mathrm{ft})$. Although cells having discharge were mostly in the stream valleys, the hydraulic conductivity of the streambeds was not assumed to differ from that of the local aquifer material. Riparian evapotranspiration is not calculated explicitly in the model, but its flux, which is much smaller than the direct seepage discharge to the streams, is an implicit part of the drain discharge.

The bottom of the model grid is treated as a no-flow boundary. The cells representing the confining units in the system, however, are assigned a hydraulic conductivity value of $0.001 \mathrm{ft} / \mathrm{d}$, which is at least three orders of magnitude lower than that of the aquifer cells. Thus, in many parts of the peninsula, the effective bottom of the flow system is the top of the local confining layer and much shallower than the $300-\mathrm{ft}$ depth of the bottom of the model.

\section{Land-Surface Characteristics}

Because the top of the water table is relatively close to the land surface across the Delmarva Peninsula, land-surface characteristics strongly affect the shallow groundwater flow system. The topography of the peninsula is relatively low in relief (fig. 5), with the highest elevation being $93 \mathrm{ft}$ above NGVD 29 in the northeastern region. Coastal areas, however, are mostly within a few feet of NGVD 29. The land cover (fig. 6) is mostly agricultural, but there are also substantial areas of forest, swamp, and urban or suburban development. The developed areas create impervious surfaces that alter the runoff and recharge potentials that affect the shallow groundwater flow system. A map showing percentages of impervious surface (fig. 7) compiled from 2001 data (Homer and others, 2004) illustrates that areas with highly impervious surfaces are concentrated around the towns and small cities. Soil texture was an important factor in recent estimates of recharge on the Coastal Plain of Virginia and Maryland (Sanford and others, 2012), and it was used to estimate recharge for this model. Surficial sediments range in composition from clays to sands. Maps of the percentages of sand (fig. 8) and clay (fig. 9) in the soil indicated sand content was greatest in the eastern and central portions of the peninsula and clay content was greatest along the margins, especially in the low-lying tidal regions along Chesapeake Bay.

\section{Climate Characteristics}

Climatic conditions on the peninsula influence the shallow groundwater flow system through precipitation, which affects the recharge rate, and the air temperature, which affects the evapotranspiration rate. A recent study by Sanford and others (2012) used climatic factors to help estimate evapotranspiration and subsequent recharge in Virginia. The factors of importance for calculating long-term mean annual evapotranspiration (ET) and recharge were mean annual precipitation and mean-annual daily maximum and minimum temperatures. Because the groundwater model in the current study is a steady-state model that does not incorporate temporal variations in precipitation and recharge, the long-term average ET and recharge regression equations developed for the Virginia study were also applied to this study. All climate data were obtained from the PRISM climate dataset (Daly and others, 2008) and represented average values from 1971 to 2000 . Mean annual precipitation during the period (fig. 10) did not vary greatly across the peninsula, and ranged from 41 inches in northernmost Virginia at the southern end of the Delmarva Peninsula to over 45 inches in portions of Delaware and southeastern Maryland. The mean maximum daily temperature ranged from less than $65^{\circ} \mathrm{F}$ in the northernmost peninsula to more than $67^{\circ} \mathrm{F}$ in south-central portions of Maryland (fig. 11). The mean minimum daily temperature ranged from less than $44^{\circ} \mathrm{F}$ in the northernmost peninsula to $49^{\circ} \mathrm{F}$ in the southernmost coastal regions of the study area (fig. 12). The mean daily temperature ranged from $54^{\circ} \mathrm{F}$ in the northernmost peninsula to over $57^{\circ} \mathrm{F}$ in the southernmost section (fig. 13). The ET rate, as estimated by Sanford and others (2012), was a function not only of the mean annual daily temperature, but also of the difference between the mean annual daily maximum and minimum temperatures. Daily differences in temperature are smallest near the coast where humidity is greater, and as a result, solar radiation and ET are less (fig. 14). The greatest range in daily temperature on the peninsula was about $21^{\circ} \mathrm{F}$ in the central region, and the lowest was less than $17^{\circ} \mathrm{F}$ along the coastlines of Maryland and Virginia.

\section{Hydrologic Characteristics}

The climatic factors and their spatial distributions described in the preceding section were used to estimate ET in the following regression equation from Sanford and others (2012):

$$
E T=0.370 P+0.957 T_{\max }-0.383 T_{\min }-34.277
$$

where

$$
\begin{gathered}
E T \quad \text { is the evapotranspiration rate, in inches per } \\
\text { year; } \\
P \quad \text { is the precipitation rate, in inches per year; } \\
T_{\max } \quad \begin{array}{l}
\text { is the mean maximum daily temperature, in } \\
\text { degrees Fahrenheit; and }
\end{array} \\
T_{\min } \quad \begin{array}{l}
\text { is the mean minimum daily temperature, in } \\
\text { degrees Fahrenheit. }
\end{array}
\end{gathered}
$$




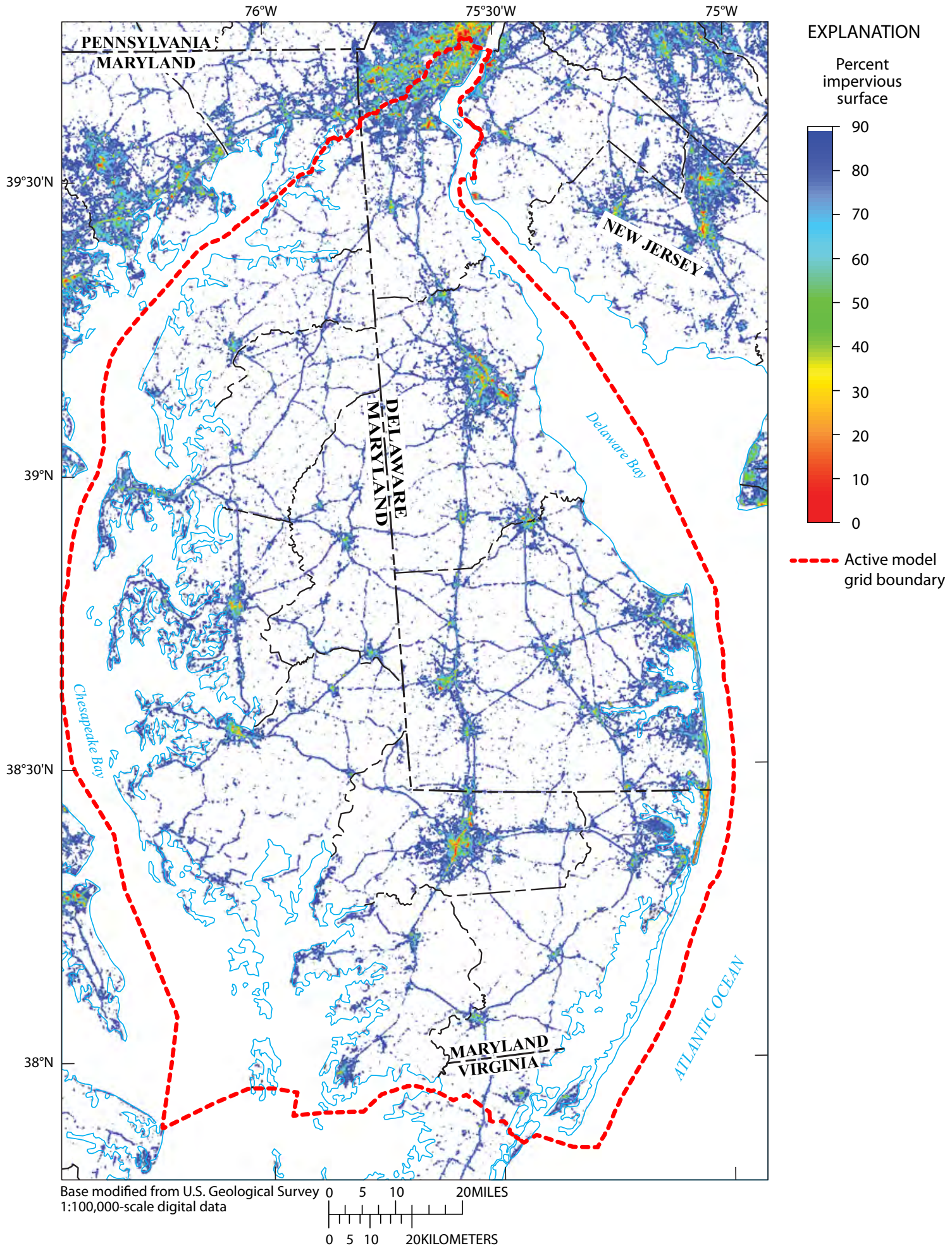

Figure 7. Percentage of impervious surface based on the U.S. Geological Survey 2001 National Land-Cover Database (Homer and others, 2004). 


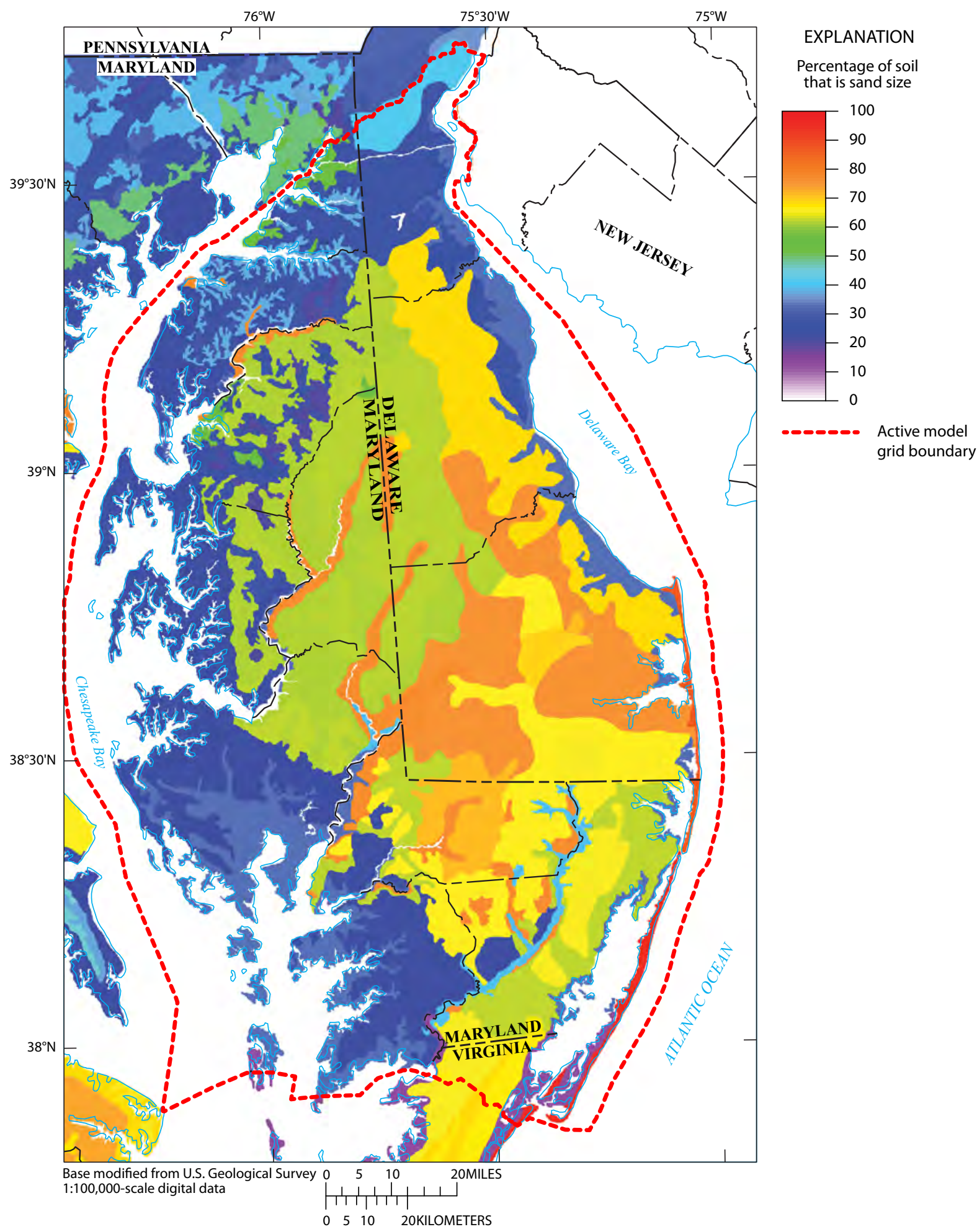

Figure 8. Texture of soils on the Delmarva Peninsula shown as percent sand. Data retrieved September 2007 from http://soildatamart.nrcs.usda.gov. 


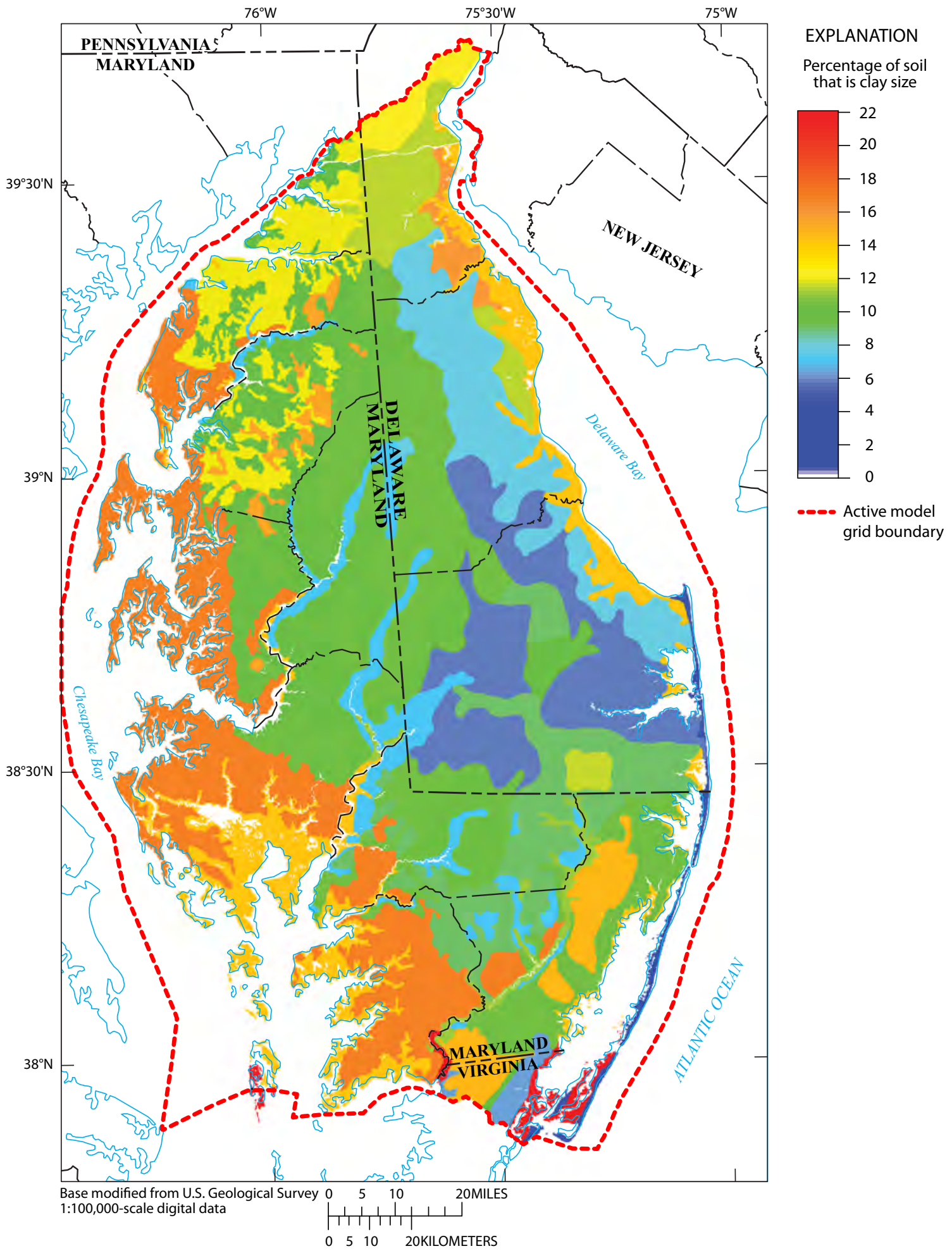

Figure 9. Texture of soils on the Delmarva Peninsula shown as percent clay. Data retrieved September 2007 from http://soildatamart.nrcs.usda.gov. 


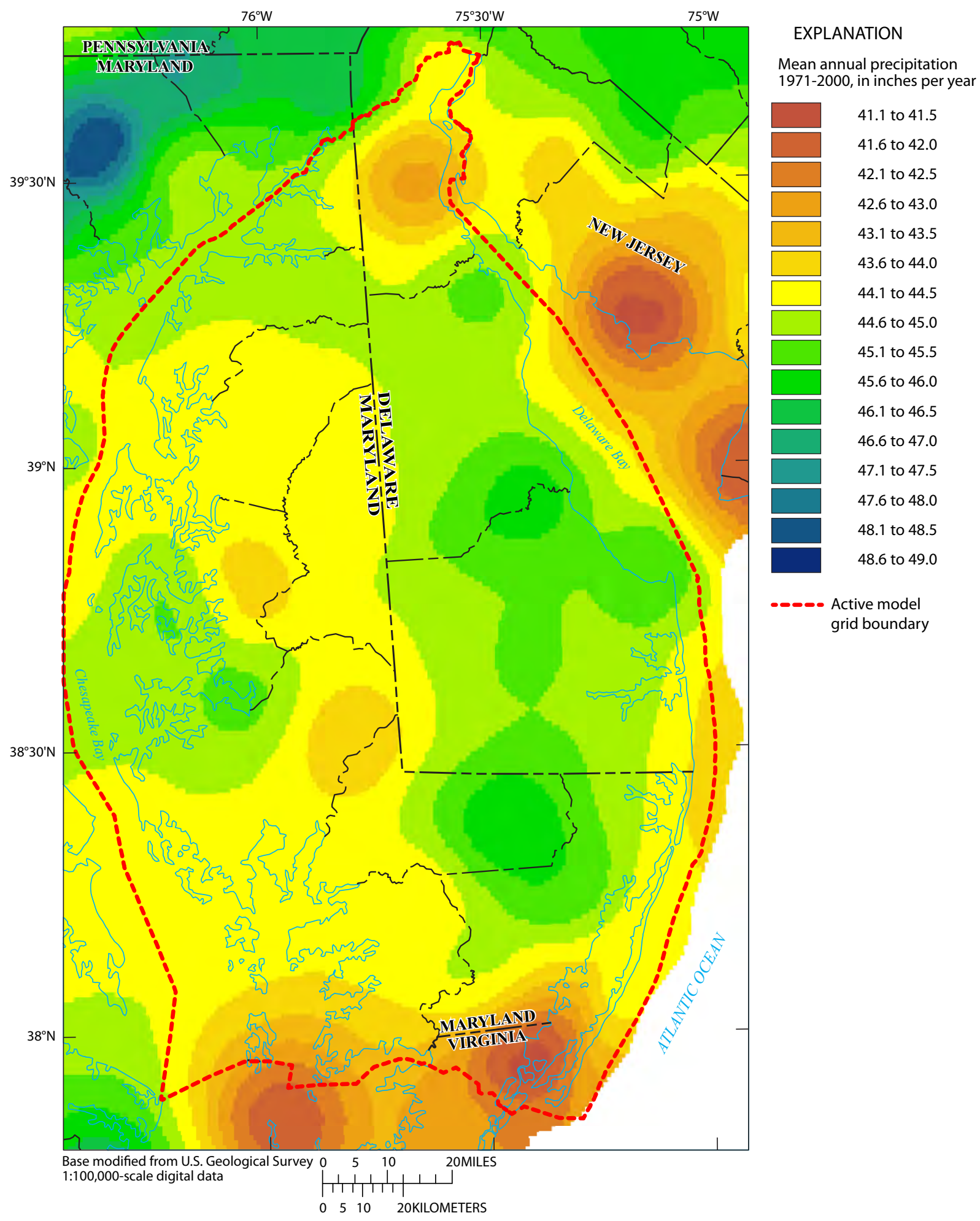

Figure 10. Mean annual precipitation on the Delmarva Peninsula from 1971 to 2000 based on the PRISM climate dataset (Daly and others, 2008). Data retrieved July 2009 from http://www.prism.oregonstate.edu. 


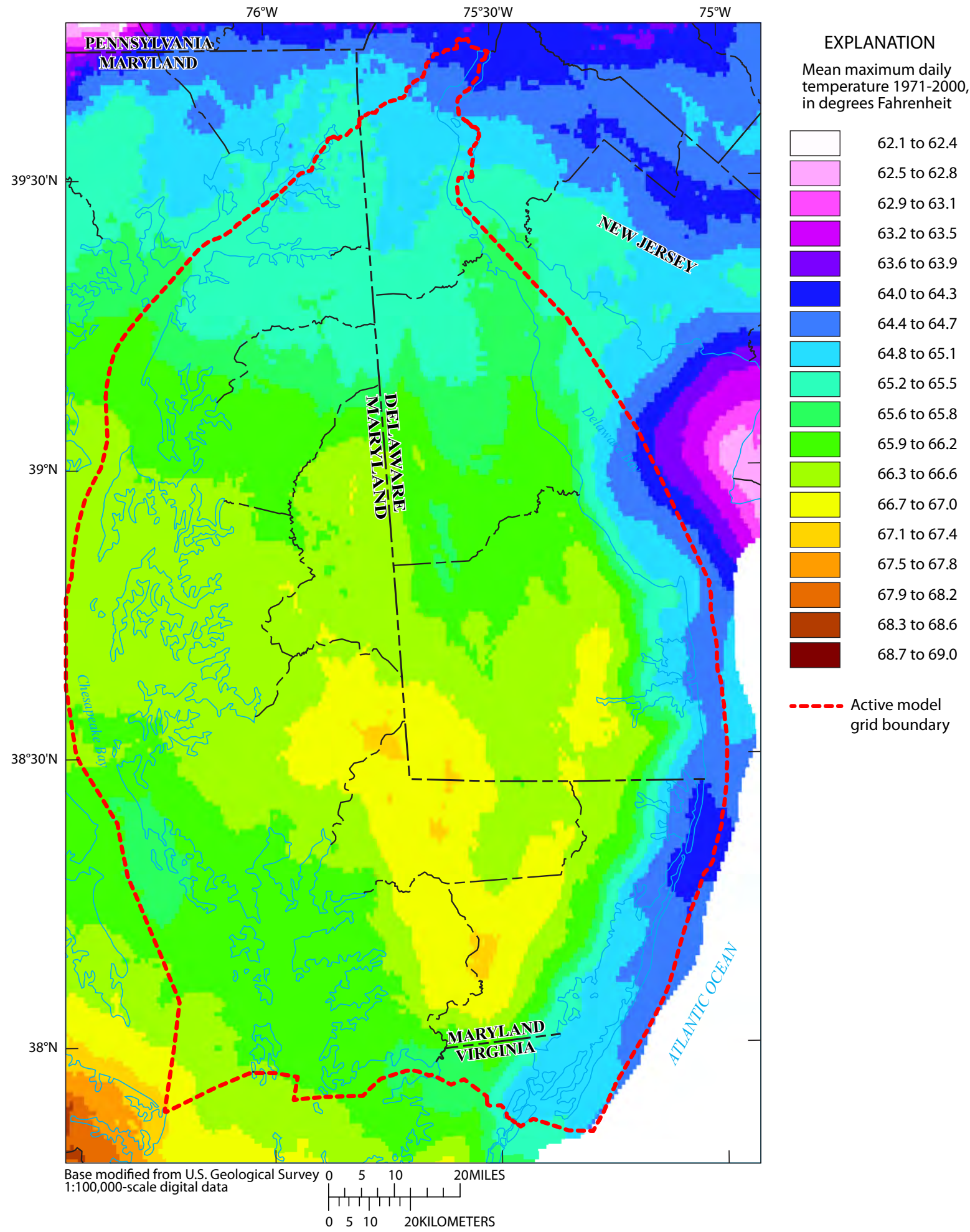

Figure 11. Mean maximum daily temperature on the Delmarva Peninsula from 1971 to 2000 based on the PRISM climate dataset (Daly and others, 2008). Data retrieved July 2009 from http://www.prism.oregonstate.edu. 


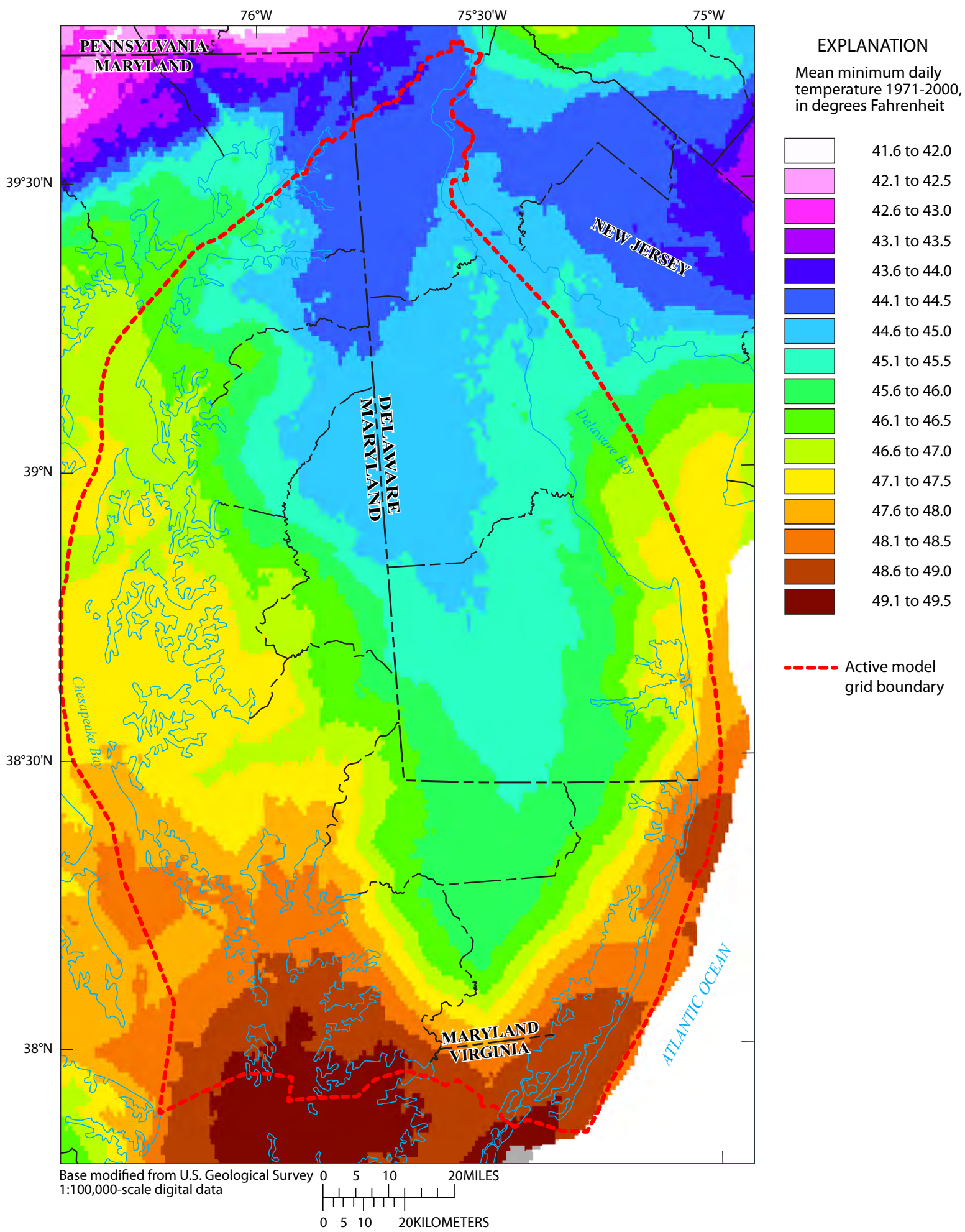

Figure 12. Mean minimum daily temperature on the Delmarva Peninsula from 1971 to 2000 based on the PRISM climate dataset (Daly and others, 2008). Data retrieved July 2009 from http://www.prism.oregonstate.edu. 


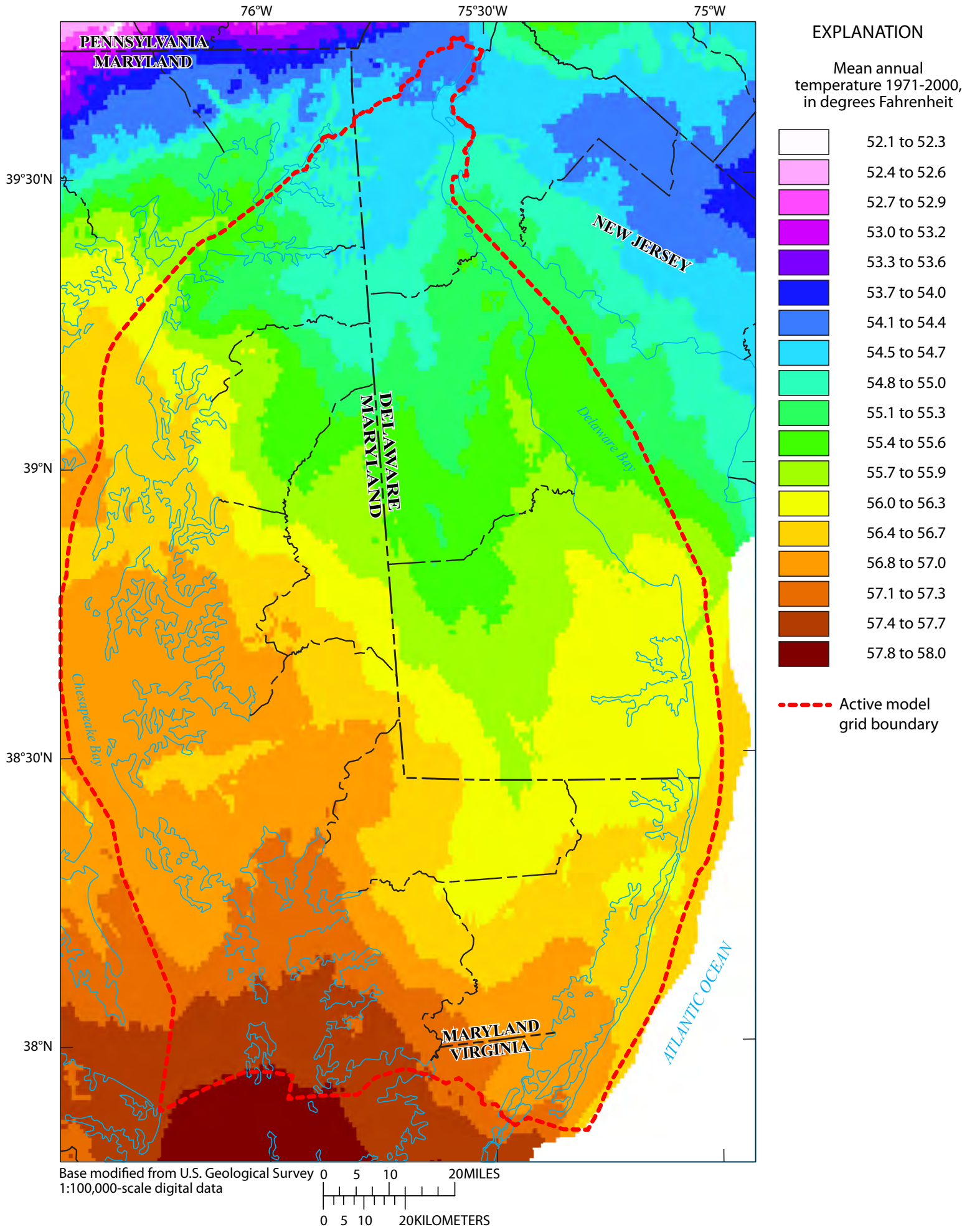

Figure 13. Mean annual temperature on the Delmarva Peninsula from 1971 to 2000 based on the PRISM climate dataset (Daly and others, 2008). Data retrieved July 2009 from http://www.prism.oregonstate.edu. 


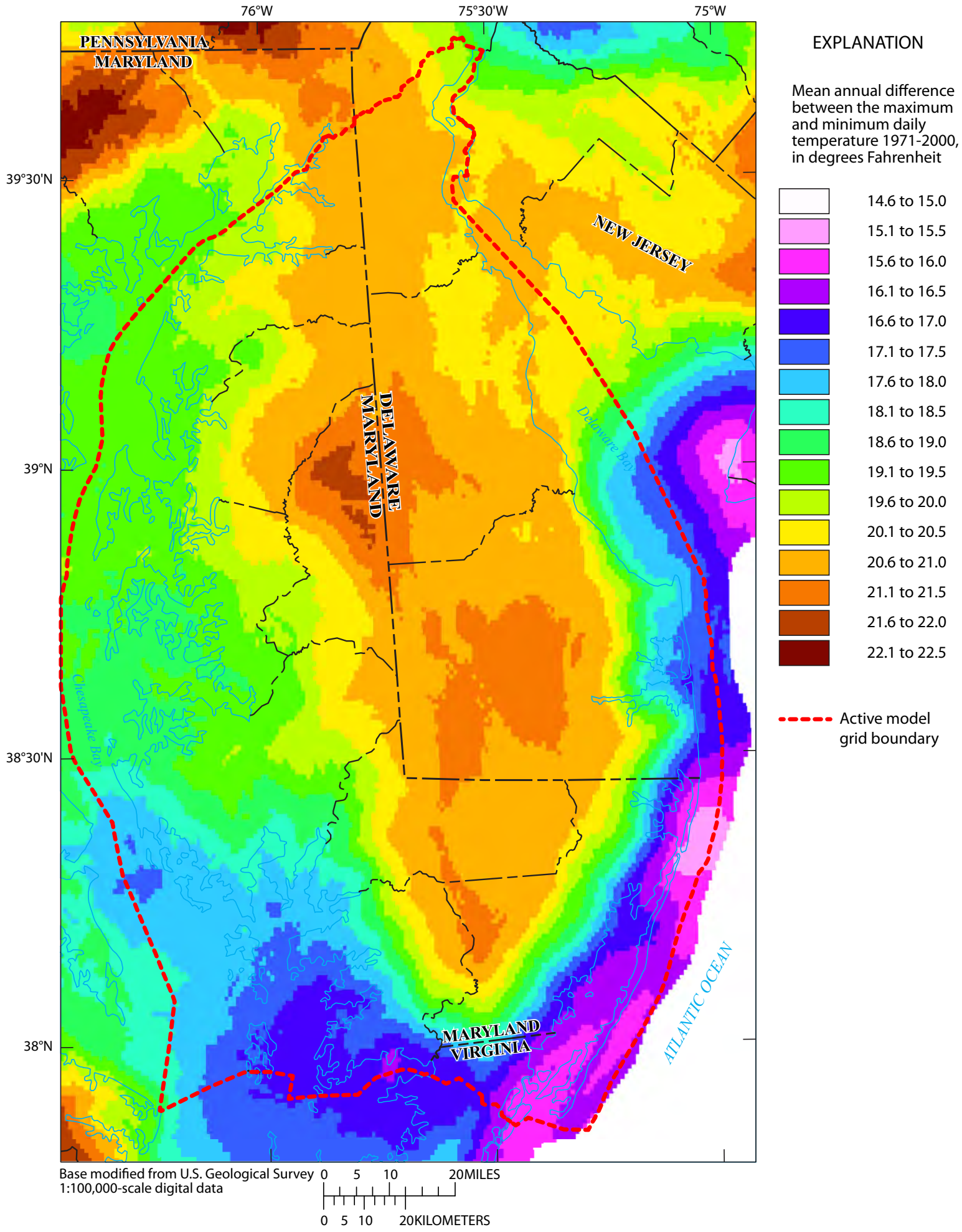

Figure 14. Mean annual difference between the maximum and minimum daily temperature on the Delmarva Peninsula from 1971 to 2000 based on the PRISM climate dataset (Daly and others, 2008). Data retrieved July 2009 from http://www.prism.oregonstate.edu. 
This regression was based on estimates of ET using a waterbalance approach for several dozen watersheds across the entire State of Virginia. The ET rate was also reduced by 1.3 percent for each one percent of the land surface that was impervious, as in the study of Sanford and others (2012). The resulting distribution of ET is relatively uniform across the study area, having a value of about 28 inches per year (in/yr), except within a few miles of the Atlantic coastline where higher humidity results in ET values that are slightly lower, typically 25 to $26 \mathrm{in} / \mathrm{yr}$ (fig. 15). Areas with impervious surface were estimated to have values of $24 \mathrm{in} / \mathrm{yr}$ or less.

Surface runoff is the portion of precipitation that travels over the soil or impervious surface to the nearest stream channel. Surface runoff was estimated for the Coastal Plain environments in the recent study by Sanford and others (2012), which used a regression equation that related surface runoff on the Coastal Plain to soil and sediment character. The regression equation that was used in that study and for comparison in this study is

$$
R_{o}=11.0 F G+7.5 M G+4.1 C G,
$$

where

$$
\begin{array}{cl}
R_{o} & \text { is surface runoff, in inches per year; } \\
F G & \text { is the fraction of the watershed that is } \\
\text { underlain by fine-grained sediment; } \\
M G \quad \begin{array}{c}
\text { is the fraction underlain by medium-grained } \\
\text { sediment; and }
\end{array} \\
\begin{array}{c}
\text { is the fraction underlain by coarse-grained } \\
\text { sediment. }
\end{array}
\end{array}
$$

The Nanticoke River watershed in southern Maryland has surface runoff estimated to be about 4 percent of precipitation, or $1.8 \mathrm{in} / \mathrm{yr}$ (Sanford and others, 2012). This rate was compared to the percentage of clay in the Nanticoke watershed soil (fig. 9). A similar comparison was made to watersheds having greater clay contents, and it was determined that the percentage of clay content in the soil divided by a factor of 2 yielded a reasonable estimate of surface runoff in inches per year. Similar to the calculations by Sanford and others (2012), the surface runoff values were adjusted to account for the percentage of impervious surface. This was accomplished by increasing the runoff by 0.58 percent of the precipitation rate for each one percent of impervious surface. The resulting surface runoff across the peninsula (fig. 16) was estimated to be between 1 and $2 \mathrm{in} / \mathrm{yr}$ for sandy soils in the east-central region, and up to 3 to $4 \mathrm{in} / \mathrm{yr}$ in the western tidal region of Chesapeake Bay. Many locations having a high percentage of impervious surface have estimated surface-runoff values that exceed $5 \mathrm{in} / \mathrm{yr}$.

The total runoff for the peninsula was calculated by subtracting the evapotranspiration from the precipitation (fig. 17). The mean-annual total runoff for the peninsula varied from less than $16 \mathrm{in} / \mathrm{yr}$ in the central region in Maryland to over $18 \mathrm{in} / \mathrm{yr}$ near the Atlantic coast. The recharge to the water table was calculated by subtracting the surface runoff from the total runoff. The mean annual recharge across the peninsula (fig. 18) was estimated to be from 12 to $13 \mathrm{in} / \mathrm{yr}$ in some areas with a high clay content in the western and southwestern regions, to $14 \mathrm{in} / \mathrm{yr}$ in much of the central region, to 15 to $17 \mathrm{in} / \mathrm{yr}$ in eastern areas with sandy soils and along the Atlantic coastline; all of these recharge values (fig. 18) were entered into the MODFLOW model in this study. The values were specified and did not require adjustment during the calibration procedure, as discussed further in the model calibration section herein.

\section{Geologic Characteristics}

The Delmarva Peninsula is underlain by Coastal Plain sediments that are Cretaceous through Quaternary in age and alternate between fluvial and marine sands, silts, and clays (Andreasen and others, 2007). The sediments overlie Paleozoic and Precambrian crystalline bedrock, and dip and thicken to the southeast (fig. 19). Within the study area, the Cretaceous-age sediments crop out above sea level along the western side of northernmost Chesapeake Bay toward the northeast into northernmost Delaware. The bottom surface of the Cretaceous-age sediments dips to the southeast and is more than 6,000 ft below sea level along the Atlantic coast of Maryland and Delaware. Cretaceous- and Tertiary-age sedimentary layers thicken toward the southeast accordingly, pinching out at various locations beneath the peninsula (figs. 20 and 21). These sediments are overlain by Quaternary deposits that are fluvial, marine, and eolian in origin (Owens and Denny, 1979). The bottom surface of the Quaternary deposits varies in elevation from over $60 \mathrm{ft}$ above NGVD 29 in the northern peninsula to more than $100 \mathrm{ft}$ below NGVD 29 near the east-west border between Maryland and southern Delaware (fig. 22).

Because the model layers are constant in thickness areally, each represents the geologic framework by uniquely representing the corresponding stratigraphic unit in space based on how the grid layer intersects the strata at each cell location. This hydrogeologic representation in the model was constructed by intersecting the model layers with the digital stratigraphic-unit surfaces created in a hydrogeologic framework by Andreasen and others (2007). Layer 1, being the shallowest layer and $10 \mathrm{ft}$ thick, mostly represents the Quaternary deposits, except where they have been breached in the northern region by stream erosion that has exposed the underlying Tertiary and Cretaceous units (fig. 23). Layer 2 is $20 \mathrm{ft}$ thick and also dominated by Quaternary deposits, but it has a larger region of Tertiary and Cretaceous units represented in the western and northern peninsula compared to layer 1 (fig. 24). Layer 3 is $30 \mathrm{ft}$ thick and composed of the Quaternary units, mostly in the central and southeastern peninsula, with only a few scattered areas of Quaternary deposits present in the northern and northwestern peninsula (fig. 25). The remainder of layer 3 is composed of the Tertiary and Cretaceous units that underlie the Quaternary units. Layer 4 is $40 \mathrm{ft}$ thick and composed of Tertiary and Cretaceous units, except for the southeastern quadrant of the peninsula and few isolated cells in the northwestern part (fig. 26). Layer 5 is $50 \mathrm{ft}$ thick and 


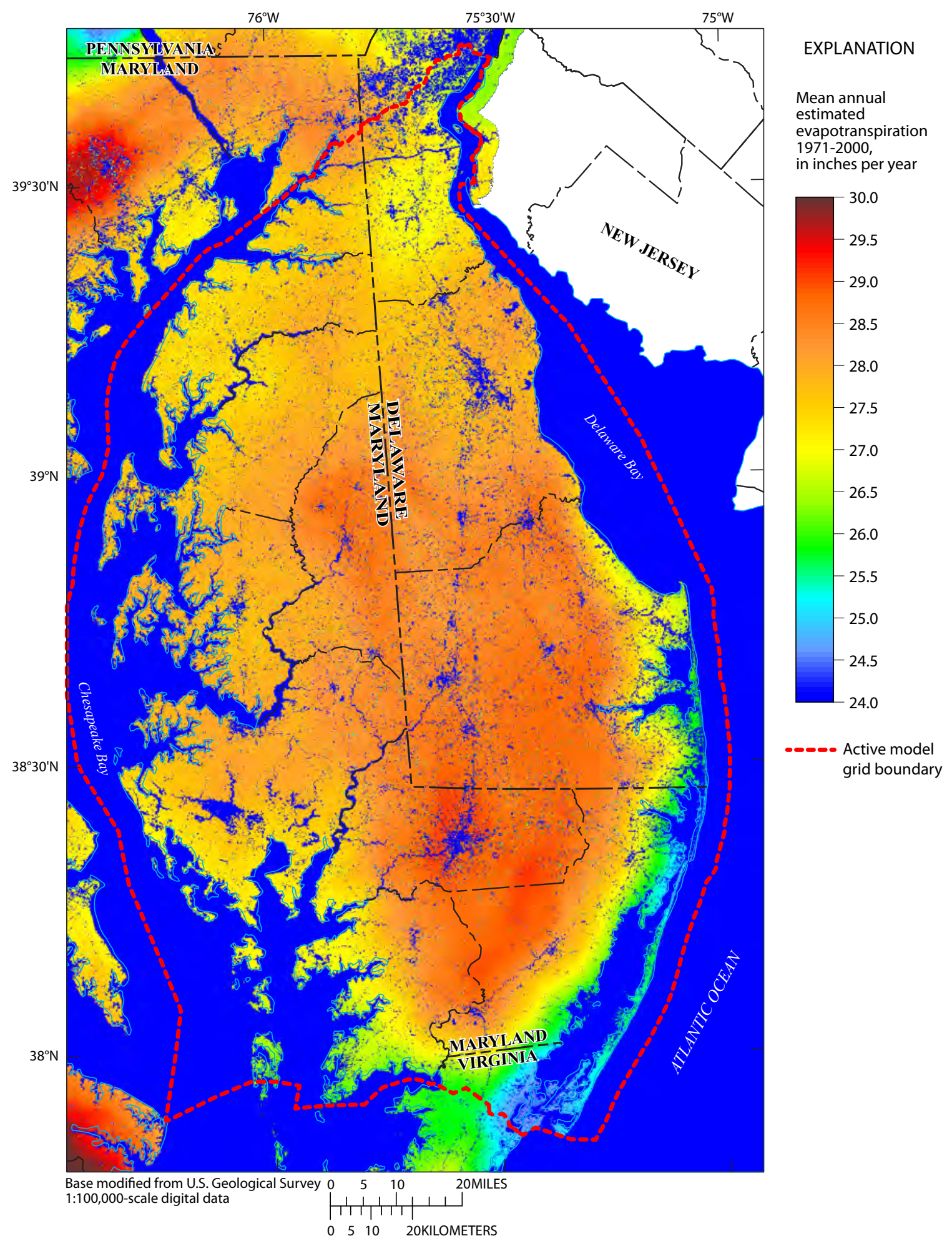

Figure 15. Mean annual estimated evapotranspiration on the Delmarva Peninsula from 1971 to 2000 based on the climate regression equation of Sanford and others (2012). 


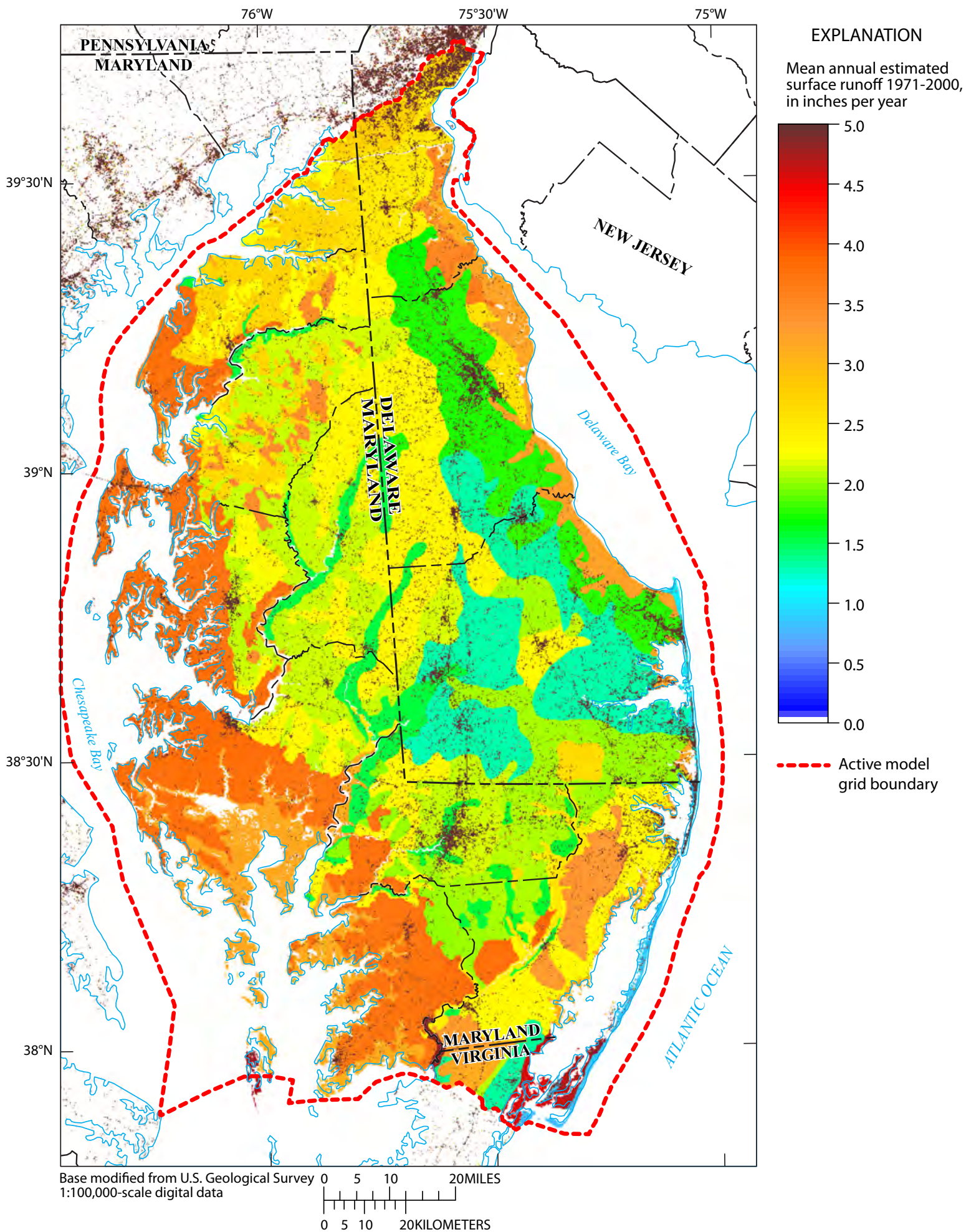

Figure 16. Mean-annual estimated surface runoff on the Delmarva Peninsula from 1971 to 2000 based on the regression equations of Sanford and others (2012) for the Coastal Plain physiographic province and the clay content of the soils. Regions outside the active model area only show runoff for impervious surfaces. 


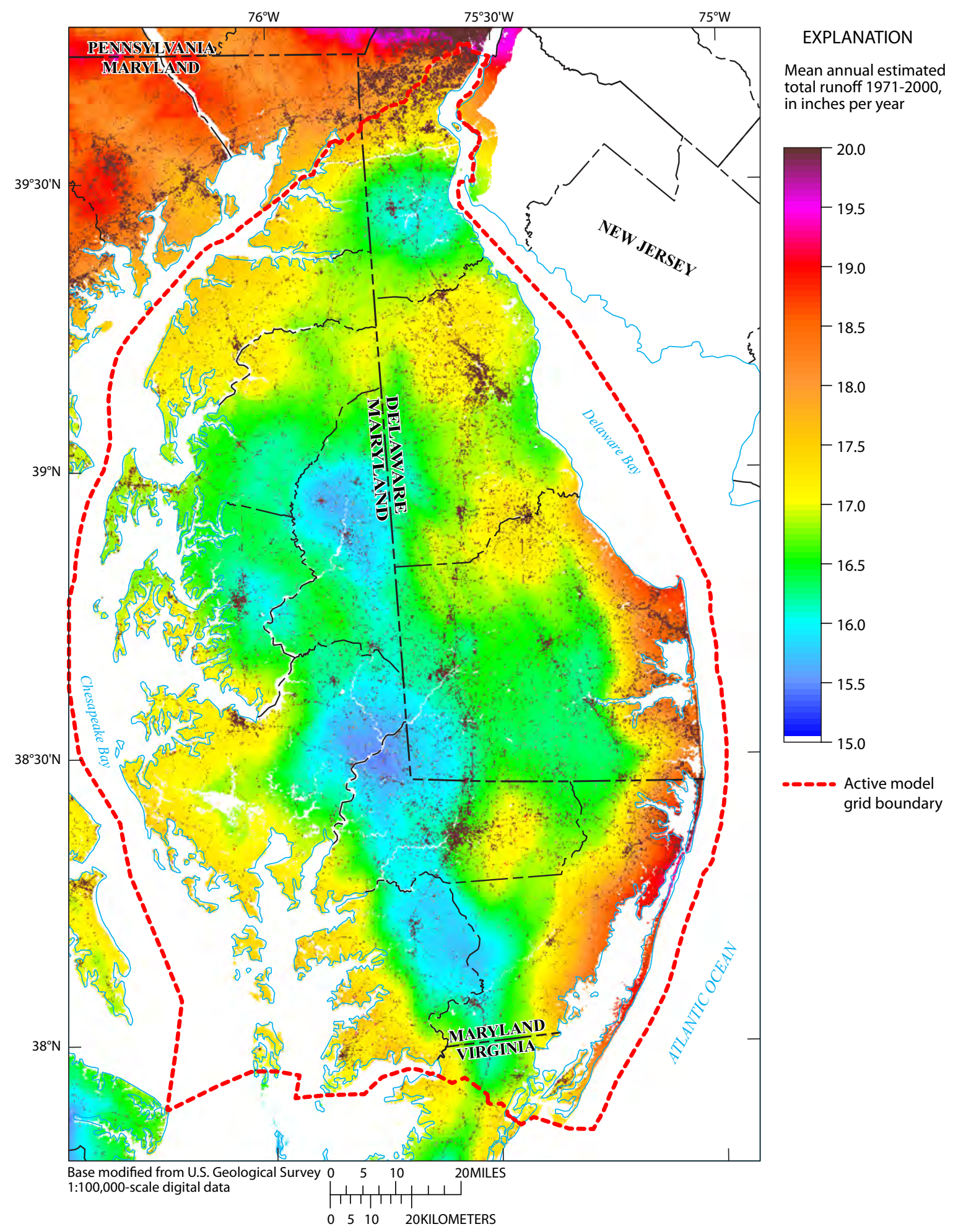

Figure 17. Mean annual estimated total runoff on the Delmarva Peninsula from 1971 to 2000 calculated by subtracting evapotranspiration (fig. 14) from precipitation (fig. 9). 


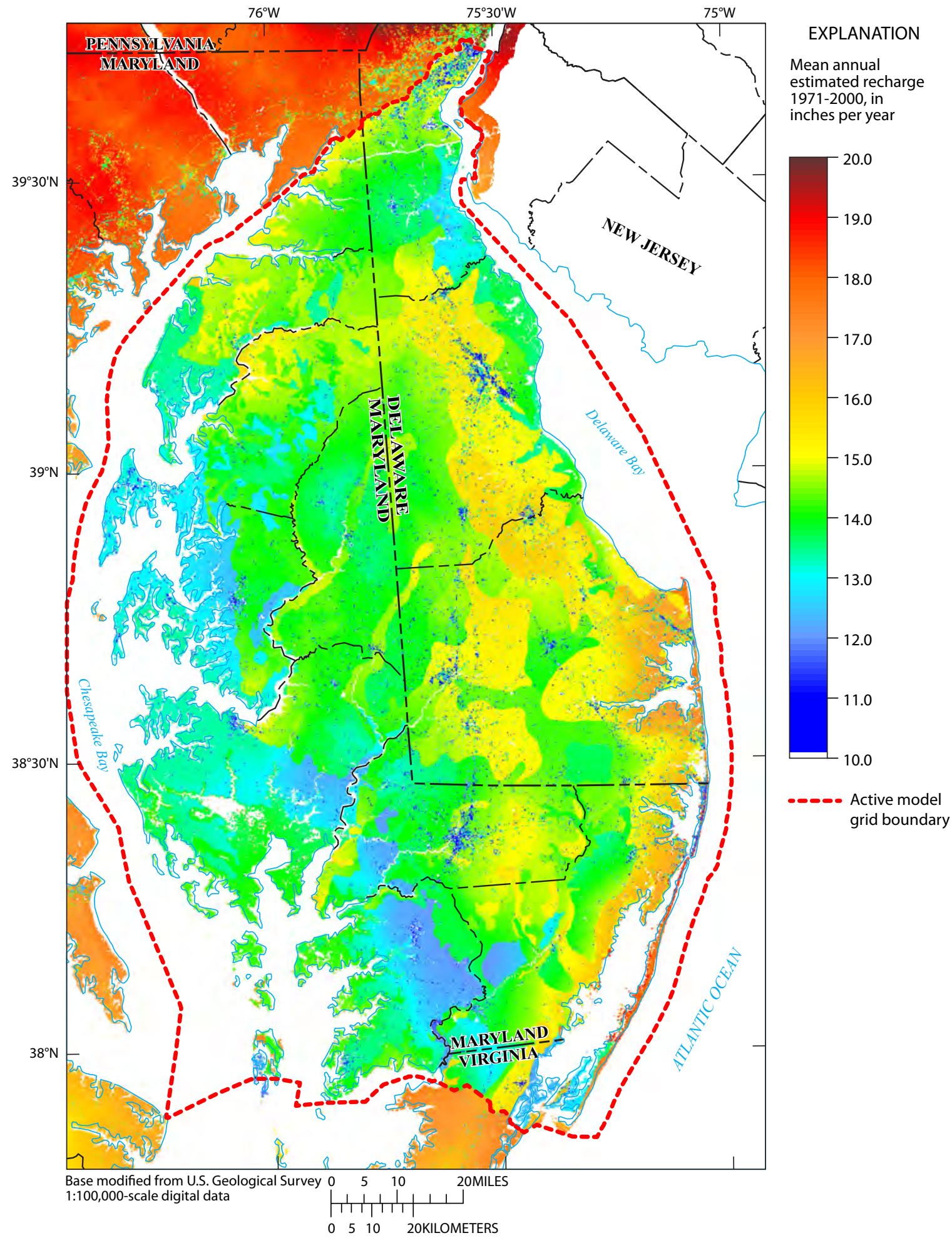

Figure 18. Mean annual estimated recharge on the Delmarva Peninsula from 1971 to 2000 based on the precipitation from the PRISM climate database and the climate and runoff regression equations of Sanford and others (2012). Values outside the active model area (fig. 3) represent total runoff rather than recharge. 


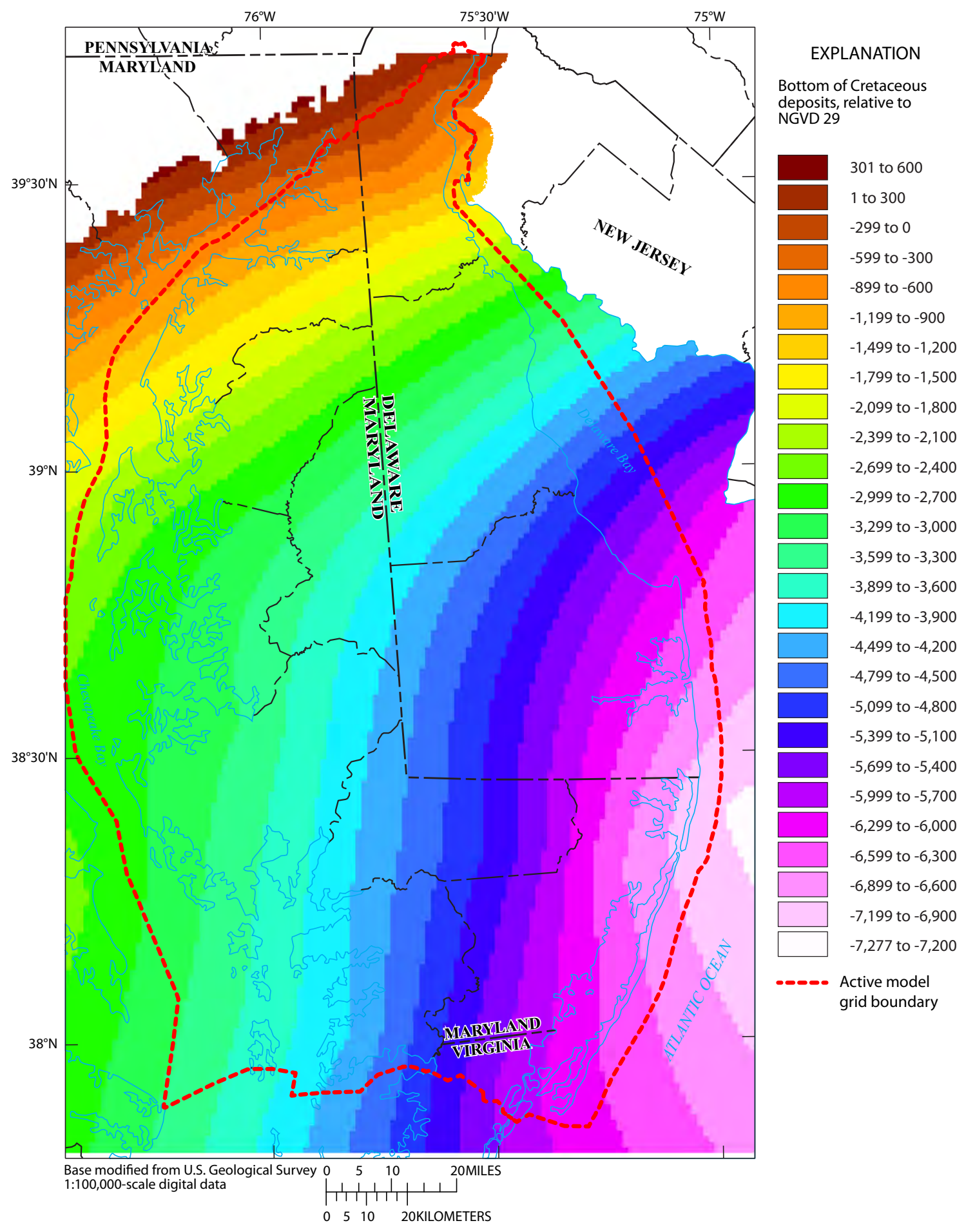

Figure 19. Bottom surface of the Cretaceous deposits on the Delmarva Peninsula relative to sea-level datum NGVD 29. Data surface from Andreasen and others (2007). 


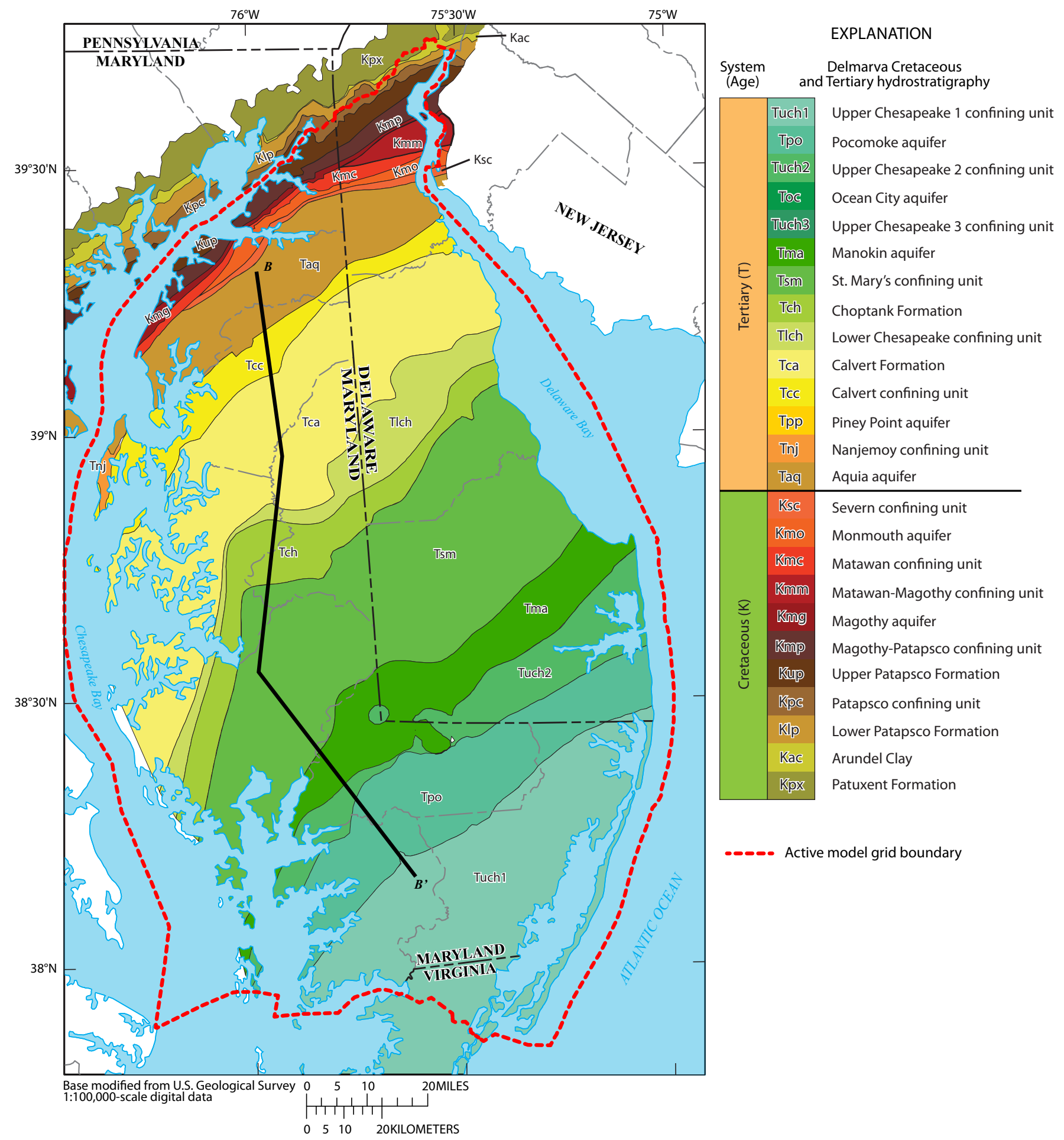

Figure 20. Locations where various Cretaceous $(\mathrm{K})$ and Tertiary $(\mathrm{T})$ deposits outcrop at the land surface or subcrop beneath Quaternary deposits on the Delmarva Peninsula. Section along line $B-B^{\prime}$ is shown in figure 21. Data files from Andreasen and others (2007). 
composed almost entirely of Tertiary and Cretaceous units except for a few isolated patches of Quaternary units (fig. 27). Layers 6 and 7 are 60 and $90 \mathrm{ft}$ thick, respectively, and composed entirely of Tertiary and Cretaceous units (figs. 28 and 29 ), except for one isolated cell in layer 6 . In all of the layers, the Cretaceous units are represented only in the far northern and northeastern peninsula, because the remainder of the Cretaceous units dipping to the southeast exceed the $300-\mathrm{ft}$ depth represented in the model. Various units also extend beneath the Chesapeake and Delaware Bays and the Atlantic Ocean within the active model area (not shown in figs. 23 to 29). Hydraulic conductivity values were assigned to each of the units, as described in the next section.

\section{Model Calibration}

The groundwater model was calibrated using water levels and tracer-based ages determined from a number of observation wells across the peninsula. The water-level observations used to calibrate the model were selected from existing USGS wells and had to represent good spatial coverage and consist of at least 12 measurements made over several seasons (to eliminate seasonal variation) per well. The observations also had to represent natural conditions and not have been under the influence of pumping. The number of candidate wells was reduced to 48 using these criteria (table 1) and ranged in depth from 10 to $85 \mathrm{ft}$ below land surface. The wells were chosen to be distributed as evenly as possible across the peninsula in order to represent different regions and formations during the calibration procedure (fig. 30). In Queen Anne's County (fig. 2), the two northernmost wells (fig. 30) are located very close to the same site.

Base flows to streams are frequently used to calibrate models that represent humid regions, such as the Delmarva Peninsula, in order to constrain water fluxes to a degree that cannot be accomplished using water levels alone (Hill and Tiedeman, 2007). Base flow is considered here to be that portion of the total streamflow that originates as groundwater

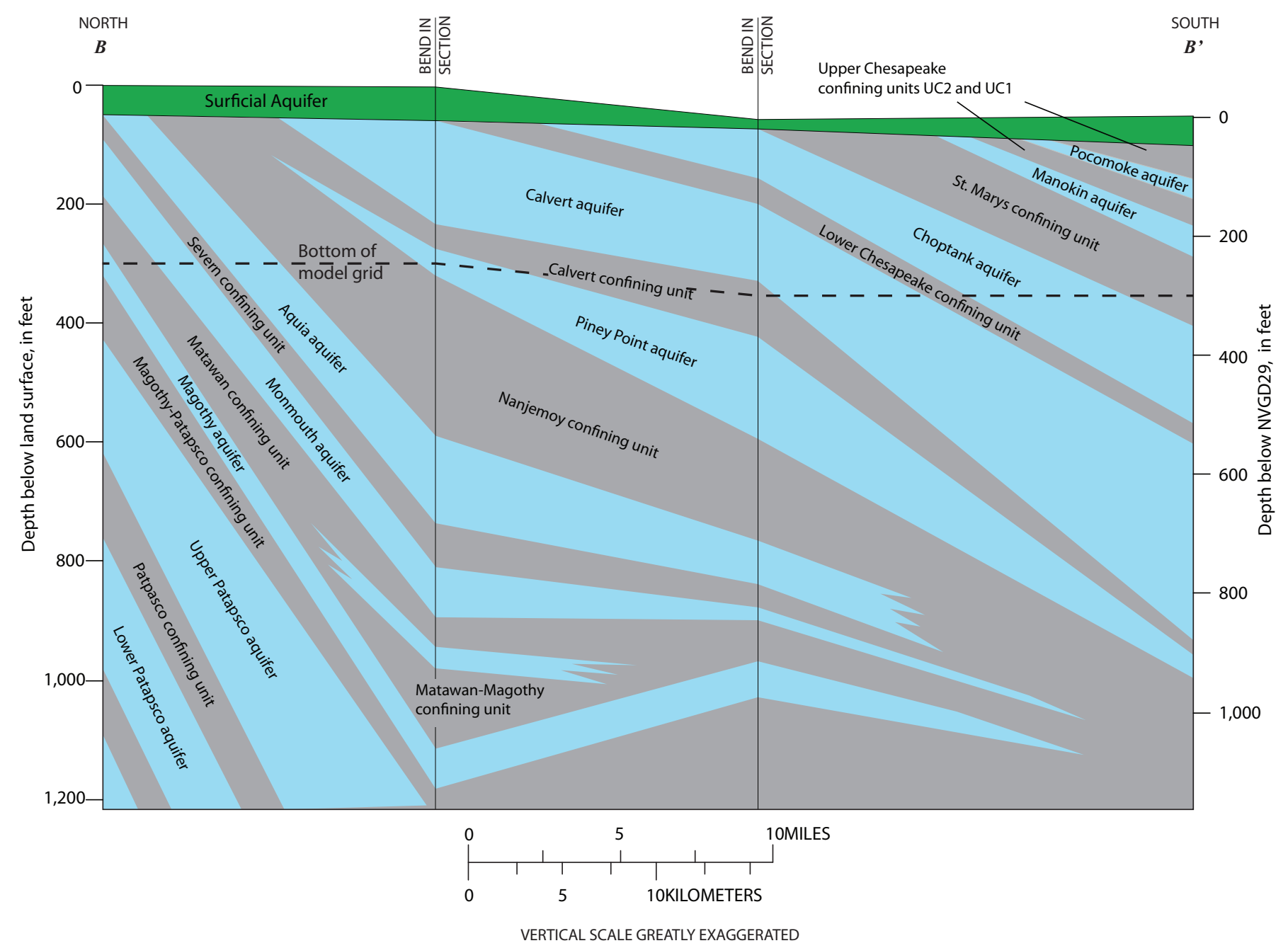

Figure 21. Cross-sectional view showing dipping of confined hydrogeologic units beneath the surficial aquifer along the line $B$ - $B^{\prime}$. See figure 20 for location of section line. Modified from Andreasen and others (2007). 


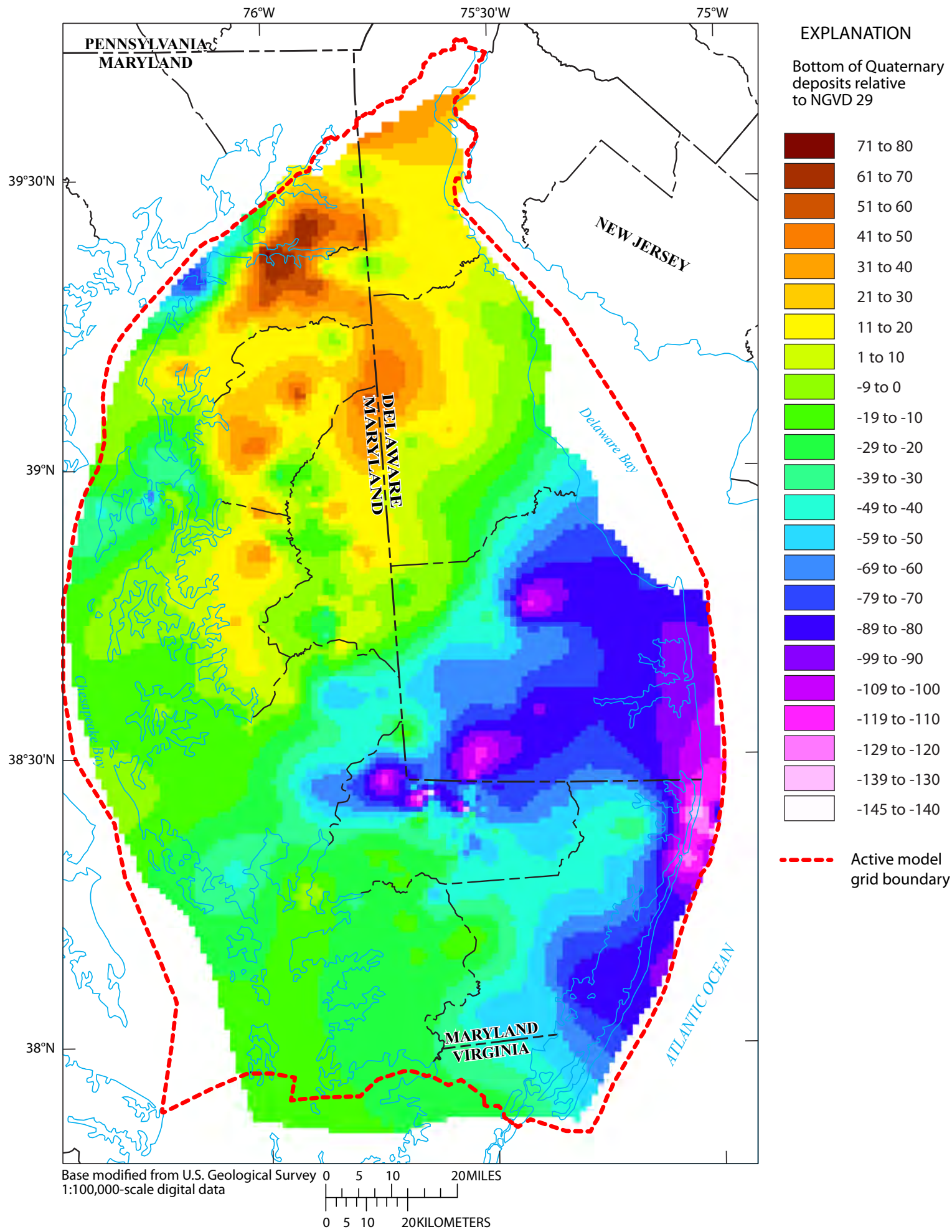

Figure 22. Bottom surface of the Quaternary deposits on the Delmarva Peninsula relative to sea-level datum NGVD 29. Data surface from Andreasen and others (2007). 


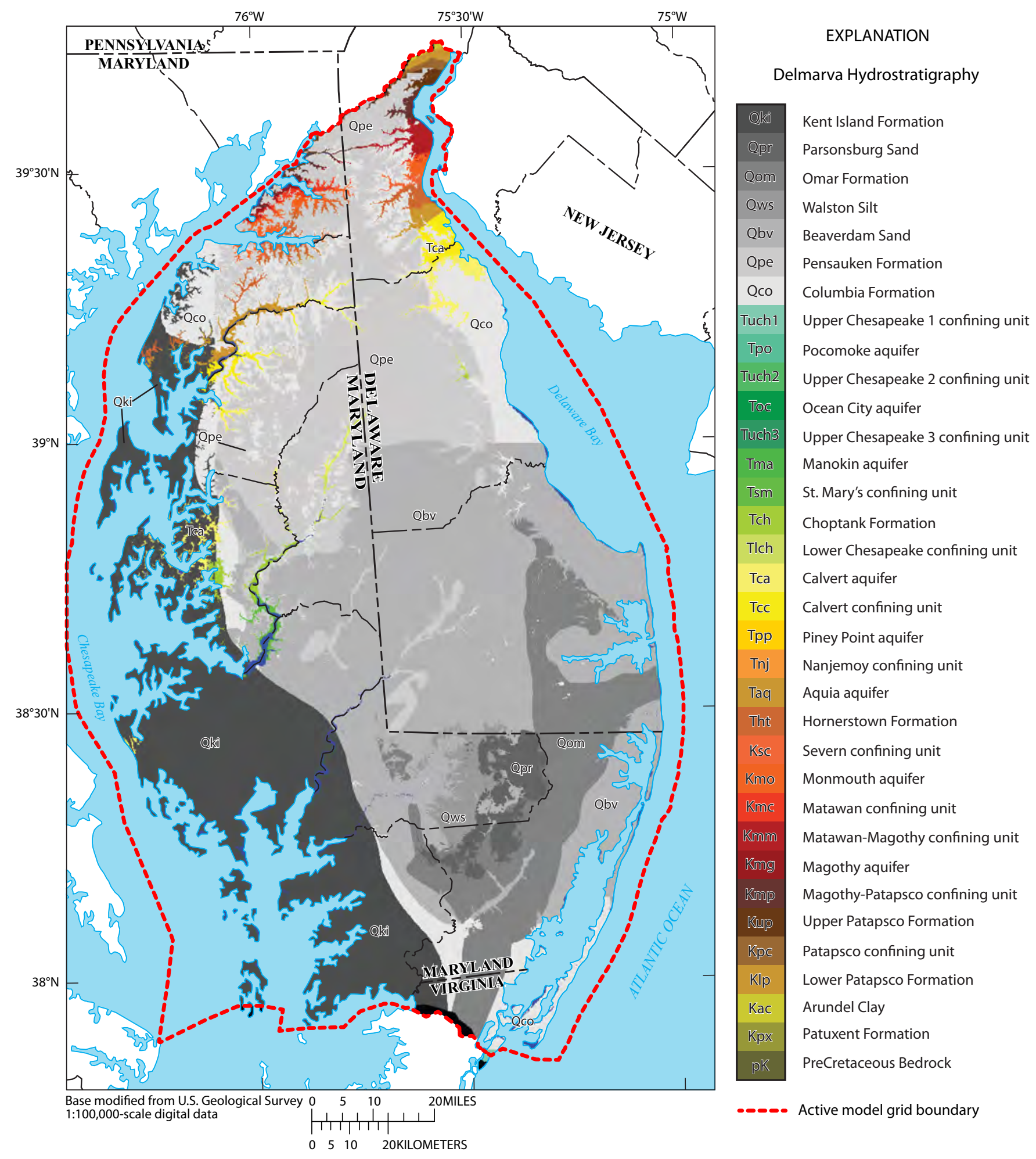

Figure 23. Distribution of geologic units within layer 1 of the model grid. The top of layer 1 is the land surface and the bottom is 10 feet below land surface. Formations also extend under the water bodies in the active model area (fig. 3). 


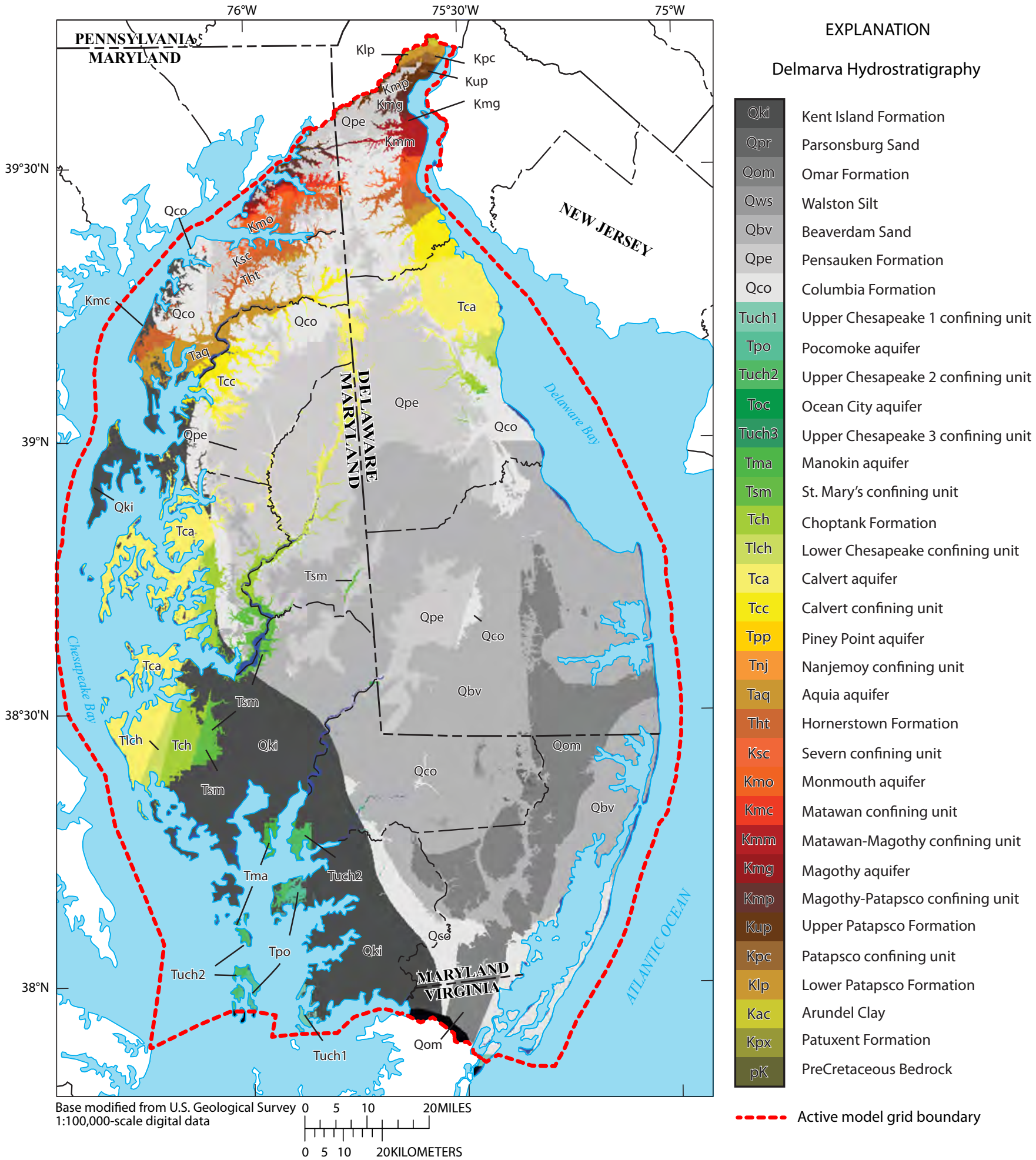

Figure 24. Distribution of geologic units within layer 2 of the model grid. The top and bottom of layer 2 are 10 and $30 \mathrm{ft}$ below land surface. Formations also extend underneath the water bodies within the active model area (fig. 3). 


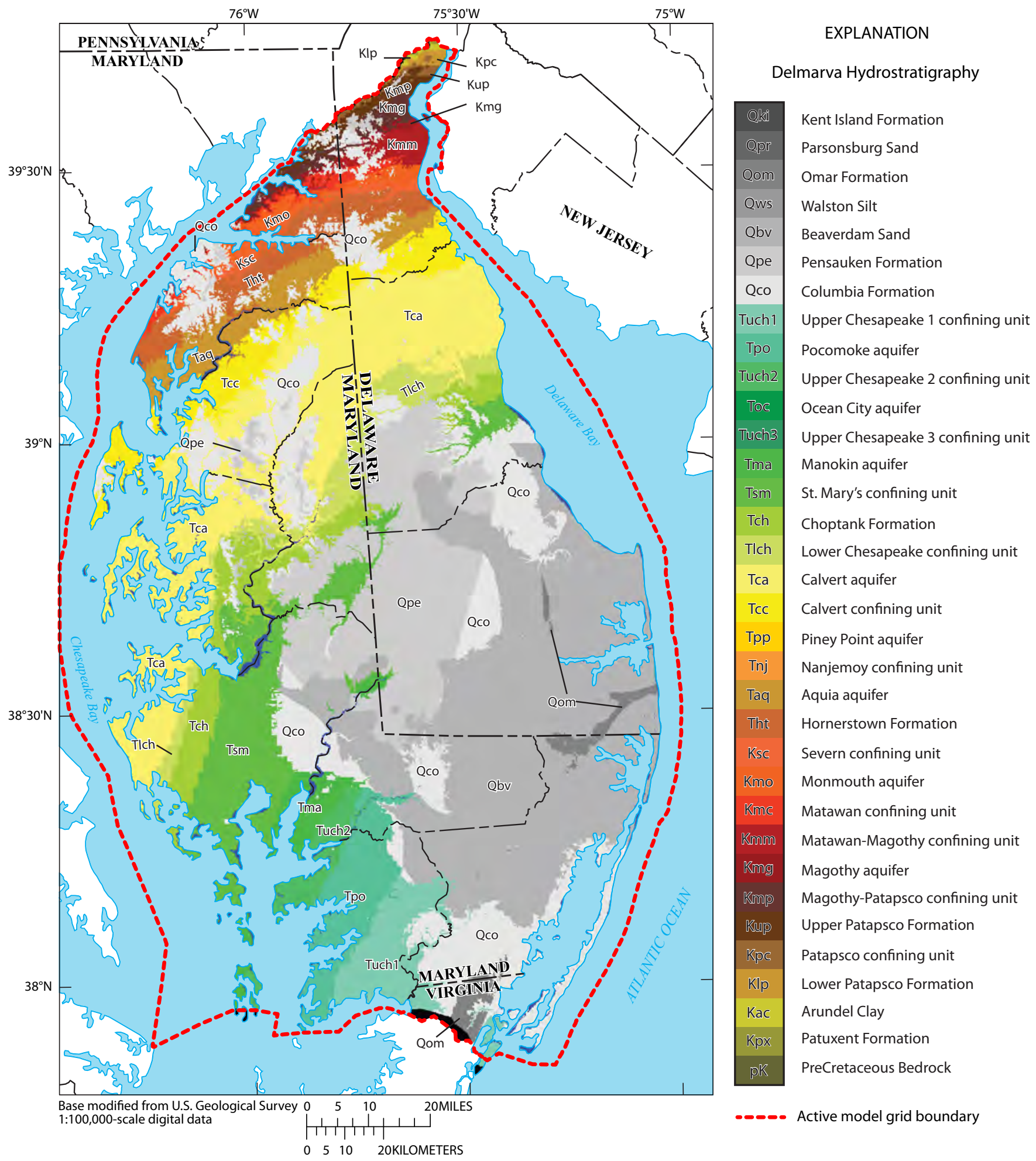

Figure 25. Distribution of geologic units within layer 3 of the model grid. The top and bottom of layer 3 are 30 and 60 feet below land surface. Formations also extend underneath the water bodies within the active model area (fig. 3). 


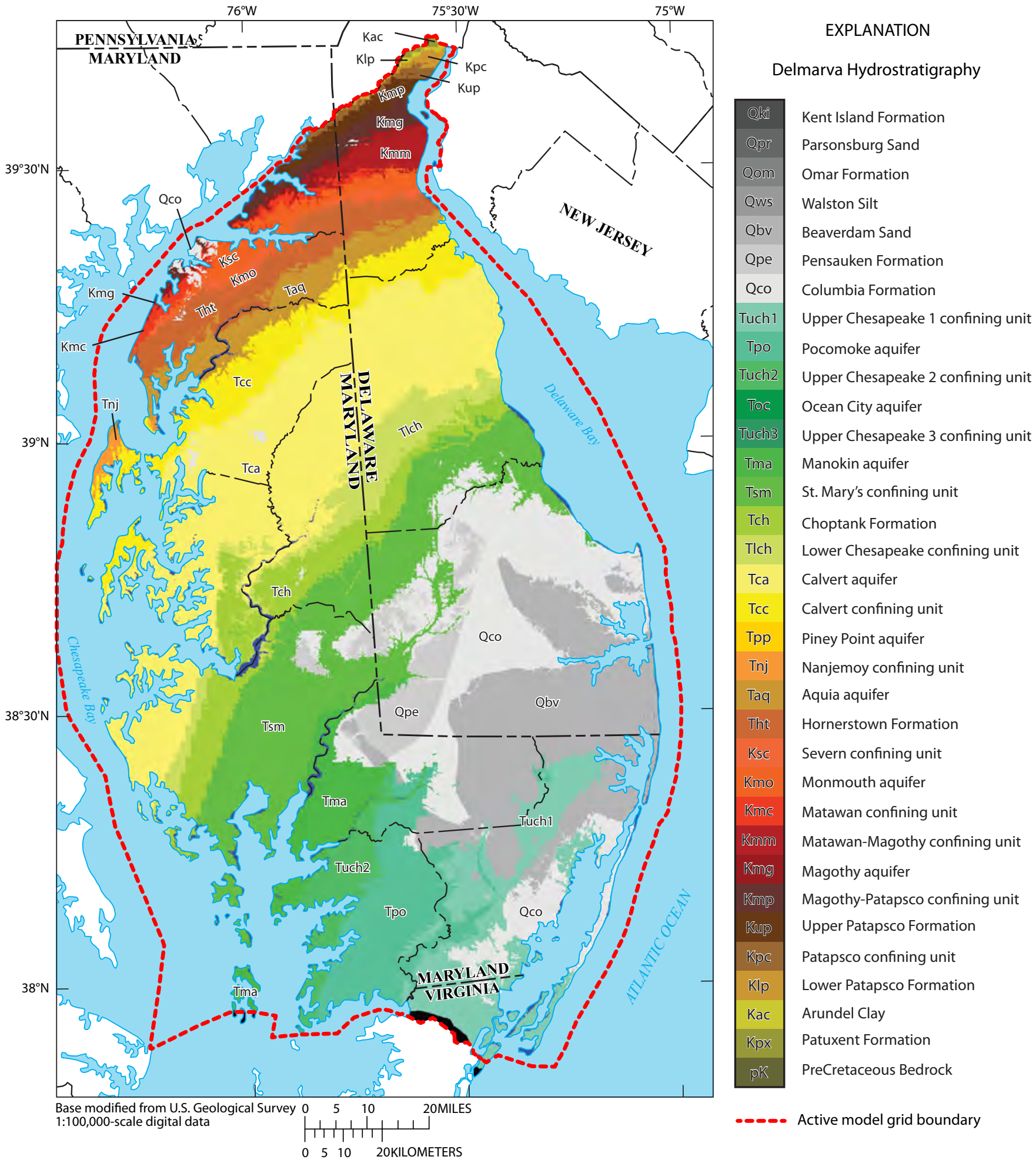

Figure 26. Distribution of geologic units within layer 4 of the model grid. The top and bottom of layer 4 are 60 and 100 feet below land surface. Formations also extend underneath the water bodies within the active model area (fig. 3). 


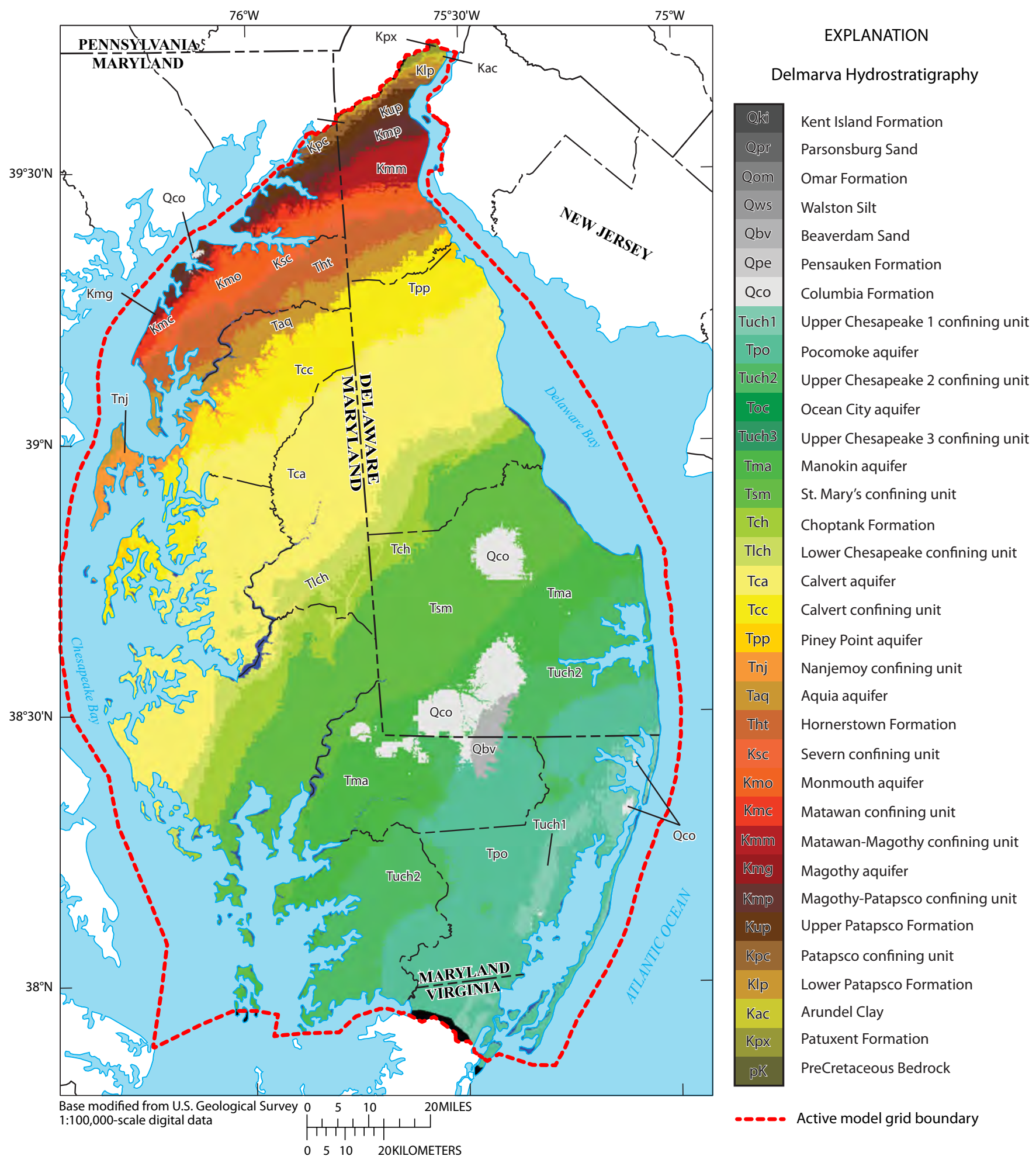

Figure 27. Distribution of geologic units within layer 5 of the model grid. The top and bottom of layer 5 are 100 and 150 feet below land surface. Formations also extend underneath the water bodies within the active model area (fig. 3). 


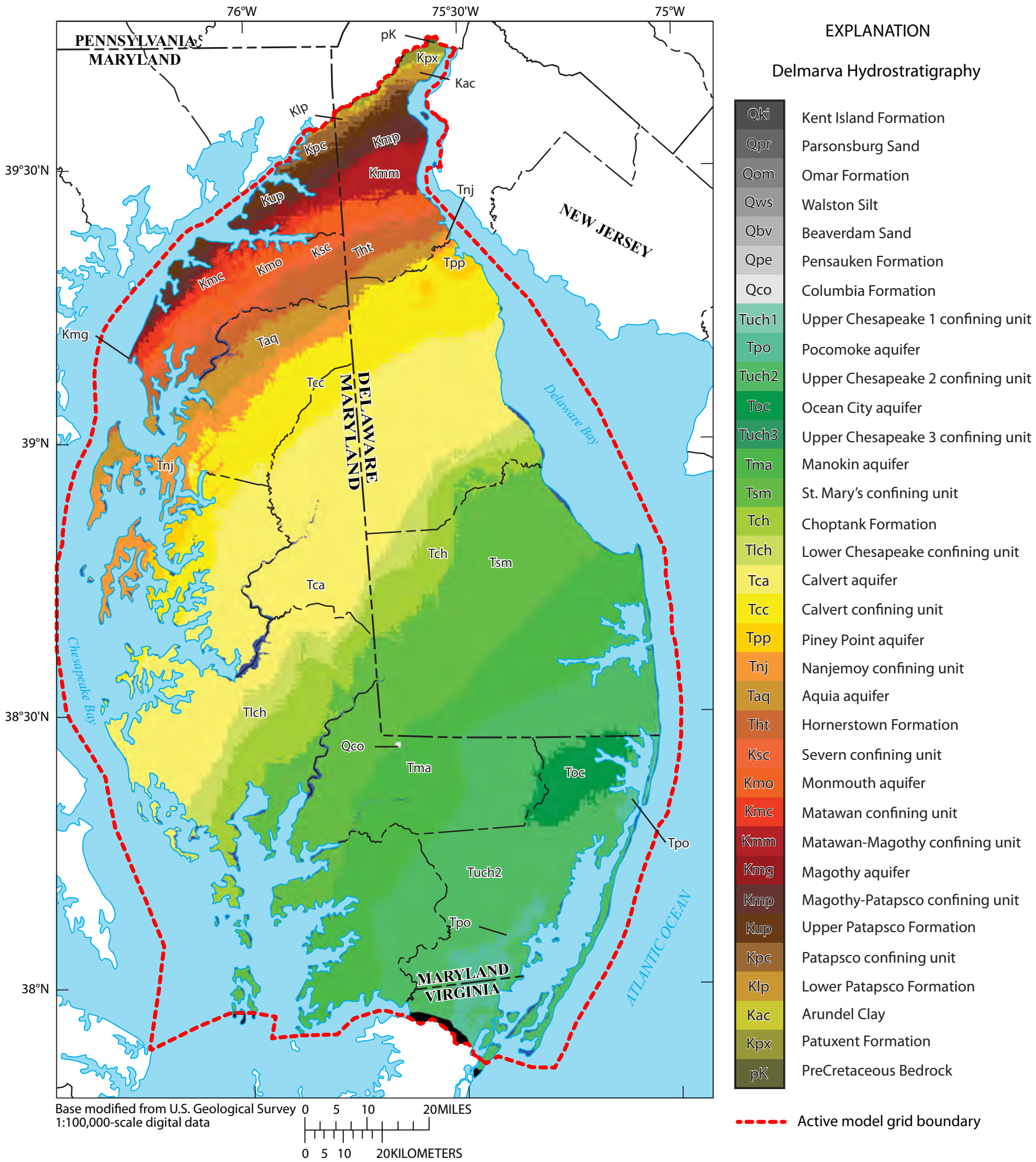

Figure 28. Distribution of geologic units within layer 6 of the model grid. The top and bottom of layer 6 are 150 and 210 feet below land surface. Formations also extend underneath the water bodies within the active model area (fig. 3). 


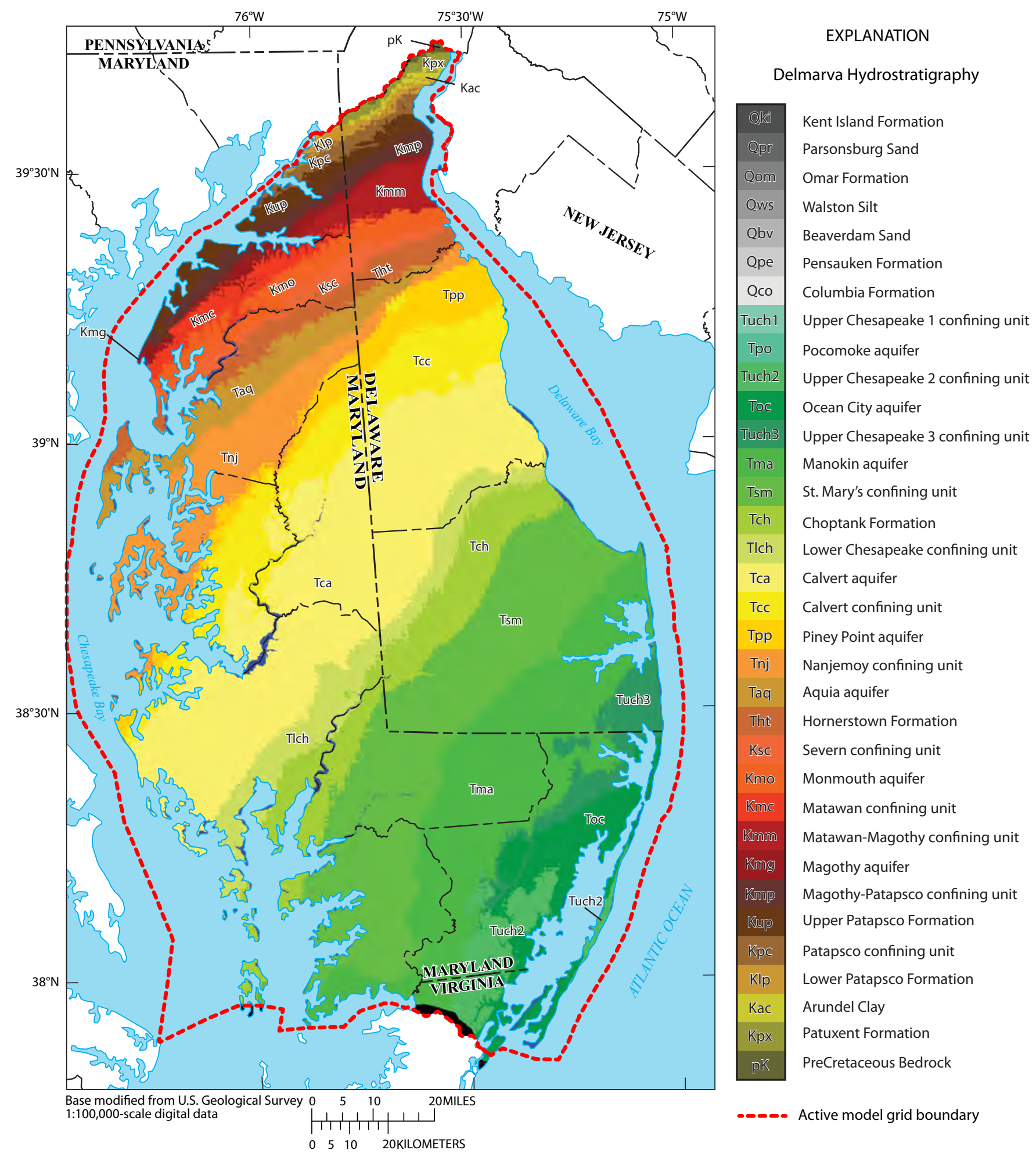

Figure 29. Distribution of geologic units within layer 7 of the model grid. The top and bottom of layer 7 are 210 and 300 feet below land surface. Formations also extend underneath the water bodies within the active model area (fig. 3). 


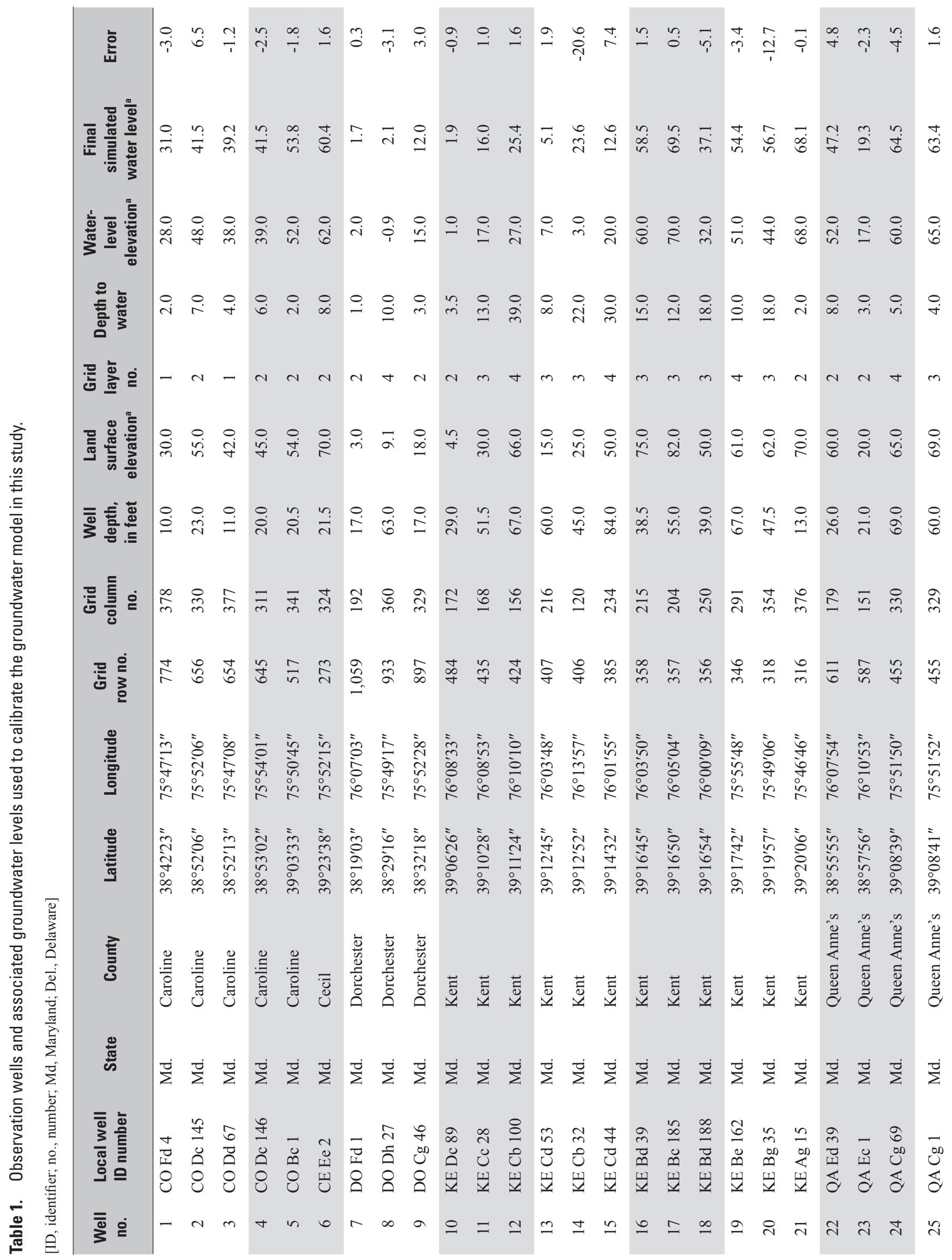




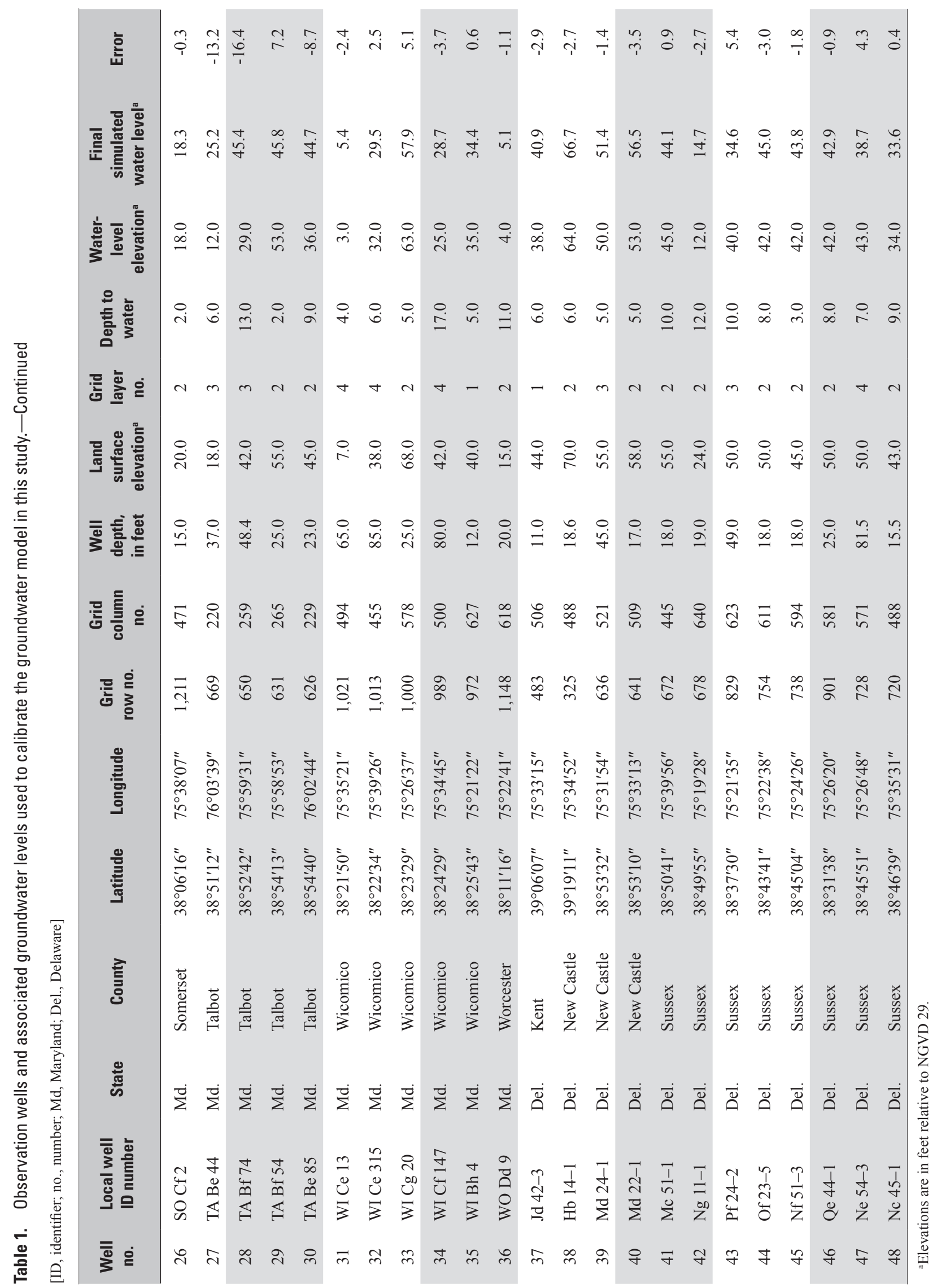




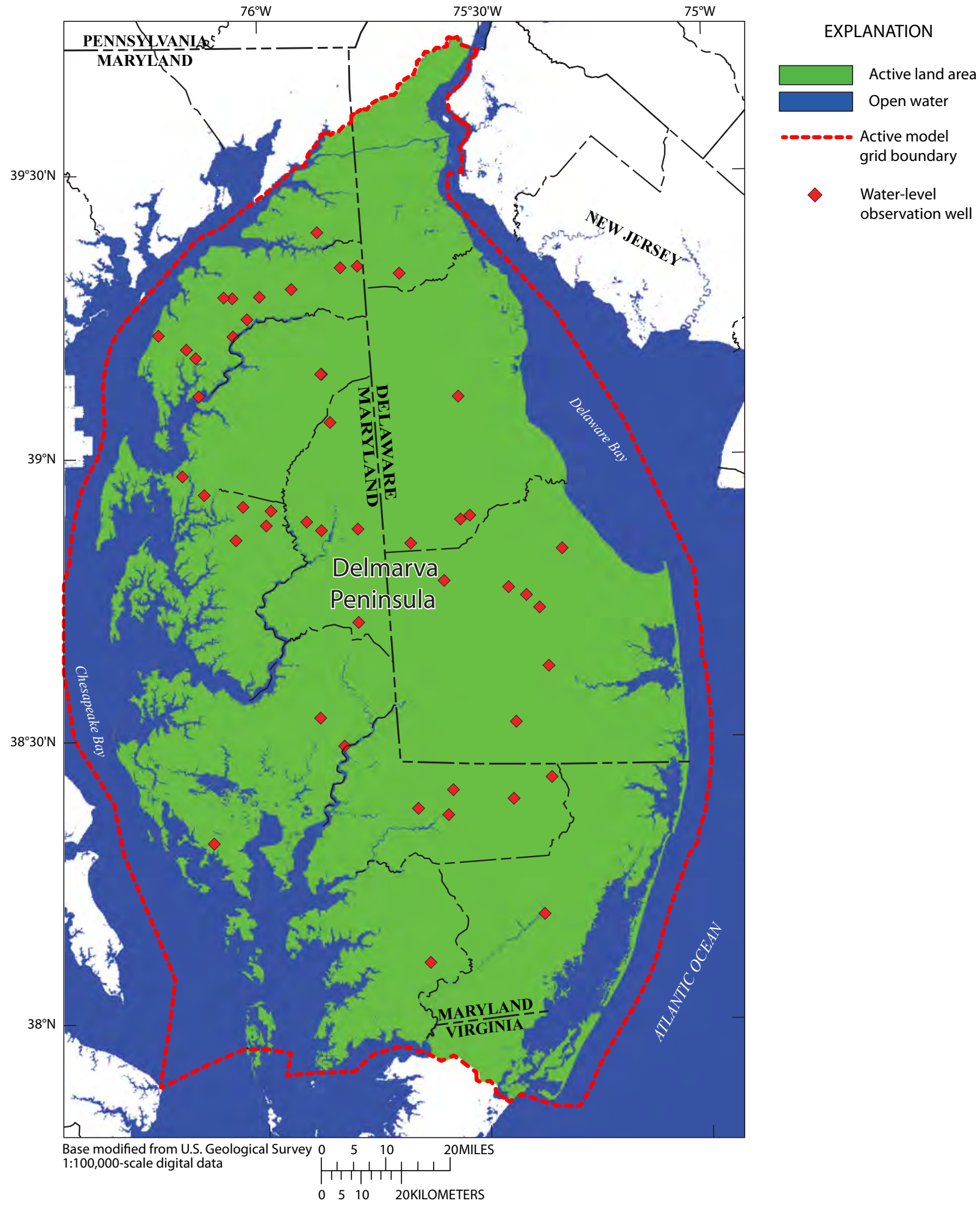

Figure 30. Locations of the 48 wells used for water-level observations. 
Table 2. Watersheds used to compare observed and simulated total runoff from the land surface.

$\left[\mathrm{ft}^{3} / \mathrm{s}\right.$, cubic foot per second]

\begin{tabular}{|c|c|c|c|c|c|c|c|c|}
\hline $\begin{array}{l}\text { Watershed } \\
\text { no. }\end{array}$ & Watershed name & $\begin{array}{l}\text { USGS } \\
\text { station } \\
\text { number }\end{array}$ & Drainage outlet & $\begin{array}{c}\text { Area, } \\
\text { in square } \\
\text { miles }\end{array}$ & $\begin{array}{c}\text { Mean flow } \\
1971-2000 \text {, } \\
\text { in } \mathrm{ft}^{3} / \mathrm{s}\end{array}$ & $\begin{array}{l}\text { Observed } \\
\text { total runoff, } \\
\text { in inches }\end{array}$ & $\begin{array}{l}\text { Simulated } \\
\text { total runoff, } \\
\text { in inches }\end{array}$ & $\begin{array}{c}\text { Error, } \\
\text { in percent }\end{array}$ \\
\hline 1 & Morgan Creek & 01493500 & Chesapeake Bay & 12.7 & 12.4 & 13.3 & 17.1 & 25.3 \\
\hline 2 & Unicorn Branch & 01493000 & Chesapeake Bay & 19.7 & 27.5 & 19.0 & 16.8 & 12.1 \\
\hline 3 & St. Jones River & 01483700 & Delaware Bay & 31.9 & 40.1 & 17.1 & 17.1 & 0.1 \\
\hline 4 & Choptank River & 01491000 & Chesapeake Bay & 113.0 & 143.7 & 17.3 & 16.5 & 4.6 \\
\hline 6 & Nanticoke River & 01487000 & Chesapeake Bay & 75.4 & 92.7 & 16.7 & 16.8 & 0.6 \\
\hline 7 & Pocomoke River & 01485000 & Chesapeake Bay & 60.5 & 77.6 & 17.4 & 16.9 & 3.0 \\
\hline 8 & Nassawango River & 01485500 & Chesapeake Bay & 44.9 & 57.2 & 17.3 & 17.0 & 1.8 \\
\hline
\end{tabular}

discharge, and in the mid-Atlantic Coastal Plain, that fraction is typically at least 70 to 90 percent (Sanford and others, 2012). In this study, recharge could be estimated with enough certainty that the fluxes were already considered to be adequately constrained, and therefore, base flows were not included in the calibration procedure. In addition, the procedure used to estimate the recharge was based on the base-flow calculations obtained from the Coastal Plain of Maryland (Sanford and others, 2012). To ensure that the base flows were represented adequately by the assigned recharge rates, however, total runoff was estimated from eight watersheds across the peninsula (table 2). These watersheds were a subset of 12 watersheds on the peninsula that have real-time water data collected at stream gages (fig. 31). The remaining four watersheds did not have an adequate period of flow data with which to make a comparison to simulated flow. The simulated total runoff was calculated from the model output by adding the base flow calculated from the drain discharges within the watershed to the estimated surface runoff for the watershed (fig. 16). The simulated and measured total runoff were within 5 percent of each other for six of the watersheds; values differed by 12 and 25 percent in two watersheds the northeastern peninsula (table 2).

Groundwater ages based on environmental tracer concentrations are frequently used to calibrate either fluxes (such as recharge rates), effective porosity, or both (Sanford, 2011). In this study, recharge was specified and not calibrated, but groundwater age proved to be useful for validating the recharge rates and calibrating effective porosity. Several dozen ages had previously been calculated for groundwater in shallow wells across the peninsula (Dunkle and others, 1993). A subset of 24 of these wells (table 3) was used to calibrate effective porosity. Groundwater age ranged from 2 to 44 years in wells whose screens were between 11 and $65 \mathrm{ft}$ below land surface. Although several dozen ages were measured on the peninsula by Dunkle and others (1993), many of these were concentrated in a few local clusters; therefore, a subset of 24 age measurements was chosen to obtain the best spatial coverage possible. The areal distribution of these measurements across the peninsula (fig. 32) reflects three of the east-west cross sections used in the original study. Two of the measurements are located at the same site but at different depths (table 3).

Representing the numerous geologic units in the model grid required 35 different hydraulic conductivity values to be assigned during the calibration procedure (table 4). The model was originally run using the USGS parameter-estimation code UCODE (Poeter and others, 2005) in order to complete a rough sensitivity analysis. From this analysis, it was determined that only some of the hydraulic conductivity parameters affected simulated water levels strongly enough to allow for their parameters to be estimated. As a result, the remaining hydraulic conductivity values were specified based on best estimates from field data (table 4), and the values for the seven most prevalent and influential unit were calibrated by a combination of UCODE inverse estimation and trial and error. The final values of the calibrated parameters are listed in table 4 . The calibrated values were for the Kent Island Formation, the Omar Formation, the Beaverdam Sand, the Pensauken Formation, the Columbia Formation, the Aquia aquifer, and the Hornerstown Formation. All confining units were assigned a specified hydraulic conductivity value of 0.001 . Although actual values for these units may be smaller locally in the field, the value was sufficiently low for the purpose of estimating age distributions to the streams. Use of a smaller value created severe solver convergence problems, and the tiny fraction of very old water created using smaller values does not impact forecasting trends in nitrate fluxes to the streams because all groundwater more than several decades old is relatively nitrate free. The composite-scaled sensitivity (CSS) for each hydraulic conductivity parameter is listed in table 5. Parameters with large CSS values either had corresponding geologic units that were areally extensive or contained numerous observation wells completed within them. 


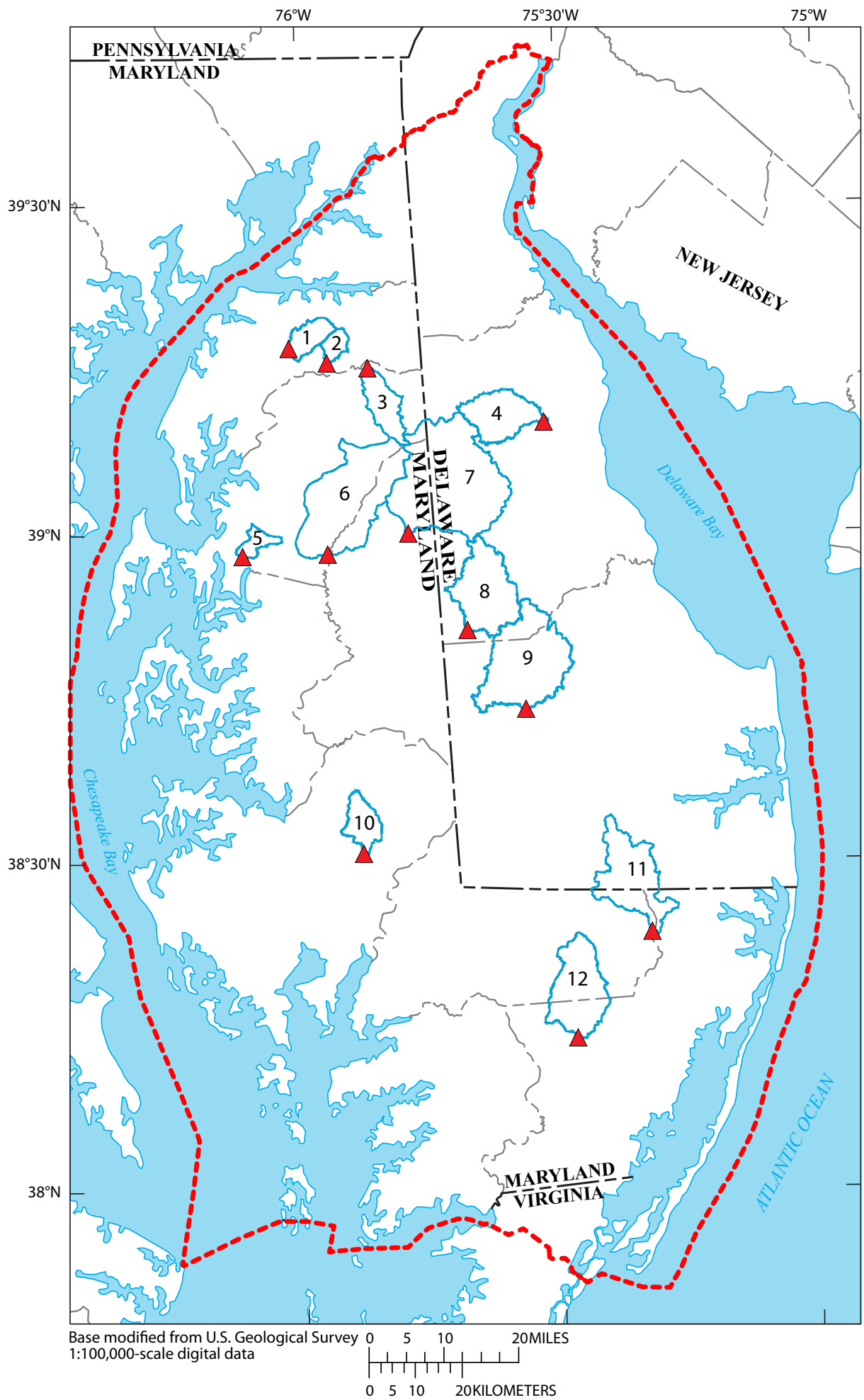

\section{EXPLANATION}

Watersheds with USGS gages

1. Morgan Creek (01493500)

2. Chesterville Branch (01493112)

3. Unicorn Branch (01493000)

4. St. Jones River (01483700)

5. Sallie Harris Creek (01492500)

6. Tuckahoe Creek (01491500)

7. Choptank River (01491000)

8. Marshyhope Creek (01488500)

9. Nanticoke River (01487000)

10. Chicamacomico River (01490000)

11. Pocomoke River (01485000)

12. Nassawango Creek (01485500)

Watershed boundary

Active model grid boundary

USGS stream gage with real-time data

Figure 31. Locations of U.S. Geological Survey stream gages and watersheds on the Delmarva Peninsula with real-time water data. 
Table 3. Observation wells and associated groundwater ages used for comparison with simulated groundwater ages in this study.

[Md., Maryland; Del., Delaware; ID, identifier]

\begin{tabular}{|c|c|c|c|c|c|c|c|c|c|c|c|c|c|}
\hline $\begin{array}{l}\text { Well } \\
\text { no. }\end{array}$ & $\begin{array}{l}\text { Local well } \\
\text { ID number }\end{array}$ & State & County & Latitude & Longitude & $\begin{array}{l}\text { Grid } \\
\text { row no. }\end{array}$ & $\begin{array}{c}\text { Grid } \\
\text { column } \\
\text { no. }\end{array}$ & $\begin{array}{l}\text { Well } \\
\text { depth, } \\
\text { in feet }\end{array}$ & $\begin{array}{c}\text { Land } \\
\text { surface } \\
\text { elevation }^{\mathrm{a}}\end{array}$ & $\begin{array}{c}\text { Grid } \\
\text { layer } \\
\text { no. }\end{array}$ & $\begin{array}{c}\text { Tracer- } \\
\text { based } \\
\text { age }^{\mathrm{b}} \text {, } \\
\text { in years }\end{array}$ & $\begin{array}{c}\text { Simulated } \\
\text { age, } \\
\text { in years }\end{array}$ & Error \\
\hline 2 & KE Bd 39 & Md. & Kent & $39^{\circ} 16^{\prime} 45^{\prime \prime}$ & $76^{\circ} 03^{\prime} 50^{\prime \prime}$ & 358 & 215 & 37 & 75 & 2 & 32.6 & 18.8 & 13.8 \\
\hline 3 & Hd 15-7 & Del. & New Castle & $39^{\circ} 19^{\prime} 38^{\prime \prime}$ & $75^{\circ} 40^{\prime} 14^{\prime \prime}$ & 320 & 438 & 19 & 68 & 2 & 18.2 & 17.2 & 1.0 \\
\hline 5 & KE Bg 35 & Md. & Kent & $39^{\circ} 19^{\prime} 57^{\prime \prime}$ & $75^{\circ} 49^{\prime} 06^{\prime \prime}$ & 318 & 354 & 50 & 62 & 3 & 8.0 & 18.5 & -10.5 \\
\hline 6 & KE Bg 65 & Md. & Kent & $39^{\circ} 16^{\prime} 08^{\prime \prime}$ & $75^{\circ} 59^{\prime} 43^{\prime \prime}$ & 365 & 254 & 20 & 49 & 2 & 4.0 & 7.0 & -3.0 \\
\hline 7 & KE Be 62 & Md. & Kent & $39^{\circ} 17^{\prime} 42^{\prime \prime}$ & $75^{\circ} 55^{\prime} 48^{\prime \prime}$ & 346 & 291 & 24 & 61 & 2 & 5.0 & 8.3 & -3.3 \\
\hline 8 & KE Be 162 & Md. & Kent & $39^{\circ} 17^{\prime} 42^{\prime \prime}$ & $75^{\circ} 55^{\prime} 48^{\prime \prime}$ & 346 & 291 & 65 & 61 & 3 & 36.0 & 28.8 & 7.2 \\
\hline 12 & QA Ed 39 & Md. & Queen Anne's & $38^{\circ} 55^{\prime} 55^{\prime \prime}$ & $76^{\circ} 07^{\prime} 54^{\prime \prime}$ & 611 & 179 & 24 & 60 & 2 & 11.0 & 7.0 & 4.0 \\
\hline 13 & TA Be 85 & Md. & Talbot & $38^{\circ} 54^{\prime} 40^{\prime \prime}$ & $76^{\circ} 02^{\prime} 44^{\prime \prime}$ & 626 & 229 & 21 & 45 & 2 & 9.0 & 7.2 & 1.8 \\
\hline 14 & CO De 146 & Md. & Caroline & $38^{\circ} 53^{\prime} 02^{\prime \prime}$ & $75^{\circ} 54^{\prime} 01^{\prime \prime}$ & 645 & 311 & 19 & 45 & 2 & 5.0 & 5.8 & -0.8 \\
\hline 15 & $\mathrm{Nd} 41-4$ & Del. & Sussex & $38^{\circ} 46^{\prime} 30^{\prime \prime}$ & $75^{\circ} 34^{\prime} 51^{\prime \prime}$ & 722 & 495 & 19 & 45 & 2 & 2.0 & 5.6 & -3.6 \\
\hline 16 & Og 43-2 & Del. & Sussex & $38^{\circ} 41^{\prime} 18^{\prime \prime}$ & $75^{\circ} 17^{\prime} 31^{\prime \prime}$ & 782 & 660 & 19 & 44 & 2 & 5.0 & 12.3 & -7.3 \\
\hline 17 & $\mathrm{Nb} 24-3$ & Del. & Sussex & $38^{\circ} 48^{\prime} 37^{\prime \prime}$ & $75^{\circ} 41^{\prime} 52^{\prime \prime}$ & 697 & 427 & 12 & 38 & 1 & 15.0 & 4.5 & 10.5 \\
\hline 18 & DO Ce 89 & Md. & Dorchester & $38^{\circ} 31^{\prime} 23^{\prime \prime}$ & $76^{\circ} 03^{\prime} 13^{\prime \prime}$ & 909 & 227 & 16 & 12 & 2 & 44.0 & 18.2 & 25.8 \\
\hline 19 & DO Cg 45 & Md. & Dorchester & $38^{\circ} 32^{\prime} 18^{\prime \prime}$ & $75^{\circ} 52^{\prime} 28^{\prime \prime}$ & 897 & 329 & 48 & 18 & 3 & 33.0 & 788.2 & -755.2 \\
\hline 20 & WI Be 52 & Md. & Wicomico & $38^{\circ} 26^{\prime} 44^{\prime \prime}$ & $75^{\circ} 36^{\prime} 12^{\prime \prime}$ & 962 & 485 & 47 & 47 & 3 & 11.0 & 22.1 & -11.1 \\
\hline
\end{tabular}

${ }^{\text {a} E l e v a t i o n s ~ a r e ~ i n ~ f e e t ~ a b o v e ~ N G V D ~} 29$.

${ }^{b}$ Data from Dunkle and others (1993). 


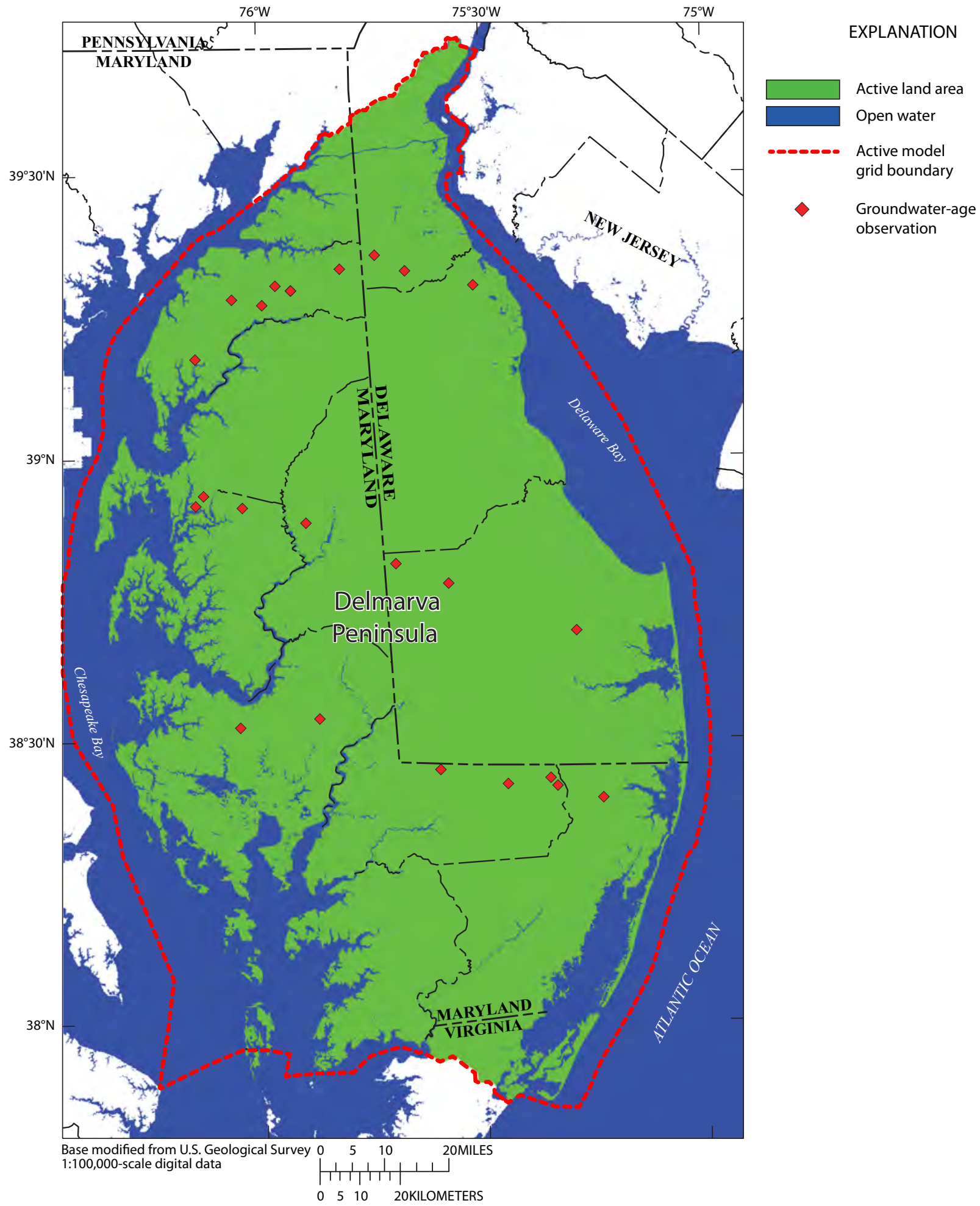

Figure 32. Locations of the 23 well sites where samples were collected for groundwater-age observations. 
Table 4. Hydraulic conductivity values reported and specified or calibrated in the groundwater model in this study.

[ $\mathrm{ft}^{2} / \mathrm{d}$, foot squared per day; nd, no data acquired or reported]

\begin{tabular}{|c|c|c|c|c|c|c|c|}
\hline $\begin{array}{c}\text { Unit } \\
\text { number }\end{array}$ & $\begin{array}{l}\text { Stratigraphic or } \\
\text { hydrogeologic } \\
\text { unit name }\end{array}$ & $\begin{array}{l}\text { Map symbol } \\
\text { used in this } \\
\text { report }\end{array}$ & $\begin{array}{c}\text { Mean } \\
\text { reported } \\
\text { value of } \\
\text { transmissivity, } \\
\text { in } \mathrm{ft}^{2} / \mathrm{d}^{\mathrm{a}}\end{array}$ & $\begin{array}{l}\text { Number of } \\
\text { values } \\
\text { reported }\end{array}$ & $\begin{array}{c}\text { Mean } \\
\text { thickness, } \\
\text { in feet }\end{array}$ & $\begin{array}{c}\text { Average } \\
\text { hydraulic } \\
\text { conductivity, } \\
\text { in feet per day }\end{array}$ & $\begin{array}{c}\text { Value of } \\
\text { hydraulic } \\
\text { conductivity } \\
\text { used in model, } \\
\text { in feet per dayb }\end{array}$ \\
\hline 1 & Kent Island Formation & Qki & nd & nd & nd & nd & 1 \\
\hline 2 & Parsonsburg sand & Qpr & nd & nd & 20 & nd & 50 \\
\hline 4 & Walston silt & Qws & nd & nd & 20 & nd & 1 \\
\hline 5 & Beaverdam sand & Qbv & nd & nd & 75 & nd & 75 \\
\hline 6 & Pensauken Formation & Qpe & 8,500 & 26 & 50 & 170 & 100 \\
\hline 7 & Columbia Formation & Qco & nd & nd & 50 & nd & 10 \\
\hline 8 & Upper Chesapeake Confining Unit UC1 & Tuch1 & nd & nd & 90 & nd & 0.001 \\
\hline 12 & Upper Chesapeake Confining Unit UC3 & Tuch3 & nd & nd & 30 & nd & 0.001 \\
\hline 13 & Manokin aquifer & Tma & 570 & 7 & 110 & 20 & 25 \\
\hline 14 & St. Mary's confining unit & Tsm & nd & nd & 150 & nd & 0.001 \\
\hline 15 & Choptank aquifer & Tch & nd & nd & 100 & nd & 1 \\
\hline 16 & Lower Chesapeake confining unit & Tlch & nd & nd & 60 & nd & 0.001 \\
\hline 17 & Calvert aquifer system & Tca & 1,656 & 11 & 240 & 7 & 1 \\
\hline 18 & Calvert confining unit & Tcc & 1 & 18 & 90 & 0.008 & 0.001 \\
\hline 19 & Piney Point aquifer & Tpp & 3,700 & 17 & 100 & 37 & 50 \\
\hline 26 & Matawan aquifer & Kma & nd & nd & nd & nd & 20 \\
\hline 27 & Matawan-Magothy confining unit & $\mathrm{Kmm}$ & 0 & 1 & 120 & 0.000 & 0.001 \\
\hline 28 & Magothy aquifer & Kmg & 3,800 & 33 & 52 & 73 & 20 \\
\hline 29 & Magothy-Patapsco confining unit & Kmp & 0 & 3 & 70 & 0.003 & 0.001 \\
\hline 30 & Upper Patapsco aquifer & Kup & 2,000 & 25 & 400 & 5 & 20 \\
\hline 31 & Patapsco confining unit & $\mathrm{Kpc}$ & 0 & nd & 150 & 0.000 & 0.001 \\
\hline 32 & Lower Patapsco aquifer & Klp & 1,754 & 41 & 550 & 3 & 20 \\
\hline 33 & Arundel Clay confining unit & $\mathrm{Kac}$ & nd & nd & 300 & nd & 0.001 \\
\hline 34 & Patuxent aquifer & $\mathrm{Kpx}$ & 1,142 & 39 & 1,200 & 1 & 10 \\
\hline 35 & Pre-Cretaceous crystalline & $\mathrm{pK}$ & nd & nd & nd & nd & 1 \\
\hline
\end{tabular}

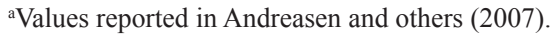

${ }^{b}$ Numbers in bold-italic were calibrated; those not in bold-italic were specified. 
Table 5. Composite scaled sensitivities for hydraulic conductivity parameters in the groundwater model.

[CSS, Composite Scaled Sensitivity]

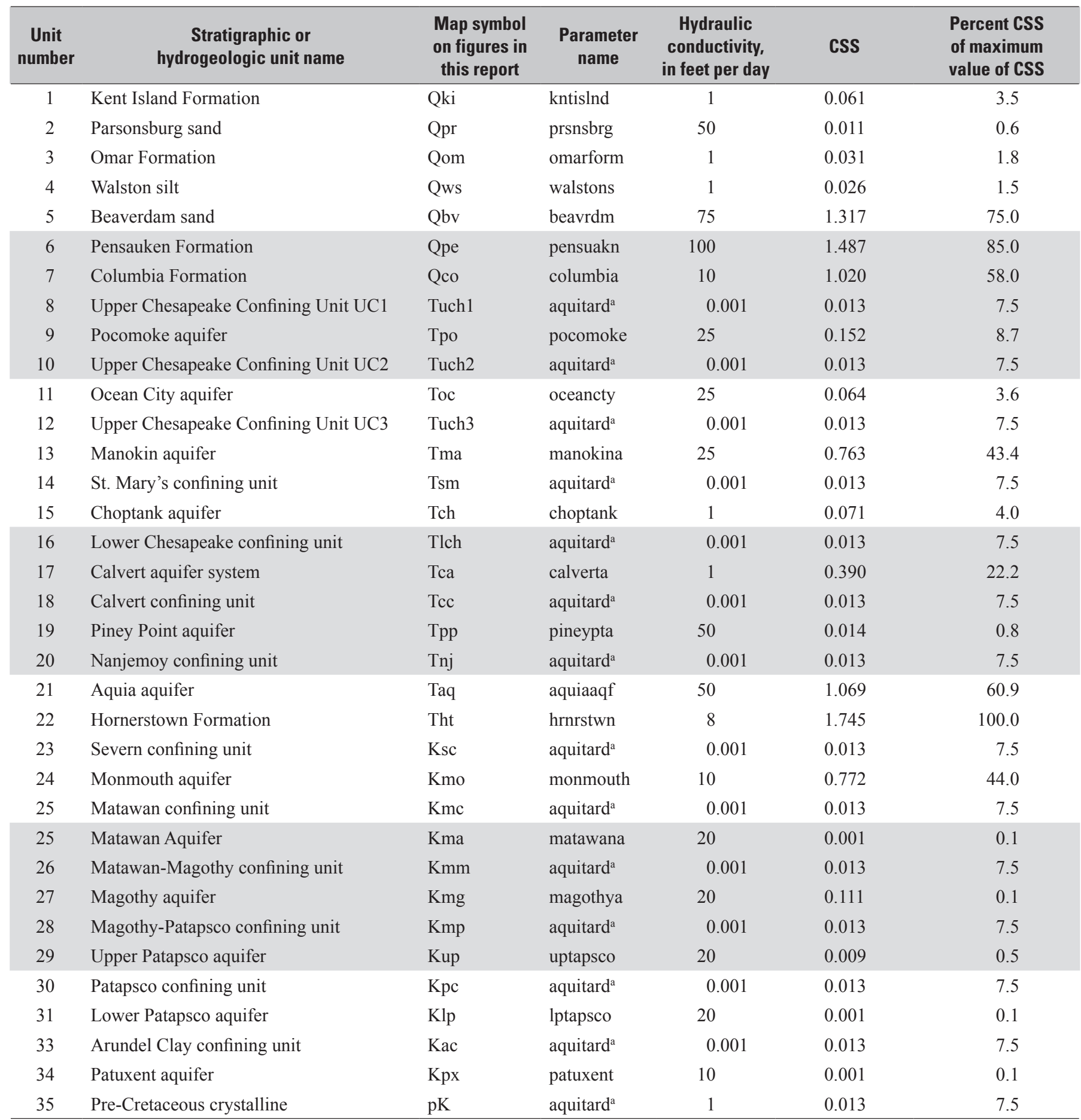

${ }^{a}$ The aquitard parameter is a combination of all of the confining units, and thus the CSS respresents this composite of units. 
The final calibrated model produced a set of simulated water levels that were then compared to the observed water levels (fig. 33). The fit to the data is shown in figure $33 \mathrm{~A}$, with the largest single error being $24 \mathrm{ft}$ (fig. $33 B$ ). Errors can be attributed to local variations in hydraulic conductivity that cannot be represented by assigning a constant value for each formation for the entire peninsula. Thus, although the error between observed and simulated water-level values could potentially be high at the local cell level, the overall system (and especially fluxes) is represented in a manner appropriate for estimating the age distributions in streams, which is the intended use of this model. The distribution of the error in the simulated water-level observations does not show any obvious spatial trend in observed error (fig. 34).

Groundwater ages were simulated for each of the corresponding observation wells using backward tracking of particles in the USGS code MODPATH (Pollock, 1994). The resulting plot of observed and simulated advective age (fig. 35) reveals a distribution that is not highly correlated, but this pattern is typical of simulated groundwater-age observations (Sanford, 2011). Flow direction and age vary greatly at this scale, which is typically too small for age to be simulated in adequate detail by the flow model; therefore, a general fit to the mean and range of groundwater ages is usually sought as an indicator of reasonable fit. In this case, the mean observed age was 11 years and the mean simulated age was 11.5 years. Simulated age ranged from 3 to 42 years (except for one outlier), which was very close to the range of 2 to 45 years for the observed values. The outlier can be explained by the fact that the tritium-helium-based tracer at that particular observation was near its limit of about 40 to 50 years. Thus, because it is possible that given water sampled from wells can represent a mixture of ages (Cook and Herzceg, 2000), the groundwater at this observation location may easily have a substantial percentage of water much older than 40 to 50 years, such as that suggested by the simulated age of 755 years.

The final simulated ages were calculated after adjusting porosity to achieve the best fit for the mean age. This adjustment yielded a calibrated effective porosity of 35 percent for the entire system. This value is very reasonable for the sediments on the Coastal Plain because measured total porosity, which will be greater than the effective porosity, is typically between 40 and 50 percent for the Quaternary (least compacted) sediments (Sanford and Pope, 2009). The spatial distribution of simulated ages does not show any obvious spatial trend in error (fig. 36).

\section{Simulation Results}

The primary result of the flow model in this study is a distribution of hydraulic head (groundwater levels) that represents the steady-state flow condition. The water levels in layer 1 of the model (fig. 37) most closely represent the elevation of the water table, which for most of the peninsula, strongly reflects the topography. Water levels in the deepest part of the model grid, at $245 \mathrm{ft}$ below land surface in layer 7 , are a slightly subdued replica of the water table (fig. 38) because the groundwater system simulated here is very thin (300 ft) compared to its areal extent (tens of miles) and controlled mostly by local variation in topography. The water table is close to land surface (within $3 \mathrm{ft}$ ) over much of the peninsula (fig. 39), especially in low-lying areas near the bays. Marshy areas in the center of the peninsula in Delaware and southeastern Maryland also have very shallow water tables. The areas that have deeper water tables (more than $10 \mathrm{ft}$ ) are typically located along the upper topographic rims of incised stream valleys, especially in the northeastern peninsula, which has the most deeply incised valleys.

Information can also be obtained by examining the overall water budget of the model. The post-processing code ZONEBUDGET (Harbaugh, 1990) was used to analyze the spatial water budget for the model. A layer-by-layer analysis (table 6) revealed that much of the flow is concentrated in the upper part of the model grid (shallowest part of the flow system), with two-thirds of the flow occurring in the top 10 percent of the model grid and 90 percent of the flow occurring in the top half of the model grid. Although the mean recharge to the peninsula is $3,320 \mathrm{Mgal} / \mathrm{d}$, only $56 \mathrm{Mgal} / \mathrm{d}$ exits by submarine groundwater discharge (less than 2 percent of the total discharge); the remainder discharges in the stream valleys. By dividing the total water volume of each layer (using the calibrated porosity of 0.35 ) by the total flux in each layer, mean residence times were obtained for each layer. The higher flows in the upper layers are reflected in these residence times, which range from 2.5 years for layer 1 to over 900 years for layer 7. ZONEBUDGET was also used to apportion the fluxes by geologic unit (table 7). The highest fluxes are in those aquifers with the broadest areal extent, and the lowest fluxes are in the deeper units and those with a limited areal extent. Water volumes and residence times were also calculated for the geologic units. In general, the units with the shortest residence times are the shallowest Quaternary units, and those with the longest residence times are the confining units, especially the deeper ones.

Other useful information can be obtained by directly analyzing the fluxes between cells from the final head distribution. One example is the distribution of net recharge (or discharge) across the peninsula (fig. 40). As described earlier in the report, the land-surface boundary condition was treated as a combination of specified recharge and a seepage face. The net recharge can be calculated by subtracting the drain discharge at each cell from its specified value of recharge. Plotting this net recharge areally yields the locations and magnitudes of net groundwater discharge. These discharge locations, shown in red in figure 40 , are in stream valleys where base flow to the streams occurs. In the broad marshy areas, nearly all of the specified recharge is calculated by the model to discharge again within, or close to, the same cell at land surface (representing riparian ET), resulting in a net recharge of nearly zero.

Another important example of flux-related information obtained from the simulation results is the residence time of 

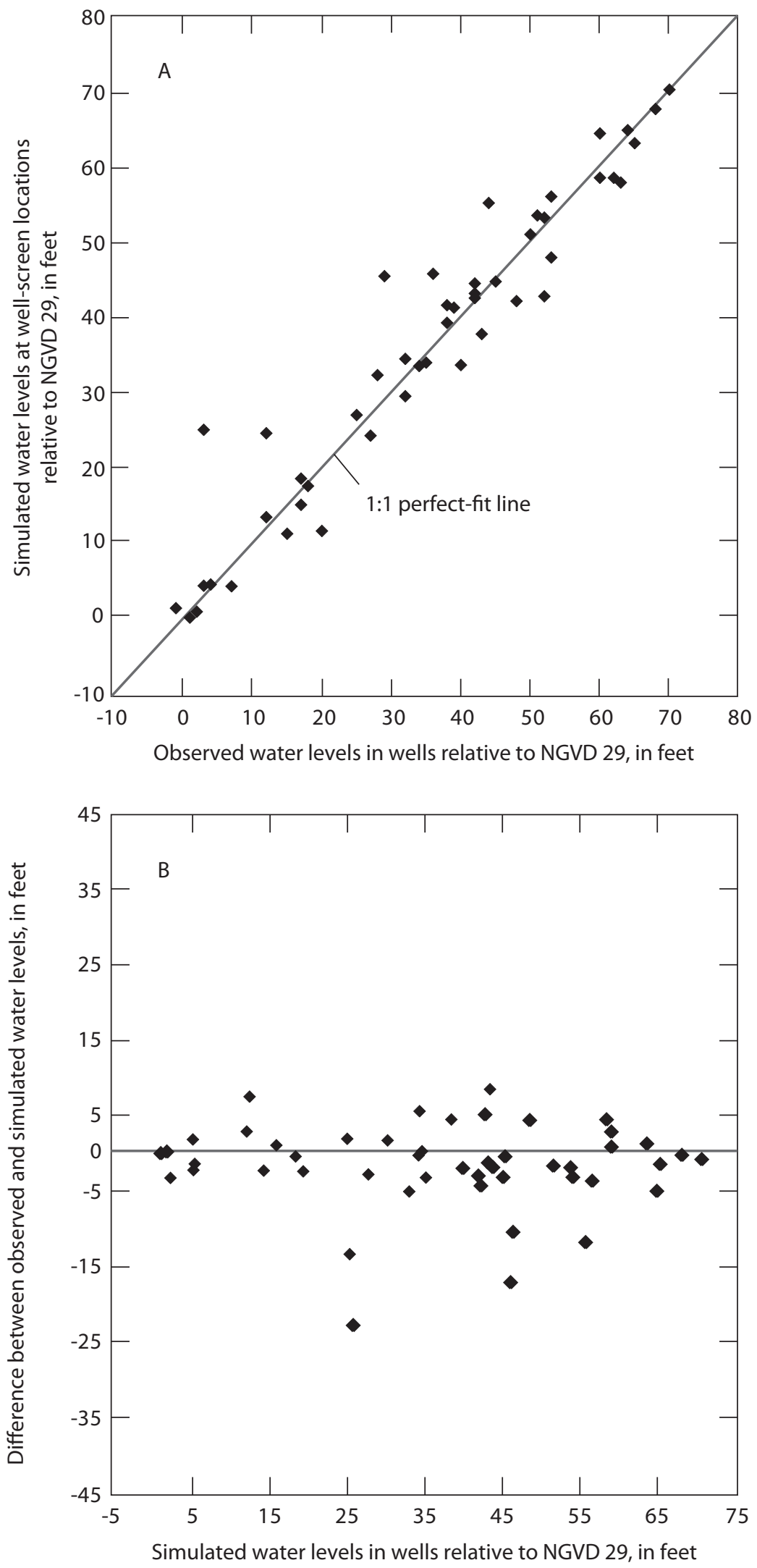

Figure 33. $A$, Observed versus simulated water levels, and $B$, simulated water levels versus the difference between the observed and simulated water levels. 


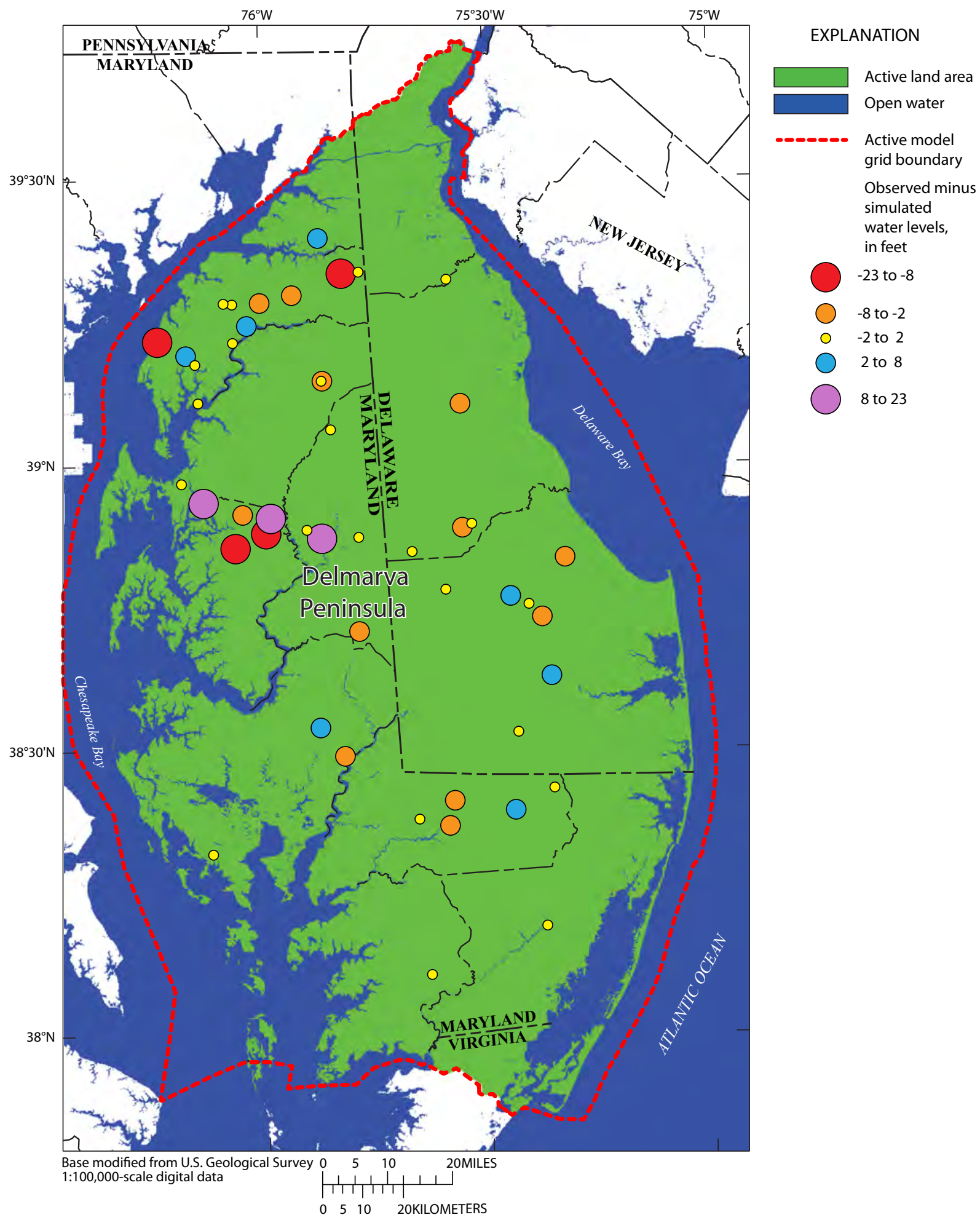

Figure 34. Spatial distribution of errors in the simulated water-level observations. 

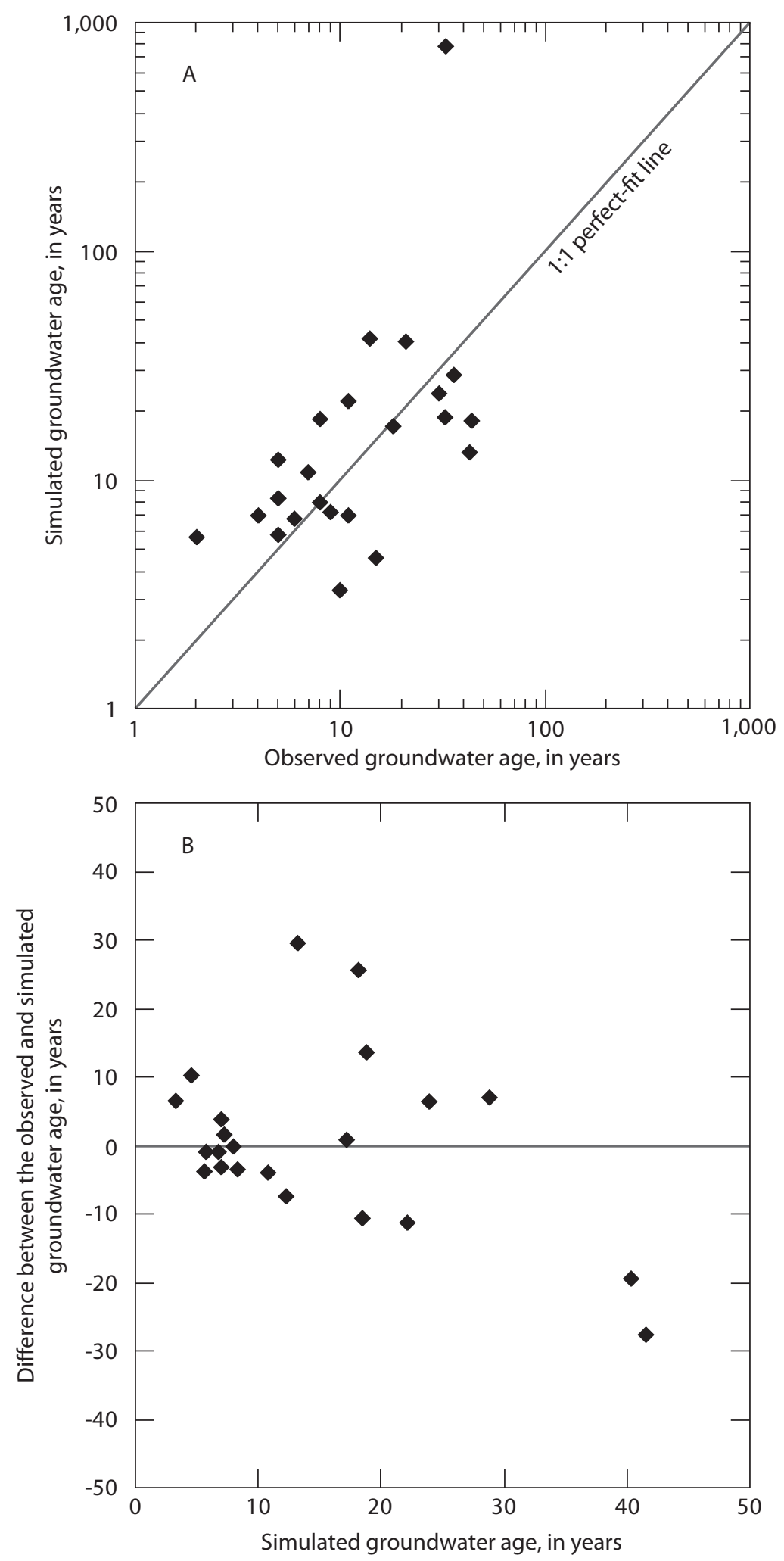

Figure 35. A, Observed versus simulated groundwater ages, and $B$, simulated ages versus the difference between the observed and simulated ages. 


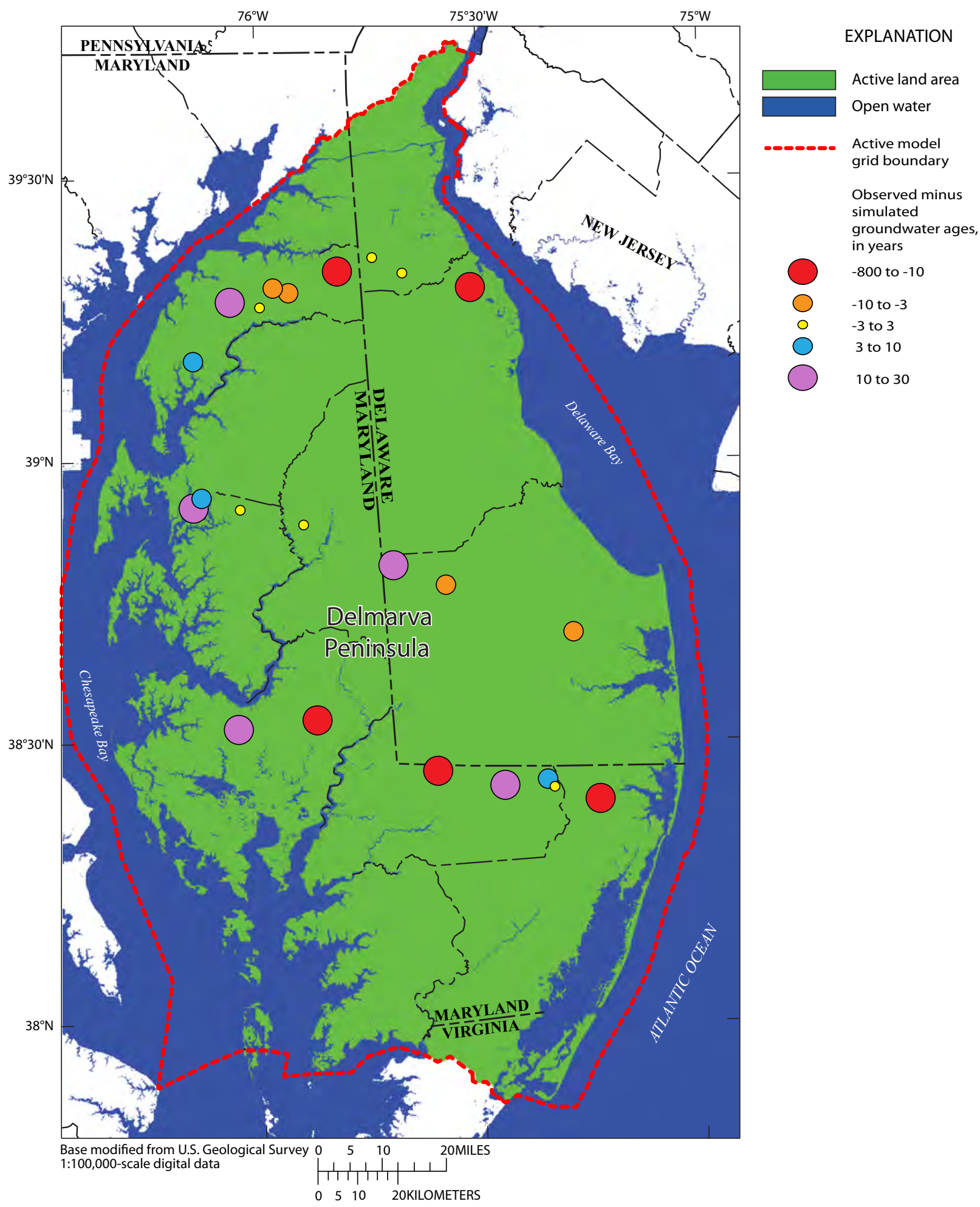

Figure 36. Spatial distribution of errors in the simulated age observations. 


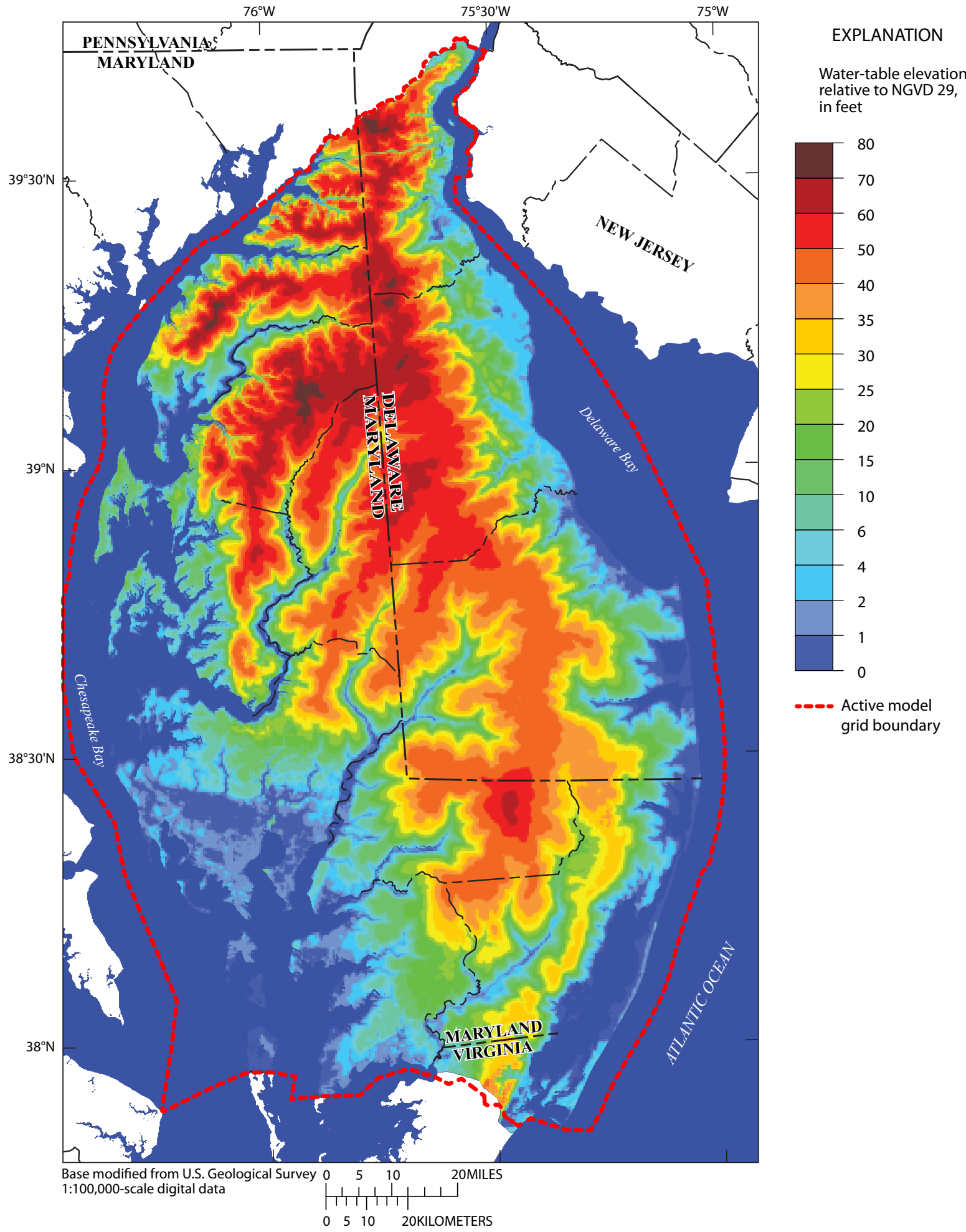

Figure 37. The simulated water table on the Delmarva Peninsula represented by water levels in layer 1 of the model. 


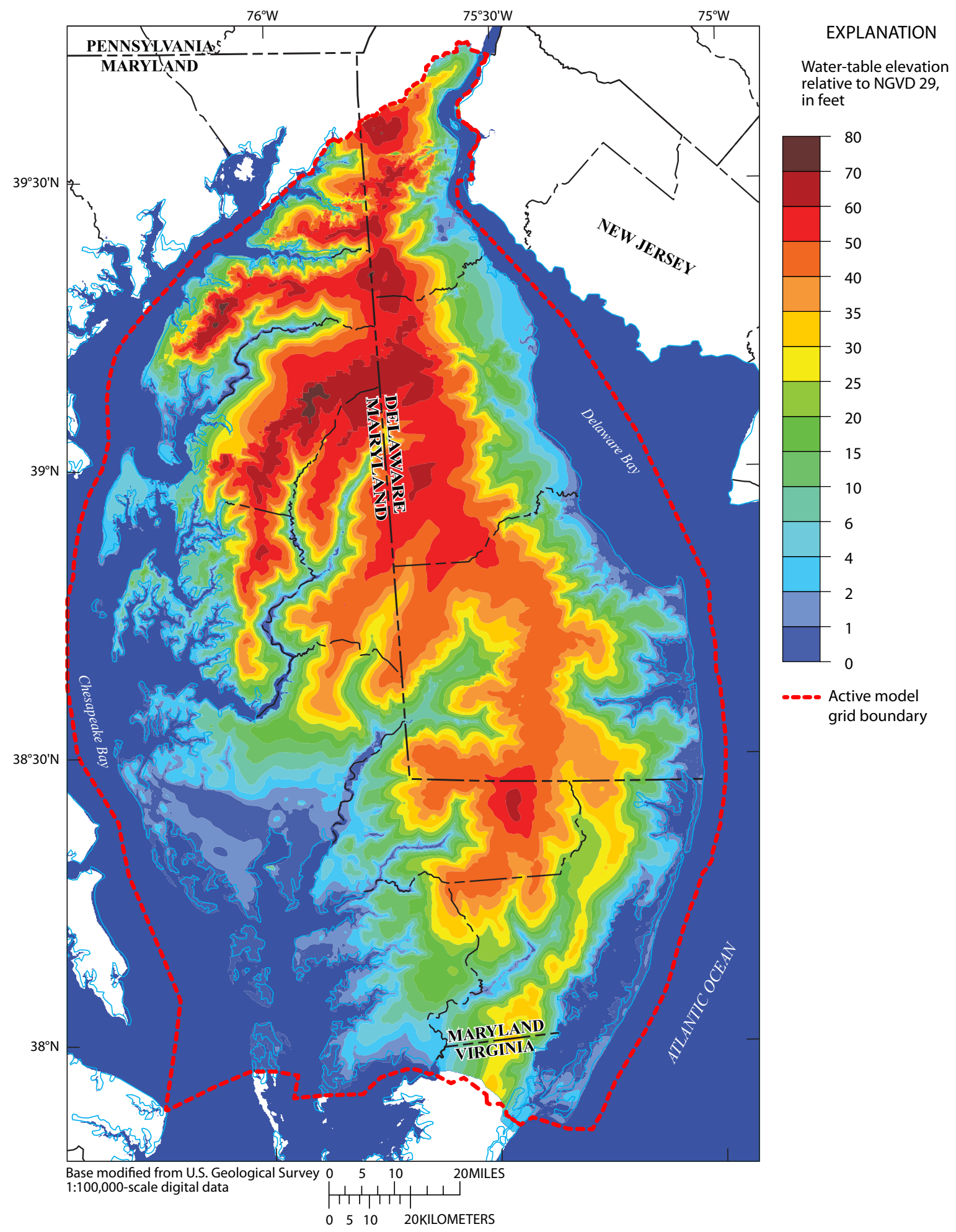

Figure 38. The simulated water levels in layer 7 of the model. 


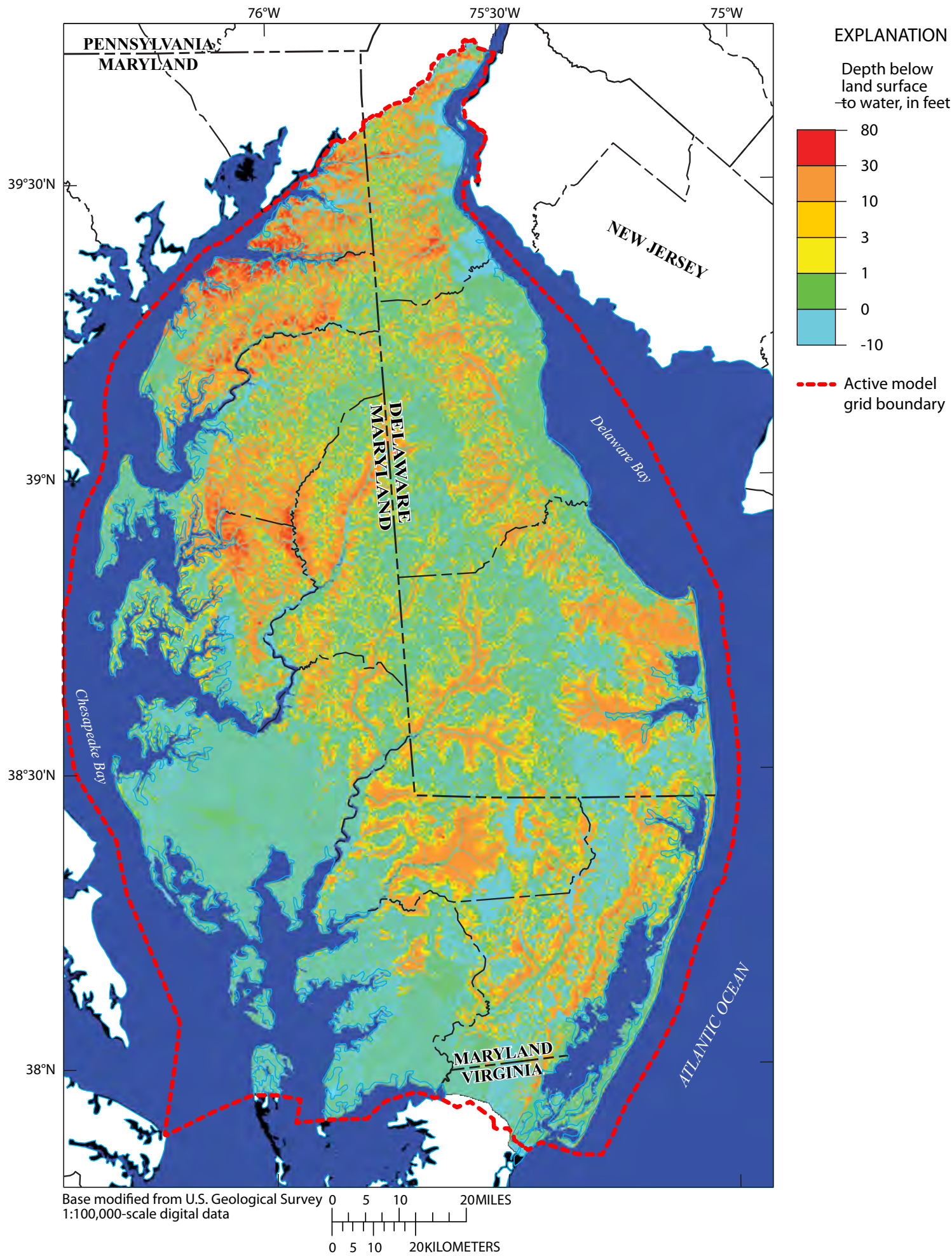

Figure 39. The simulated depth of the water table beneath the land surface. Negative values represent artesian conditions. 
Table 6. Water budget terms in the groundwater model by model layer.

[Mgal/d, millions of gallons per day; SGD, submarine groundwater discharge; Bgal, billions of gallons]

\begin{tabular}{|c|c|c|c|c|c|c|c|c|c|}
\hline \multirow[b]{2}{*}{$\begin{array}{l}\text { Layer } \\
\text { number }\end{array}$} & \multicolumn{2}{|c|}{ Inflows, in Mgal/d } & \multicolumn{3}{|c|}{ Outflows, in Mgal/d } & \multirow[b]{2}{*}{$\begin{array}{l}\text { Total flux, } \\
\text { in Mgal/d }\end{array}$} & \multirow[b]{2}{*}{$\begin{array}{l}\text { Percentage } \\
\text { of total flux }\end{array}$} & \multirow[b]{2}{*}{$\begin{array}{c}\text { Volume of } \\
\text { water, } \\
\text { in Bgal }\end{array}$} & \multirow{2}{*}{$\begin{array}{c}\text { Mean } \\
\text { residence } \\
\text { time of water, } \\
\text { in years }\end{array}$} \\
\hline & Recharge & $\begin{array}{l}\text { From other } \\
\text { layers }\end{array}$ & $\begin{array}{l}\text { To other } \\
\text { layers }\end{array}$ & $\begin{array}{l}\text { To drain } \\
\text { cells }\end{array}$ & $\begin{array}{l}\text { Net to } \\
\text { seafloor } \\
\text { (SGD) }\end{array}$ & & & & \\
\hline 1 & 3,320 & 2,117 & 2,117 & 3,264 & 56 & 5,437 & 40.4 & 5,034 & 2.5 \\
\hline 2 & 0 & 3,520 & 3,520 & 0 & 0 & 3,520 & 26.1 & 9,982 & 7.8 \\
\hline 3 & 0 & 2,158 & 2,158 & 0 & 0 & 2,158 & 16.0 & 15,104 & 19 \\
\hline 5 & 0 & 674 & 674 & 0 & 0 & 674 & 5.0 & 25,297 & 103 \\
\hline 6 & 0 & 385 & 385 & 0 & 0 & 385 & 2.9 & 30,208 & 215 \\
\hline 7 & 0 & 133 & 133 & 0 & 0 & 133 & 1.0 & 45,313 & 932 \\
\hline Total & 3,320 & & & 3,264 & 56 & 13,507 & & 151,000 & 125 \\
\hline
\end{tabular}

the groundwater within the flow system. This residence time is the primary object of concern with respect to the transport of nitrate from the infiltration point at land surface to Chesapeake Bay, and obtaining these results is the main objective of this study. The residence time can be viewed from two different perspectives. The first is from the perspective of groundwater age at any location in the flow system. This is calculated from the model results by using MODPATH to track a flow pathline backward from every cell of interest in the model to its recharge location at the water table, calculate its time of travel (age), and then plot each age according to its starting cell location. When this is done for layer 4 across the entire model area, a map of groundwater age $80 \mathrm{ft}$ below land surface is produced (fig. 41). The ages range from less than 30 years to more than 1,000 years. There are two main controls on the age at these depths - the location within the local flow system and the hydraulic conductivity of the geologic unit that is represented locally at the cell. The youngest waters are located near recharge areas that are also close to local streams. The oldest waters are in confining units, where flow rates are small. As a result, these old waters only contribute minimally to streamflow compared to waters in shallower, more permeable sediments.

The second perspective from which to view residence time is return time, which is the time required for groundwater to flow from the water table where it is recharged to the land surface as discharge to a surface-water body. These return times were calculated using MODPATH by tracking a particle forward from the water table at each cell to its discharge location and then calculating the associated time of travel (return time). This time of travel is mapped for each starting location to yield a map of groundwater return times (fig. 42). Such a map reveals that the peninsula is dominated by local flow systems controlled by the drainage network, and that return times vary consistently from less than 3 years in the stream valley to more than 100 years near the stream divides. These return times can be used to determine the age distribution of groundwater contributed to individual streams, which in turn can be used to predict the potential lag time between changes in the loading of nitrate at land surface and the resulting changes in nitrate concentrations in the streams.

The limitations of the model should be considered when interpreting or applying the results to other studies or to management decisions. These limitations are not likely to change the overall results, but may create errors more locally. These limitations include (1) anthropogenic stresses were not simulated, (2) calibration was made directly only to water-level and age observations (although base-flow observations were used to calibrated the specified recharge rates), (3) many local areas were not represented by water-level or age observations, (4) the bottom of the model is treated as a no-flow boundary, (5) long-term climate conditions were not considered (only a 30-year climate record was used to calibrate recharge), (6) only the impervious surface distribution from 2001 was used, and (7) variable-density effects on flow near the coastline were not simulated.

\section{Summary and Conclusions}

In this study, the U.S. Geological Survey (USGS) constructed a groundwater flow model for the Delmarva Peninsula including Delaware, Maryland and the northernmost section of Virginia. The model was constructed to simulate shallow groundwater flow system in the peninsula so that predictions can ultimately be made about the magnitude and variability of the lag time for nitrate between its application at land surface and its discharge into streams and Chesapeake Bay. The model was constructed and simulated using the newly released Newton version of the USGS code MODFLOW. A recharge value was specified at land surface based on a water-balance method used recently for the Coastal Plain that also incorporates a climate-regression equation for estimating evapotranspiration. 
Table 7. Water budget terms in the groundwater model by geologic unit.

[Mgal/d, millions of gallons per day; SGD, submarine groundwater discharge; Bgal, billions of gallons]

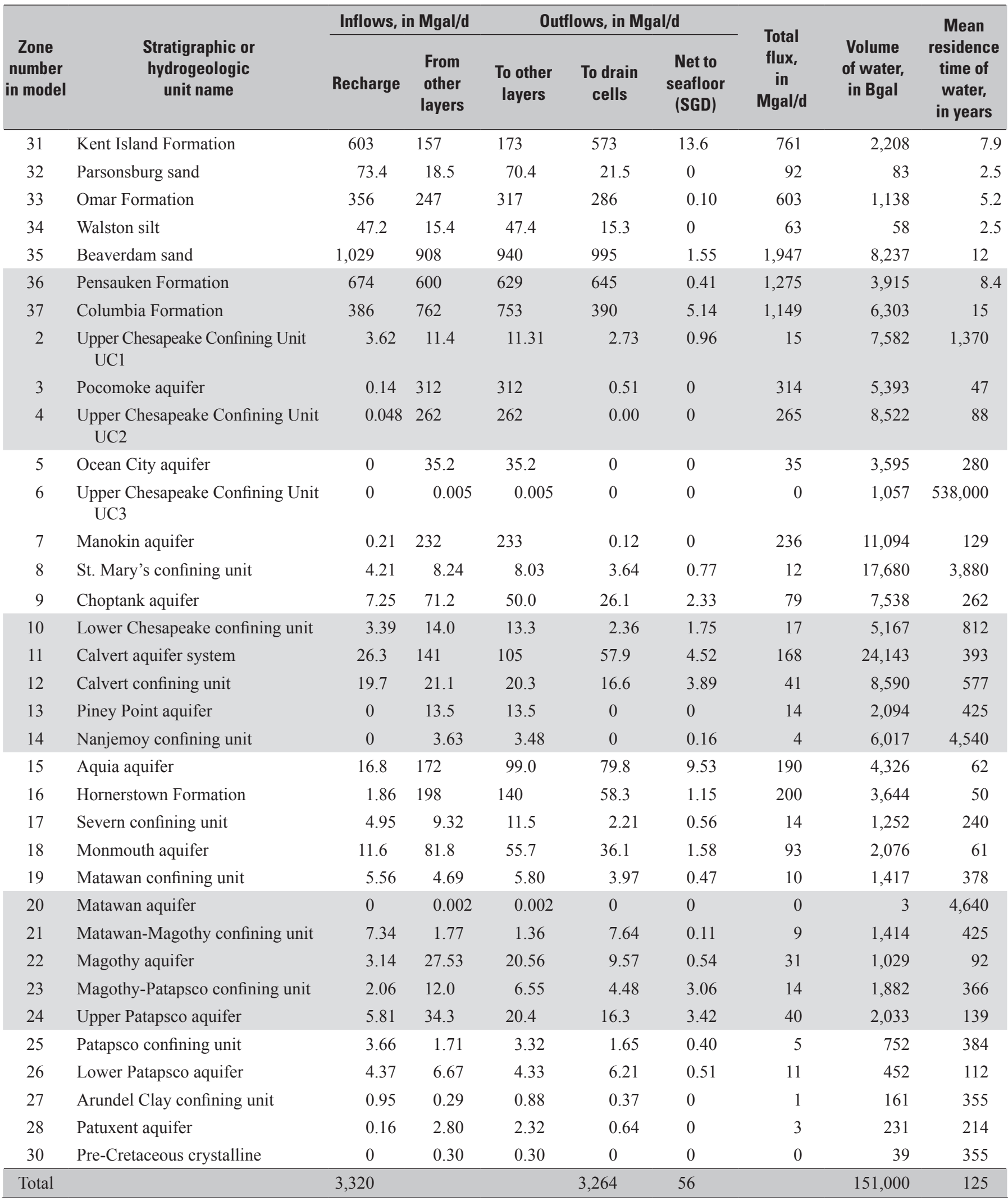




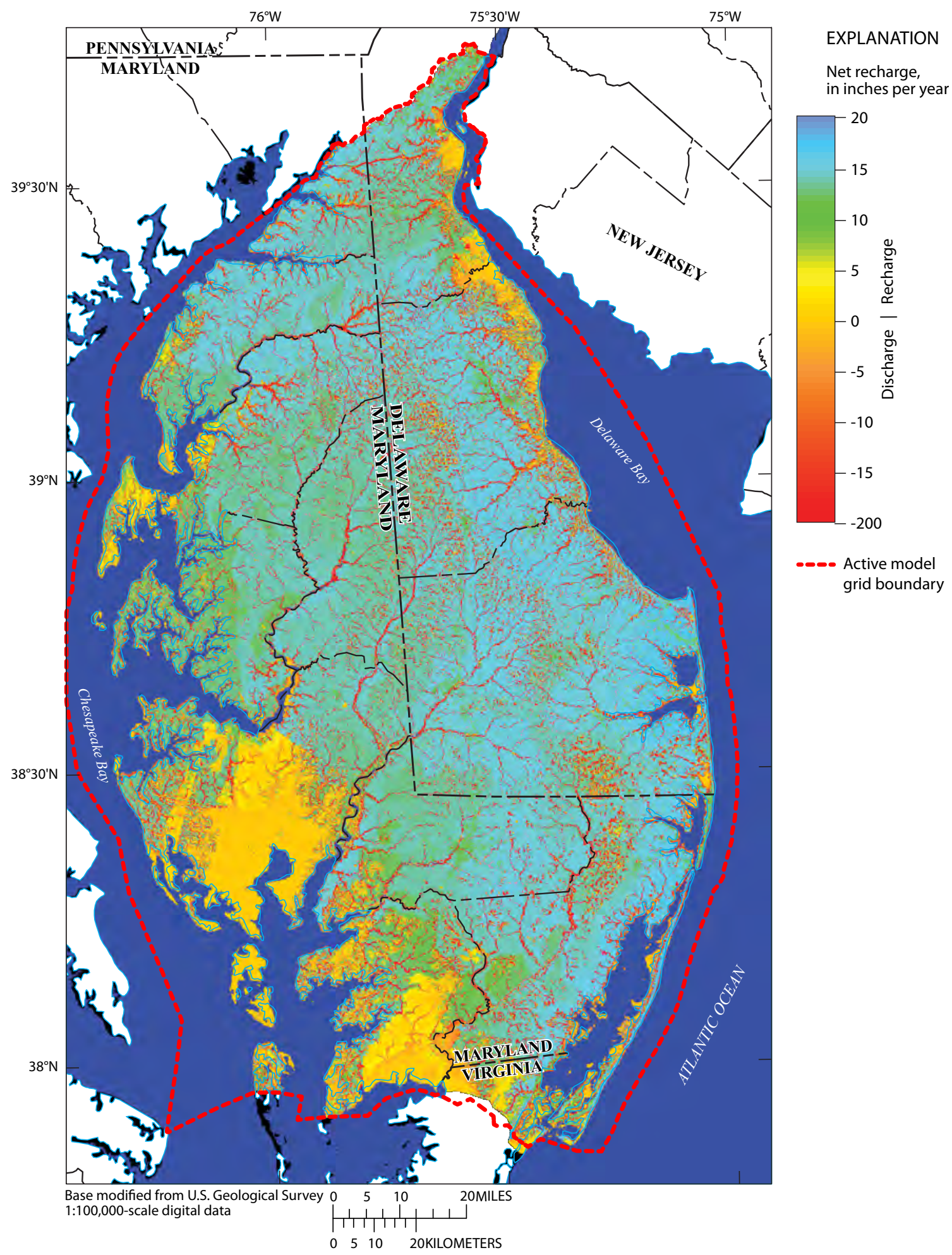

Figure 40. Simulated net recharge across the Delmarva Peninsula calculated by subtracting the seepage (drain) discharge from the recharge (fig. 18). 


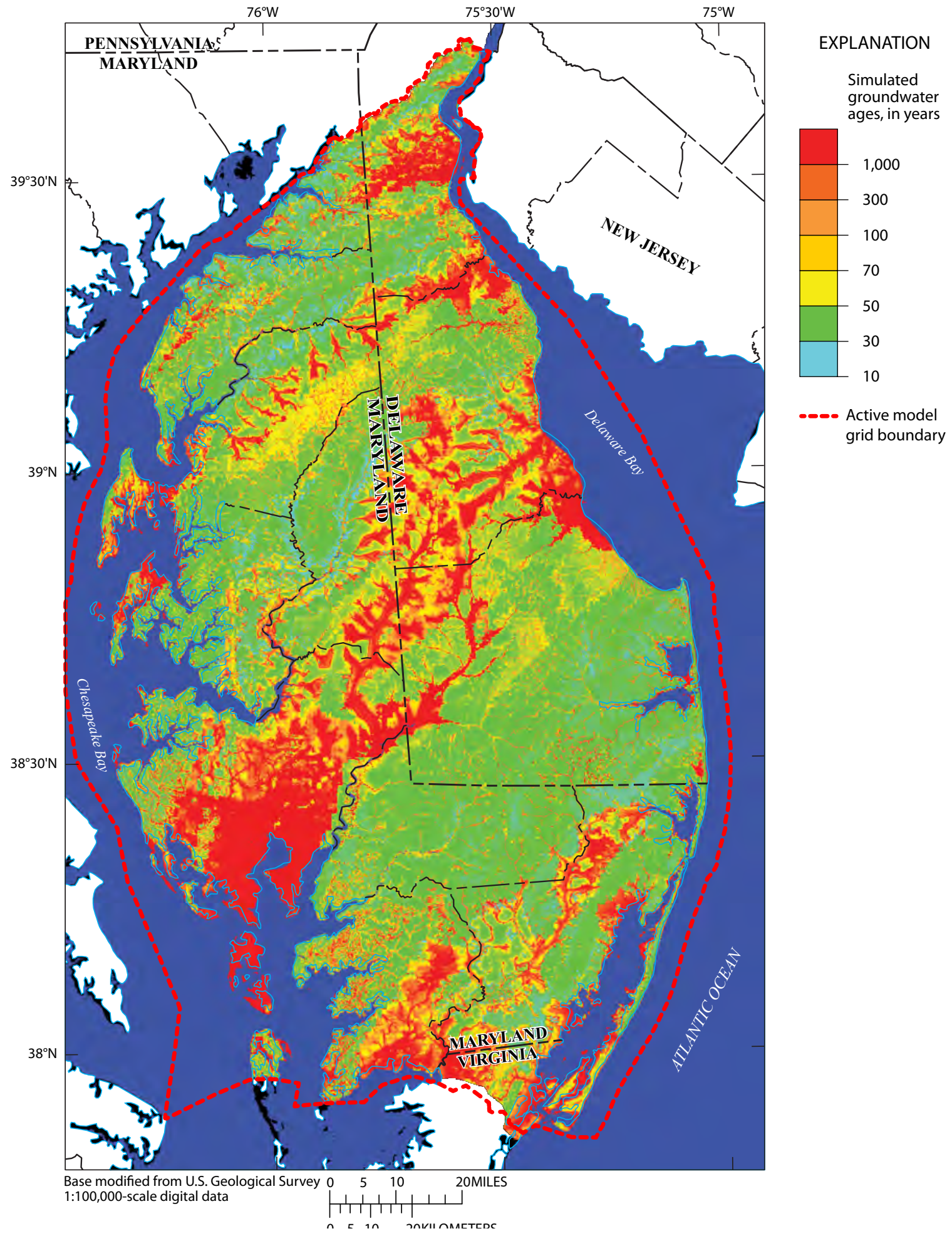

Figure 41. Simulated groundwater age 80 feet below land surface in layer 4 of the model grid. 


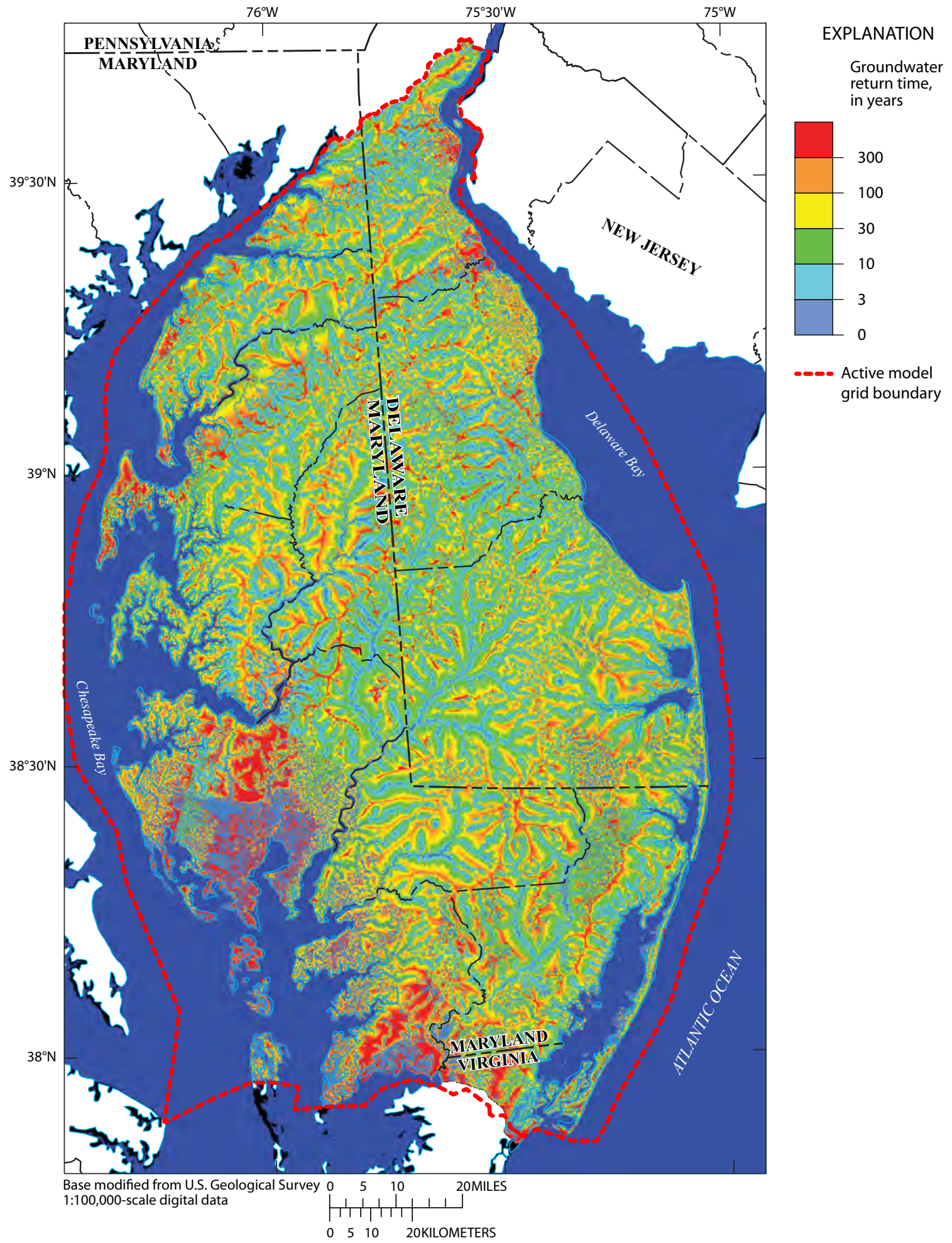

Figure 42. Simulated return time of groundwater travelling from the water table to its discharge location. 
Seepage to streams as base flow was simulated with the drain package in MODFLOW by assigning drains to every active cell in the top layer with an elevation above NGVD 29. A hydrogeologic framework for the Coastal Plain sediments constructed by Andreasen and coworkers at the Maryland Geological Survey was incorporated into the model grid. Hydraulic conductivity values were assigned mostly based on reported field values, but seven values for the most prevalent and influential units were calibrated to a best fit using 48 groundwater levels in shallow wells across the peninsula. Groundwater ages were calculated using MODPATH and compared to tracer-based ages from 24 wells, and the difference between the mean simulated and mean observed age was minimized to yield a calibrated effective porosity for the entire system of 35 percent.

Results of the simulation reveal a water table that closely reflects the land surface topography, with depths to water greater than 10 feet being located only in upland locations that are adjacent to incised stream valleys. The shallow nature of this flow system relative to its spatial extent results in groundwater flow that is controlled mostly by the local topography. Most of the water that is recharged remains within its local flow system until it is discharged to a local stream. Groundwater ages and return times were calculated using MODPATH for every cell in the model. Mapped groundwater ages illustrate the local nature of the flow systems and the very slow movement of water through the confining units. A map of the groundwater return time illustrates that most groundwater reaches a stream between 3 and 100 years after it is recharged to the water table, with a strong positive correlation existing between the return time and the distance between the point of recharge and the nearest stream.

\section{References Cited}

Andreasen, D.C., Achmad, G., Staley, A.W., and Hodo, R.M., 2007, Hydrogeologic framework of the Maryland Coastal Plain: Maryland Geological Survey and Maryland Department of Natural Resources Progress Report, 72 p.

Ator, S.W., Denver, J.M., Krantz, D.E., Newell, W.L., and Martucci, S.K., 2005, A surficial hydrogeologic framework for the Mid-Atlantic Coastal Plain: U.S. Geological Survey Professional Paper 1680, 44 p., 4 pls.

Bachman, L.J., and Wilson, J.M., 1984, The Columbia aquifer of the Eastern Shore of Maryland: Maryland Geological Survey Report of Investigations No. 40, 144 p.

Böhlke, J.K., and Denver, J.M., 1995, Combined use of groundwater dating, chemical, and isotopic analyses to resolve the history and fate of nitrate contamination in two agricultural watersheds, Atlantic Coastal Plain, Maryland: Water Resources Research, v. 31, no. 9, p. 2319-2339.
Cook, P.G., and Herzceg, A.L., 2000, Environmental tracers in subsurface hydrology: Boston, Kluwer Academic Publishers, $529 \mathrm{p}$.

Daly, C., Halbleib, M., Smith, J.I., Gibson, W.P., Doggett, M.K., Taylor, G.H., Curtis, J., and Pasteris, P.P., 2008, Physiographically-sensitive mapping of temperature and precipitation across the conterminous United States: International Journal of Climatology, v., 28, p. 2031-2064.

Dunkle, S.A., Plummer, L.N., Busenberg, E., Phillips, P.J., Denver, J.M., Hamilton, P.A., Michel, R.L., Coplen, T.B., 1993, Chlorofluorocarbons $\left(\mathrm{CCl}_{3} \mathrm{~F}\right.$ and $\left.\mathrm{CCl}_{2} \mathrm{~F}_{2}\right)$ as dating tools and hydrologic tracers in shallow groundwater of the Delmarva Peninsula, Atlantic Coastal Plain, United States: Water Resources Research, v. 29, no. 12, p. 3837-3860.

Fleck, W.B., and Vroblesky, D.A., 1996, Simulation of ground-water flow of the Coastal Plain aquifers in parts of Maryland, Delaware, and the District of Columbia: U.S. Geological Survey Professional Paper 1404-J, 41 p.

Harbaugh, A.W., 1990, A computer program for calculating subregional water budgets using results from the U.S. Geological Survey Modular three-dimensional finite-difference ground-water flow model: U.S. Geological Survey OpenFile Report 90-392, 24 p.

Harbaugh, A.W., 2005, MODFLOW-2005, The U.S. Geological Survey modular ground-water model-The groundwater flow process: U.S. Geological Survey Techniques and Methods, book 6, chap. 16, variously paged.

Heywood, C.E., and Pope, J.P., 2009, Simulation of groundwater flow in the Coastal Plain aquifer system of Virginia: U.S. Geological Survey Scientific Investigations Report 2009-5039, $115 \mathrm{p}$.

Hill, M.C., Tiedeman, C.R., 2007, Effective groundwater model calibration: Hoboken, N.J., John Wiley \& Sons, $455 \mathrm{p}$.

Homer, C., Huang, C., Yang, L., Wylie, B., and Coan, M., 2004, Development of a 2001 national land-cover database for the United States: Photogrammetric Engineering and Remote Sensing, v. 70, no. 7, p. 829-840.

Kenny, J. F., Barber, N. L., Hutson, S. S., Linsey, K. S., Lovelace, J. K., and Maupin, M. A., 2009, Estimated use of water in the United States in 2005: U. S. Geological Survey Circular 1344, 52 p.

Langevin, C.D., Shoemaker, W.B., and Guo, W., 2003, MODFLOW-2000, the U. S. Geological Survey Modular Ground-Water Model-Documentation of the SEAWAT-2000 version with variable-density flow process (VDF) and the integrated MT3DMS transport process (IMT): U.S. Geological Survey Open-File Report 03-426, $43 \mathrm{p}$. 
Leahy, P.P., and Martin, M., 1993, Geohydrology and simulation of ground-water flow in the northern Atlantic Coastal Plain aquifer system: U.S. Geological Survey Professional Paper 1404-K, 81 p., 22 pls.

Niswonger, R.G., Panday, S., and Ibaraki, M., 2011, MODFLOW-NWT, A Newton formulation for MODFLOW-2005: U.S. Geological Survey Techniques and Methods book 6, chap. A37, 44 p.

Owens, J.P., and Denny, C.S., 1979, Upper Cenozoic deposits of the central Delmarva Peninsula, Maryland and Delaware: U.S. Geological Survey Professional Paper 1067-A, variously paged.

Phillips, S.W., and Lindsey, B.D., 2003, The influence of groundwater on nitrogen delivery to the Chesapeake Bay: U.S. Geological Survey Fact Sheet FS-091-03, 4 p.

Poeter, E.P., Hill, M.C., Banta, E.R., Mehl, S., and Christensen, S., 2005, UCODE_2005 and six other computer codes for universal sensitivity analysis, calibration, and uncertainty evaluation: U.S. Geological Survey Techniques and Methods, book 6, chap. A-11, 283 p.

Pollock, D.W., 1994, User's guide for MODPATH/MODPATH-PLOT, version 3: A particle tracking post-processing package for MODFLOW, the U.S. Geological Survey finite-difference ground-water flow model: U.S. Geological Survey Open-File Report 94-464, variously paged.

Reilly, T.E., Plummer L.N., Phillips, L. J, and Busenberg, E., 1994, The use of simulation and multiple environmental tracers to quantify groundwater flow in a shallow aquifer: Water Resources Research, v. 30, p. 421-433.
Reilly, T.E., and Pollock, D.W., 1996 Sources of water to wells for transient cyclic systems: Ground Water, v. 34, no. 6, p. 979-988.

Sanford, W.E., 2002, Recharge and groundwater models-An overview: Hydrogeology Journal, v. 10, no. 1, p. 110-120.

Sanford, W.E., 2011, Calibration of models using groundwater age: Hydrogeology Journal, v. 19, no. 1, p. 13-16.

Sanford, W.E., Nelms, D.L., Pope, J.P., and Selnick, D.L., 2012, Quantifying components of the hydrologic cycle in Virginia using chemical hydrograph separation and multiple regression analysis: U.S. Geological Survey Scientific Investigations Report 2011-5198, 152 p.

Sanford, W.E., and Pope, J.P, 2007, A simulation of groundwater discharge and nitrate delivery to the Chesapeake Bay from the lowermost Delmarva Peninsula, in Sanford W., Langevin, C., Polemio, M., and Povinec, P. (eds.), A New Focus on Groundwater-Seawater Interaction: IAHS Publication 312 , p. 326-333.

Sanford, W.E., Pope, J.P., and Nelms, D.L., 2009, Simulation of groundwater-level and salinity changes in the Eastern Shore, Virginia: U.S. Geological Survey Scientific Investigations Report 2009-5066, 125 p. 



\section{$\frac{2}{2}$}

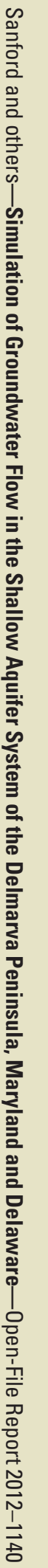

6 Printed on recycled paper

ISBN 978-1-4113-3508-0 